\title{
Por entre as grades: Um estudo sobre o cotidiano de uma prisão feminina
}

\author{
(VERSÃO ORIGINAL)
}

Dissertação apresentada ao Instituto de Psicologia da Universidade de São Paulo como parte dos requisitos para a obtenção do grau de Mestre em Psicologia.

Área de Concentração:

Psicologia Social

Orientador:

Prof. Dr. Paulo de Salles Oliveira 
AUTORIZO A REPRODUÇÃO E DIVULGAÇÃO

TOTAL OU PARCIAL DESTE TRABALHO,

POR QUALQUER MEIO CONVENCIONAL

OU ELETRÔNICO, PARA FINS DE ESTUDO E

PESQUISA, DESDE QUE CITADA A FONTE.

Catalogação na publicação

Biblioteca Dante Moreira Leite

Instituto de Psicologia da Universidade de São Paulo

Buckeridge, Fernanda Cazelli.

Por entre as grades: um estudo sobre o cotidiano de uma prisão feminina / Fernanda Cazelli Buckeridge; orientador Paulo Salles de Oliveira. -- São Paulo, 2011.

$112 \mathrm{f}$.

Dissertação (Mestrado - Programa de Pós-Graduação em Psicologia. Área de Concentração: Psicologia Social) - Instituto de Psicologia da Universidade de São Paulo.

1. Mulheres 2. Presos 3. Sistema penitenciário 4. Cotidiano 5. Memória 6. Narrativas I. Título. 


\section{Por entre as grades: Um estudo sobre o cotidiano de uma prisão feminina}

FERNANDA CAZELLI BUCKERIDGE

Orientador

PROF. DR. PAULO DE SALLES OLIVEIRA

Banca Examinadora

(nome e assinatura)

(nome e assinatura)

(nome e assinatura)

Dissertação defendida e aprovada em: 
Aos meus avós Mario e Edith Buckeridge e Alan e Elcy Cazelli, com quem aprendi a arte de não me conformar diante das injustiças e do sofrimento humano, mantendo vivas a esperança e a busca por um mundo melhor. 


\section{Agradecimentos}

Agradeço a meu orientador Prof. Dr. Paulo de Salles Oliveira pelo acompanhamento atento e próximo de meu percurso como pesquisadora, pela paciência nos momentos em que a escrita era difícil e em especial quando optei pela mudança do tema a estudar. Suas orientações e apontamentos foram essenciais nos momentos de definição dos rumos desta pesquisa, mantendo em perspectiva os prazos da pós-graduação.

Agradeço aos professores doutores Arley Andriollo e Yara Maria de Carvalho pela leitura cuidadosa e pelas sugestões preciosas na ocasião de meu exame de qualificação, que consideraram as potencialidades e as restrições diante do objeto de estudo escolhido, assim como o tempo de que dispunha para concluir o trabalho.

Aos professores doutores Ecléa Bosi, José Moura Gonçalves Filho, Gilberto Safra e Marcos Cesar Alvarez por suas aulas inspiradoras na graduação e na pós-graduação que contribuíram intensamente para minha formação profissional, intelectual e pessoal.

A Lenira Politano, Branca Paperetti, Graziela Acquaviva e Maria Elisa Braga, que me apresentaram às discussões sobre gênero e a condição da mulher e carinhosamente me acompanharam nos primeiros passos profissionais, minha eterna gratidão. 
Agradeço às minhas colegas e amigas Natalia, Flavia, Carla, Carina, Vanessa, Bruna e Elen, que trabalharam comigo realizando oficinas junto às mulheres presas apresentadas neste texto. Partilhamos momentos de cansaço, sentimentos de impotência, mas também risadas, companheirismo e esperança no trabalho que realizávamos. Conviver com vocês diariamente foi uma experiência, sem dúvida, inesquecível e de que guardo muitas saudades. Agradeço ainda a Luciana e Regina, por sua presença suave enquanto lidávamos com questões tão duras, e a Denise, Heidi e Michael, que concordaram em liberar-me por algumas horas na semana de trabalho para que eu cursasse as disciplinas da pós-graduação.

Agradeço a Maria de Lourdes Caleiro Costa por sua escuta compreensiva às minhas angústias, dúvidas e aflições durante todo o curso de pós-graduação, me auxiliando a encontrar caminhos em meio à profusão de questões suscitadas.

Aos meus amigos antigos e recentes, em especial Marcio Berber, Luís Fernando Saraiva, Andrea Almeida e Camila Milaré, pelos encontros e conversas que aliviavam a sensação de solidão, pelo seu suporte e paciência nos momentos em que eu me desesperava e naqueles em que eu precisei me ausentar. Vocês fazem e sempre farão parte da minha vida, de minha história e de quem sou.

Aos meus pais José Mario Buckeridge e Elaine Cazelli, cuja presença e compreensão foram fundamentais neste processo, obrigada pelo apoio e incentivo que sempre me deram e por acreditarem em mim mesmo quando minhas escolhas pareciam temerárias ou arriscadas. Agradeço ainda ao meu irmão Fabio Buckeridge que, apesar da distância física, se fez presente de várias formas, como leitor dos meus textos, interlocutor e motivador durante estes anos.

Por fim, agradeço a todas as mulheres presas que participaram desta pesquisa, com quem pude muitas vezes estabelecer vínculos de amizade, reconhecimento e respeito. Pudemos juntas muitas vezes resgatar o prazer de estarmos com os outros e sermos quem somos. A elas que me mostraram o que é resistir diante de situações adversas e encontrar vida e alegria mesmo onde esta busca parece difícil. 
"Desconfiai do mais trivial,

$\mathrm{Na}$ aparência singelo.

E examinai, sobretudo, o que parece natural.

Em tempo de desordem sangrenta,

De confusão organizada,

De arbitrariedade consciente,

De humanidade desumanizada,

Nada deve parecer natural,

Nada deve parecer impossível de mudar.”

— Bertold Brecht 


\section{Resumo}

BUCKerIDge, F. C. Por entre as grades: um estudo sobre o cotidiano de uma prisão feminina. 2011. 112 f. Dissertação (Mestrado) - Instituto de Psicologia, Universidade de São Paulo, São Paulo, 2011.

O presente estudo teve como objetivos traçar um panorama do cotidiano vivido dentro de uma penitenciária feminina do estado de São Paulo e mostrar um olhar interior sobre a condição da mulher encarcerada. O trabalho baseou-se na experiência vivida pela pesquisadora enquanto exercia a função de psicóloga junto a uma organização não governamental que realizava oficinas temáticas dentro de penitenciárias femininas paulistas. Procurou-se na perspectiva da psicologia social, delinear questionamentos e compartilhar reflexões produzidas na vivência com as presas, assim como realizar tentativas de elaboração teórica destes. Foram referenciais teóricos neste trabalho principalmente as obras de Wright Mills, Simone Weil, Hannah Arendt e Ecléa Bosi. Foram recursos nesta pesquisa principalmente os conteúdos de cartas redigidas por mulheres internas nesta unidade prisional bem como registros de informações coletadas, situações vividas, observações e falas ocorridas no dia a dia da instituição.

Palavras-chave: Mulheres, Presos, Sistema penitenciário, Cotidiano, Memória, Narrativas. 


\begin{abstract}
BUCKERIDGE, F. C. Through the prison bars: a study on the daily life of a female prison. 2011. 112 f. Dissertation (Master’s degree) - Institute of Psychology, University of São Paulo, 2011.

This study aimed to draw a broad view of the daily living within a female prison in the state of São Paulo and illustrate an insider's perspective of the condition experienced by the incarcerated woman. The study was based on the researcher's experience whilst working as a psychologist alongside an NGO that carried out thematic workshops in female penitentiaries located in São Paulo. From a social psychology perspective, the aim was to outline the raised questioning and share the thoughts created whilst being in the presence of the prisoners, as well as attempting to develop the theory of such questioning and thoughts. The works of Wright Mills, Simone Weil, Hannah Arendt and Ecléa Bosi were referenced throughout this study. The resources used in this research were mainly the contents of letters written by women inside this prison unit, in addition to information records collected, actual lived situations, comments and everyday conversations that occurred on the day-to-day of the institution.
\end{abstract}

Keywords: Women, Prisoners, Prison system, Daily life, Memory, Narratives. 


\section{SUMÁRIO}

INTRODUÇÃo 11

CAPÍtUlo 1 CENAS Do COTIDIANO 23

1.1 O dia-a-dia dentro da penitenciária 23

1.2 Uma figura esquecida no cenário prisional:

as agentes penitenciárias $\quad 44$

CAPÍTULO 2 OS RELACIONAMENTOS INTERPESSOAIS NO CÁRCERE 49

2.1 Os problemas e as queixas mais comuns 49

2.2 A constante queixa sobre o sentimento de solidão no dia a dia 61

2.3 A solidariedade possível 67

2.4 Amizade: possibilidades e restrições $\quad 74$

CAPÍTUlO 3 AS NARRATIVAS DE HISTÓRIAS DE VIDA E AS CARTAS 79

3.1 Narrativas e revelações $\quad 79$

3.2 O caminho percorrido pela pesquisadora rumo a outro nível de proximidade 87

3.3 Sobre as cartas recebidas $\quad 91$

PALAVRAS FINAIS 100

REFERÊNCIAS 109 


\title{
INTRODUÇÃo
}

\author{
Este é o tempo \\ Da selva mais obscura \\ Até o ar azul se tornou grades \\ E a luz do sol se tornou impura \\ Esta é a noite \\ Densa de chacais \\ Pesada de amargura \\ Este é o tempo em que os homens renunciam. \\ - Sophia de Mello Breyner Andresen
}

\begin{abstract}
De tanto ver, você não vê. O hábito suja os olhos e lhes baixa a voltagem. (...) Nossos olhos se gastam no dia-a-dia, opacos. É por aí que se instala no coração, o monstro da indiferença. - Otto Lara Resende ${ }^{1}$
\end{abstract}

Esta pesquisa se propõe, na perspectiva da psicologia social, a realizar reflexões acerca do cotidiano de uma unidade prisional feminina do estado de São Paulo a partir de cartas enviadas por mulheres presas e de observações, experiências e informações coletadas ao longo de meu exercício da função de psicóloga junto a uma organização não governamental. Nesta instituição, o trabalho consistia principalmente em realizar oficinas temáticas dentro de penitenciárias femininas na cidade de São Paulo. Gostaria, entretanto, de inicialmente convidar o leitor a conhecer os caminhos que fui trilhando como pesquisadora, descrevendo de que maneira a pesquisa foi se desenvolvendo de modo a se configurar nos moldes aqui apresentados.

Quando do meu ingresso no programa de pós-graduação em psicologia social, eu havia apresentado inicialmente um projeto de pesquisa com um tema diferente deste que agora se apresenta: desejava estudar quais os sentidos possíveis de serem produzidos por adultos que houvessem buscado retomar sua própria história familiar, através de narrativas de idosos (com quem compartilhassem uma mesma história familiar, sendo este parente ou não). Ao passar a 
me dedicar a este tema, tomei um rumo aparentemente diferente daquele que vinha traçando ao longo de toda a minha formação, vinculado a estudos de Gênero e Violência.

O interesse por esse tema surgiu por uma confluência de acontecimentos, tanto em minha vida pessoal como em observações na minha prática profissional como psicoterapeuta, em especial desde o final do ano de 2006. Iniciando minha carreira, observava com bastante espanto a frequência com que pessoas recorriam à psicoterapia com o diagnóstico - 'auto-realizado’ ou não - de depressão. Havia queixas frequentes sobre a perda do interesse e motivação para viver, sentimentos de desenraizamento, solidão, vazio e falta de sentido existencial e escassez e fragilidade dos laços afetivos, todas essas vivências muitas vezes referidas apenas a falhas individuais pela não correspondência aos ideais de sucesso vigentes em nossa cultura. Os eventos disparadores de angústias e sofrimento ficavam incrustados apenas no presente: não podiam ser contextualizados ou compreendidos na história dos sujeitos, dificultando pensar e planejar o futuro e a realização da 'costura' de presente, passado e futuro, configurando uma noção de temporalidade onde parecia haver apenas o presente angustiante. Interessava-me portanto pensar a questão dos modos de subjetivação promovidos na sociedade contemporânea - na qual as questões relativas à historicidade, temporalidade e memória adquirem grande relevância - e as narrativas das histórias de vida como uma possibilidade de rompimento com o isolamento em que vivem muitos sujeitos atualmente. Ao fazer reviver vozes e imagens, estas se apresentam como um modo de ir alinhavando os fios da existência, dando sentido às experiências vividas, reterritorializando o vivido, reafirmando o vínculo do sujeito com suas interações com o mundo, delineando um passado e um contexto existencial, e criando um campo para o encontro com a alteridade. Seriam estas tentativas dos sujeitos de desenvolver pontes entre um relato individualizado e uma construção histórica no coletivo?

Durante este período, por opção minha, continuei também trabalhando em paralelo aos estudos do mestrado e, passados seis meses de meu ingresso no programa de pós- 
-graduação, iniciei um trabalho em uma organização não-governamental sediada em São Paulo. Esta instituição, na qual trabalhei como psicóloga realizando oficinas, atua há alguns anos na defesa dos direitos dos cidadãos, tendo desde o início como seu principal campo de ação as penitenciárias femininas da cidade de São Paulo. Minha participação junto a esta ong se deu por meio de um de seus projetos, que tinha como objetivo proporcionar um espaço de reflexão e vivência de participação junto às mulheres que estão presas, através de oficinas temáticas cujos eixos principais tinham como temas a violência, gênero e cidadania. Eram também aplicados questionários individuais que buscavam contribuir para o delineamento do perfil da mulher presa em São Paulo. Havia ainda esforços no sentido de fomentar o debate acerca das prisões femininas, detectando e apontando demandas e problemáticas neste contexto, e contribuir para a multiplicação de trabalhos neste campo.

Este projeto realizou trabalhos em diversas instituições carcerárias do estado e objetivava ampliar sua atuação do projeto para o sistema penitenciário como um todo, realizando esforços para iniciar também um trabalho junto às agentes penitenciárias, que também faziam parte da comunidade carcerária e, portanto, comungavam dos sofrimentos inerentes à própria dinâmica da instituição. Essa experiência me auxiliava a manter uma visão mais ampla das questões, evitando classificações maniqueístas redutoras da realidade.

Em uma dentre estas unidades prisionais assistidas, o trabalho encontrava mais receptividade por parte da instituição, pois na época contava com poucas atividades a oferecer diante do grande número de internas que abrigava. Essa característica me possibilitou ter contato com um maior número de mulheres nessa penitenciária e por um período mais prolongado, acompanhando sua rotina e seu cotidiano. É por este motivo que este trabalho irá se debruçar principalmente sobre as experiências vividas neste espaço.

Trabalhar dentro das unidades prisionais não fora previamente planejado, mas se revelou uma experiência fértil em diversos aspectos. As vivências, as situações observadas, o 
contato com as pessoas e suas histórias que passavam a fazer parte do meu cotidiano me mobilizavam afetivamente e intelectualmente, florescendo em questionamentos e em aprendizados enriquecedores para mim, como técnica e também como pesquisadora.

É notório que o tema da violência e da criminalidade vem atualmente ganhando crescente destaque na mídia nos debates e conversas do dia a dia das pessoas. Observamos que em geral há o aval da sociedade brasileira à pena de privação de liberdade e até mesmo a reivindicação fervorosa de medidas punitivas mais rígidas e o combate à impunidade. Ao mesmo tempo, contraditoriamente, convive com um discurso que se pretende pautado pelos direitos humanos e pela justiça e que reconhece a ineficácia da pena de prisão em sua atribuída função de recuperação dos criminosos e redução da violência e da criminalidade. Ao iniciar este trabalho na penitenciária, observava que estas mesmas contradições apareciam nos discursos, ações e opiniões proferidas por funcionários, técnicos e até mesmo pelas mulheres presas, e que isso afetava de muitas maneiras seus relacionamentos interpessoais.

Também nas falas e ações institucionais, notávamos que estas prisões femininas observadas pareciam comportar simultaneamente duas formas de regime. Um deles era o regime disciplinar como detectado por Foucault (1993) em Vigiar e Punir, pois mantinham como características em seu discurso a responsabilização individual das detentas, como objetivo da instituição as propostas de correção e reabilitação, e o delineamento dos comportamentos aceitos e reprovados na sociedade através da punição daquelas que apresentassem as ações indesejadas. Ao mesmo tempo, observávamos também que um outro modelo parecia ganhar espaço: o regime atuarial como descrito por De Giorgi (2006). Este também estava presente, pois as estratégias de segurança e as instituições prisionais pareciam voltadas maciçamente para os estratos mais pobres e privados de direitos básicos, o que leva a criminalização da miséria e a circunscrição dos riscos e sua gestão a populações tidas como "classes perigosas". Diferentemente do modelo Foucaultiano - no qual o controle disciplinar constituía-se sobre um poder-saber sobre 
o corpo e os indivíduos, assim como sobre as formas de interação e cooperação a que deveriam ser submetidos - o modelo proposto por De Giorgi descreve a renúncia a qualquer saber sobre os indivíduos. Abre-se mão da individualização pontual e precisa, como ocorria no regime disciplinar - que visava delinear o perfil do criminoso e consequentemente as formas eficazes necessárias para a sua correção -, e passa-se a exercer como mecanismo de controle uma função de supervisão e contenção preventiva de classes inteiras de sujeitos, reagrupando a diversidade nas já citadas "classes perigosas". Deste modo, a gestão das populações problemáticas passam a ocorrer cada vez menos por instrumentos de regulação social da pobreza e cada vez mais por dispositivos de repressão penal, apontando para a transição da vigência de um Estado Social para um Estado Penal. Na medida em que esta racionalidade atuarial do controle se impõe, não mais se trataria de prender indivíduos criminosos perigosos, mas de gerir ao nível de populações inteiras uma carga de risco que não encontra formas de ser reduzida.

A população carcerária estudada é composta majoritariamente por mulheres jovens, pobres, negras e pardas, pessoas com histórias de vida marcadas pela miséria e pela negligência estatal que provavelmente compartilham históricos de desigualdade e humilhação bastante semelhantes, levando-se em consideração os signos de classe social, gênero e cor que carregam. Em conversas particulares, nos corredores, em colocações em grupos, por cartas - de várias formas me chegavam histórias de mulheres que relatavam histórias de sofrimento e humilhações anteriores ao evento de suas prisões, nas quais não tiveram voz ou não foram ouvidas e levadas em conta como cidadãs, em que seu sentimento de dignidade fora desfeito no contínuo contato com situações de rebaixamento e descaso. Esta era uma experiência compartilhada por mulheres presas e por muitos dos funcionários e agentes penitenciárias, ainda que houvessem realizado escolhas diferentes - ao menos a princípio - diante da criminalidade e da honestidade. Não raras vezes estes advinham das mesmas regiões da capital paulista e tinham referências culturais e sociais semelhantes às das presidiárias, utilizando as mesmas expressões, gírias e gestos. 
Acompanhando o cotidiano prisional, ouvia no convívio com as internas queixas de diversas ordens, havendo uma mais frequente e comum entre elas. Confinadas em um mesmo espaço apesar de ali chegarem com idades, histórias, opiniões e graus de envolvimento com o crime bastante diversos, viam-se obrigadas a conviver em proximidade por longos períodos de tempo. Entretanto, apesar desta proximidade de natureza física, relatavam um grande distanciamento nos relacionamentos interpessoais. Queixavam-se bastante pela percepção de que as relações interpessoais são pautadas pelo 'cada um por si' e que o valor de cada pessoa era dado pelos bens materiais e o poder que detém dentro da cadeia. Esses contatos interpessoais, diziam elas, eram mediados constantemente por relações de troca, de modo que raramente algo era feito em prol do outro sem que houvesse algum benefício direto associado a esta ação. Mesmo a reivindicação de direitos ocorria de modo individualista e auto-centrado. Deste modo, aquelas que não contam com bens materiais ou alguma forma de poder têm pouca força de troca, passando assim por muito mais dificuldades em relação às que contam com estes benefícios. Isto fazia com que experimentassem grande isolamento, solidão, insegurança e receio em desenvolverem entre si laços afetivos e de confiança.

A presença da facção criminosa hegemônica também contribuía para esta problemática: havia de fato o perigo em manifestar opiniões e expor experiências pessoais, pois estes poderiam ser interpretados como uma manifestação de oposição ou até mesmo tornarem-se informação a ser usada em seu prejuízo. Além da restrição à liberdade de expressão destas mulheres, havia também a ideologia que propagava e que incentivava a competição e a desconfiança, sendo reiterada a todo o momento através de regras e hierarquias internas repetidas por elas nos corredores. Ferreira (2006), desenvolvendo sua reflexão acerca da relação entre a comunidade e o que chama de crime organizado, bem descreve esta lógica ao nos dizer que as regras deste último “(...) são os princípios mercantis levados ao paroxismo: o desejo de ganho, dinheiro 
e mercadorias, competição desmedida e o interesse individual acima de qualquer consideração, da lei, das vidas".

Este regime de desconfiança universal dificultava o reconhecimento recíproco destas mulheres como parte de uma mesma força de trabalho social, as afastava e se fazia obstáculo para que pensassem coletivamente os problemas que vivenciavam juntas. Isto colaborava para um entendimento da experiência da prisão como resultado apenas de falhas individuais e de deficiências de caráter pessoais.

As queixas do isolamento e do sentimento de solidão compartilhadas por muitas das internas - e frequentemente eleitas dentre tantas outras possíveis no contexto prisional nos dava a pensar sobre a importância dos vínculos interpessoais e do sentimento de pertinência social, seja em sua dimensão subjetiva e intersubjetiva, como em sua dimensão política e cívica. Estas surgiam intensamente como demanda dentro do cárcere, mas também diziam algo da cultura na qual este está inserido.

Nesse contexto havia ainda muitas mulheres que buscavam participar de atividades em grupo que não ofereciam nenhum benefício direto em troca - como por exemplo a remição de pena ou o recebimento de salário - como no caso das atividades realizadas pela ong em que trabalhei, da escola ou dos trabalhos, por livre e espontânea vontade. Observava também que em alguns casos a amizade e o companheirismo eram possíveis, tornando-se lugar seguro para encontrar conforto e reencontrar suas identidades pessoais, compartilhando sonhos e reflexões, ouvindo e contando suas histórias de vida. Apesar das queixas de solidão que apresentavam e dos estigmas de maldade, falta de caráter e periculosidade comumente atrelados às presidiárias identificados nos discursos tanto de quem as vê de fora e de funcionários da penitenciária como muitas vezes no das próprias presas -, encontrávamos no cotidiano eventuais demonstrações de solidariedade, empatia e desejo de demonstrar e receber afeto. 
No dia a dia dos corredores e pavilhões, pude aos poucos conhecê-las mais de perto, e as presas iam ganhando rosto, nome e história. Sentia cada vez mais a necessidade de constantemente conciliar em uma mesma pessoa os comportamentos doces e hospitaleiros que apresentavam, com histórias de crimes e algumas vezes a capacidade de cometer violências inimagináveis que relatavam. Em meio a histórias sofridas e dores presentes compartilhadas, para além dos papéis que ali sustentávamos, um outro nível de envolvimento começava a tomar lugar, passando a cada vez mais se permitirem expressar emoções, rever e narrar memórias de vida. Nestas, muitas vezes escolha e determinação se confundiam, pois ao mesmo tempo em que havia posicionamentos pessoais, estes eram tomados diante de alternativas muito restritas. As opções entre crime ou honestidade que pudessem ter feito pareciam ambas fundamentadas no mesmo desejo intenso por reconhecimento e restabelecimento da dignidade.

A partir dos vínculos que construímos, recebi e respondi cinco cartas escritas por quatro mulheres (duas das cartas escritas por uma mesma presa): Ana, Jussara, Mariana Thomas e Isabel. Estas cartas que muito me emocionaram pareciam representar em suas palavras tanto aspectos singulares de cada remetente como também questões compartilhadas por outras mulheres que conheci naquela prisão. Elas me falavam de seu cotidiano muitas vezes violento e repetitivo, mas que também era permeado por contatos significativos e pela solidariedade. Buscavam saber notícias da vida que corria fora da penitenciária, manifestavam saudades e gratidão e me enviavam seus desejos de proteção divina. Seus relatos dançavam entre o mero aguardo do término da pena e lampejos de esperança ao permitirem-se fazer novos planos para o futuro.

Foi em meio a estas percepções e questões suscitadas que a idéia para este trabalho foi concebida. Ciente das possíveis dificuldades que poderia encontrar em relação aos prazos da pós-graduação e mesmo à autorização de minha pesquisa por parte da instituição - questões estas cuidadosamente retomadas por meu orientador e discutidas em reuniões - escolhi dedicar meu estudo a este novo tema de dissertação. Permaneceria o interesse pelas problemáticas do 
desenraizamento, das narrativas, da construção de sentidos, de pertença e coletividade. Entretanto, outros pontos que antes não se colocavam de modo central surgiram, como a violência, a desigualdade social, o controle social, as instituições totais, entre outras.

A princípio elaborei um projeto acerca do estudo sobre as vivências das mulheres encarceradas nesta penitenciária localizada no estado de São Paulo, sobre o modo como percebem a si próprias e às pessoas à sua volta. A pesquisa buscaria abordar o tema através do recurso à memória das mulheres, através de entrevistas semi-dirigidas, e de seus relatos autobiográficos. O recurso às narrativas autobiográficas visava a que o próprio processo de pesquisa refletisse sua concepção teórica: as biografias e autobiografias como fenômenos tecidos por iniciativas e o narrar como possibilidade de elaboração de experiências e sofrimentos individuais e coletivos e revelação de sentidos. Lembrando a citação de Isak Dinesen que abre o capítulo sobre a Ação no livro de Arendt (2008) A condição humana, "todas as mágoas são suportáveis quando fazemos delas uma história ou contamos uma história a seu respeito".

Marquei então uma reunião com uma das diretoras de educação da penitenciária para conversarmos sobre a possibilidade de realizar a pesquisa nesta instituição. Neste encontro, entreguei a ela o pré-projeto de minha pesquisa e esclareci que a proposta do trabalho não seria a de realizar críticas - ainda que apontamentos críticos pudessem ser feitos - e ataques à instituição, mas de estudar o cotidiano das mulheres na penitenciária com todas as suas contradições, inclusive considerando o sofrimento de funcionários e as suas perspectivas e opiniões.

Estando de acordo com a realização da pesquisa, a diretora explicou que o projeto precisaria primeiramente passar pela aprovação do diretor geral e, com seu aval, ser enviado então para a SAP (Secretaria de Administração Penitenciária do Estado de São Paulo). Dei entrada então com um pedido de autorização para a realização da pesquisa no início de janeiro de 2009. A autorização do diretor geral levou aproximadamente dois meses para ocorrer e foi então encaminhada para a avaliação da SAP. Por fim, a autorização da SAP foi concedida oito meses após a 
entrada de meu pedido, no início de agosto de 2009, momento em que a pesquisa infelizmente não mais poderia ser realizada na forma como fora proposta, dentro do prazo ainda disponível. Tendo esta tramitação se alongado demasiadamente, antes mesmo de receber a notícia da autorização, por sugestão de meu orientador outra abordagem metodológica para o tema foi elaborada e tomou o lugar da anterior, a partir das possibilidades existentes diante das restrições de tempo impostas por minha escolha pela mudança do tema de pesquisa e pelas características do próprio objeto de estudo enquanto instituição total - suas especificidades, burocracias e entraves à aproximações e visibilidade. Nesta outra abordagem, optou-se por realizar a pesquisa baseada na experiência que vivi trabalhando com grupos de mulheres presas nesta penitenciária feminina do estado de São Paulo, a partir principalmente do conteúdo das cartas recebidas como recurso central nesta pesquisa - como sugerido, dentre outros valiosíssimos apontamentos realizados, pelos membros da banca na ocasião de meu exame de qualificação. Recorri também a anotações realizadas na forma de um diário de campo acerca de observações, falas e reflexões ocorridas no dia a dia da instituição.

Este estudo teve como objetivos traçar um panorama do cotidiano vivido dentro de uma penitenciária feminina e mostrar um olhar interior sobre a condição da mulher encarcerada. Visando a preservar todos os envolvidos nesta pesquisa, não serão citados nomes da instituição, da ONG e das mulheres apresentadas neste trabalho, sendo estas últimas tratadas por nomes fictícios. Tendo em perspectiva que a proposta da pesquisa é a de levantar questionamentos e compartilhar reflexões produzidas na experiência vivida com as mulheres presas, assim como realizar tentativas de elaboração teórica desta, a explicitação desses dados não se faz estritamente necessária, não se configurando neste trabalho como objeto primeiro do estudo.

Procuramos neste trabalho organizar os capítulos centralizando os textos nas cartas e falas das internas bem como nas observações do cotidiano, desenvolvendo as reflexões e elaborações teóricas a partir de uma análise posterior ao contato com as mulheres e seu dia a 
dia, reproduzindo assim o caminho percorrido ao longo da própria pesquisa. No capítulo 1, “Cenas do cotidiano", aberto por um trecho da carta de Isabel, procuramos descrever o ambiente, desde a entrada da penitenciária estudada até o pavilhão onde as internas permaneciam grande parte do tempo, as atividades que desenvolviam, os primeiros contatos com as mulheres e as formas de aproximação realizadas. Além disto, apresentamos também outros personagens da comunidade carcerária tais como os funcionários e agentes penitenciários. Ainda que tenhamos tido pouco contato direto com estes últimos, este trabalho se dedicará brevemente a considerar e refletir acerca de sua condição, apresentando as questões levantadas junto a eles e esboçando algumas discussões que possam ser estudadas futuramente.

O capítulo 2, "Os relacionamentos interpessoais no cárcere", tem como abertura os trechos das cartas de Ana e de Jussara e trata tanto do impacto do evento da prisão para os relacionamentos interpessoais que estas mulheres mantinham antes da prisão com a família, companheiros, amigos e vizinhos, como também dos modos como se relacionavam entre si na penitenciária, a partir das queixas mais comuns que apresentavam no dia a dia. Apresentamos também um breve panorama do perfil da mulher presa no Brasil e da implicação de questões de gênero nos problemas apresentados. Neste capítulo, abordo ainda a queixa principal trazida a mim pelas presidiárias sobre o sentimento de solidão e dificuldade em estabelecerem vínculos de confiança no cárcere, buscando compreender algumas das determinantes envolvidas neste fenômeno. Por fim, descrevemos e discutimos as formas de solidariedade possíveis neste contexto, assim como o evento de vínculos de amizade entre elas.

O capítulo 3, "As narrativas de histórias de vida e as cartas", inicia-se com a transcrição de um trecho da primeira carta enviada por Mariana Thomas. Nele descrevo o percurso que realizei junto com as presas rumo a outro nível de proximidade, iniciado no contato propiciado pelas oficinas em grupo e pela aplicação de questionários individuais que realizei como representante da ONG - e desenvolvido para além destes espaços -, frutificando no comparti- 
lhamento de histórias de vida e culminando com a troca das cartas. Discuto os obstáculos que superavam de ordem material e subjetiva para possibilitar o ato de escrever uma carta e levanto algumas hipóteses acerca dos sentidos do estabelecimento desta forma de comunicação entre elas e eu. Apresento ainda o conteúdo destas últimas relacionando-o às questões discutidas anteriormente no texto e apontando o surgimento, em suas palavras, de manifestações de esperança e de planos para o futuro.

Nas palavras finais, retomarei as diversas questões e problemáticas levantadas nesta introdução e ao longo dos capítulos, procurando realizar a costura dos temas apresentados e propor caminhos a partir das reflexões feitas no texto.

Por fim, foram neste trabalho minhas principais referências teóricas neste trabalho as obras de Wright Mills, acerca da relação entre a biografia do pesquisador e o tema de pesquisa; de Simone Weil, em especial, seus conceitos de atenção e desenraizamento; de Ecléa Bosi, como concepção metodológica do estudo da memória, reflexões sobre a percepção e a sensibilidade diante das coisas que povoam nosso mundo, para além do óbvio e do já visto; e Hannah Arendt, principalmente em suas concepções acerca do trabalho, da mundanidade e do agir.

Foram ainda de extrema importância as interlocuções com autores como Paulo de Salles Oliveira e seus apontamentos sobre o estudo das experiências compartilhadas na vida cotidiana; Alessandro De Giorgi, Zygmunt Bauman e David Garland, e seus estudos sobre a punição, a prisão e os mecanismos de controle sociais; Richard Sennett e sua obra $A$ corrosão do caráter; Emmanuel Lévinas e sua concepções teóricas sobre a violência, o rosto e a responsabilidade ética diante dele; Margarida Mamede e seu trabalho com internas de um manicômio judiciário paulista; e Ana Maria Seraidarian e seus textos que tratavam dos sentidos das cartas como forma de comunicação solitária, mas que trazia em si o encontro. 


\title{
CAPÍtULO 1 \\ Cenas do cotidiano
}

\begin{abstract}
Mais um dia que se passa e outra tranca que se fecha, maritacas na janela. Observo da minha cela. Como são lindas! Que belas! Vejo, está escurecendo, quando me vejo estou com grades na janela. Porta trancada... certas horas. Escuridão, eu aqui na cela, não tem nenhuma distração. Amanhece novamente, ando. Procuro, não vejo nada aqui, existem só mulheres, desce e sobe nas escadas. Todo dia a mesma coisa, gritaria, falação, este lugar, amiga, ninguém merece (...).

Ser presa é ter grades como refém, é sentir o peso da solidão, é ter no coração a grande dor da saudade. É desejar algo e não poder, é desejar um dia de visita, aguardar a liberdade a cada dia, melhorar, mesmo que isto esteja longe de acontecer, é sentir na carne a dor do sofrimento num lugar escuro e sombrio, é a tristeza de um infinito que envolve os sentimentos mais sinceros, é ser prisioneira da mais pura separação, é sentir na pele a grande separação, é ver a distância dos olhos consumidos, pouco a pouco sugando, alimentados pelos poucos momentos de alegria que temos, é ser feliz por etapas.

- Trecho de carta de Isabel
\end{abstract}

\subsection{O dia-a-dia dentro da penitenciária}

A penitenciária feminina na qual realizei as observações apresentadas nesta pesquisa está localizada na capital do estado de São Paulo. De modo diverso ao que costuma ocorrer, não está situada em alguma região isolada, distante e de difícil acesso. Encontra-se em uma avenida bastante movimentada, próxima de centros comerciais, imóveis residenciais e avenidas importantes e movimentadas.

Ainda assim, a visada de seu exterior não a torna parte do cotidiano dos transeuntes e moradores da região ou uma problemática mais familiar a estes. A estrutura externa permanece a ocultar, distanciar o dia a dia que transcorre por trás de suas paredes, grades e portões. Podemos ver de fora deste complexo prisional de proporções excepcionais grandes muros em tons de cinza e bege que o circundam impedindo em grande parte o contato visual com o prédio, muitas árvores altas por trás destes muros que os ultrapassam em altura e um largo e alto portão 
de ferro principal, guardado por vigilantes, que vez ou outra abre-se para receber carros, viaturas, ambulâncias, caminhões e, em alguns casos, pessoas que chegam ao local a pé - este era o caso da equipe de trabalho da qual fiz parte. A passagem pelo portão principal com automóveis encontrava maior dificuldade se comparada com a encontrada pelos pedestres.

Antes da minha primeira visita à penitenciária, havia uma expectativa de que a minha entrada e os contatos iniciais com os funcionários e as internas pudessem ser mais difíceis - como costuma acontecer em qualquer espaço em que se acaba de chegar -, pois mesmo compondo uma equipe cujo trabalho já se realizava há bastante tempo, eu ainda não era um 'rosto conhecido', ainda era uma estranha. Por outro lado havia os fatores facilitadores de que o trabalho já havia conquistado alguma confiança da instituição e de que a equipe se apresentava ao local uniformizada - uma camiseta de cor roxa com o logotipo do projeto estampado à frente.

Pude observar que a camiseta do uniforme que usávamos apresentava uma função ambígua: ao mesmo tempo em que me integrou rapidamente à equipe e facilitou tanto a minha primeira entrada na unidade como as visitas subsequentes, também dificultava que uma relação mais pessoal ou de reconhecimento como indivíduo ocorresse, de modo que, quando comparecia sem a camiseta meu reconhecimento era menos comum, mesmo com a frequência e o tempo prolongados com que visitei a unidade.

A minha expectativa de que iria ocorrer uma aproximação gradual ao longo do tempo com as pessoas que trabalhavam ali não se confirmou da forma como havia imaginado. As passagens pelo portão principal - assim como em alguns outros portões e grades internos mantiveram algumas características comuns e independentes do período em que frequentei a unidade. Estas características poderiam ser identificadas como a desconfiança, o acesso dependente das relações estabelecidas pessoalmente com alguns funcionários e a imprevisibilidade, características estas a serem melhor esclarecidas a seguir. 
Ao adentrar a unidade prisional, temos a sensação clara de que não estamos em um local em que se possa agir descompromissadamente. Ainda que se tenha visitado a unidade por inúmeras vezes, a cada visita olhares e palavras nos lembram de que estamos lidando com autoridades e figuras que, ao menos dentro daquele ambiente, detêm alguma forma de poder e, portanto, devemos tomar cuidado com nossas palavras e deixar todas as nossas ações claras o suficiente para que não levantem suspeitas. Deste modo, a entrada na penitenciária quase sempre é permeada por este sentimento de desconfiança, independentemente da relação de médio a longo prazo já estabelecida com a instituição.

Outro fator que interfere no acesso ao complexo prisional é a dependência deste em relação aos contatos pessoais estabelecidos com alguns funcionários, assim como seus posicionamentos particulares quanto ao seu trabalho, os sentidos que atribuem à prisão e às atividades lá realizadas com as mulheres internas. Ainda que para obter o acesso seja necessário passar por procedimentos burocráticos prévios para obter a autorização da diretoria da unidade - através de ofícios por correio eletrônico com determinado tempo de antecedência -, podemos ainda encontrar algumas dificuldades que ocorrem na entrada e vão desde a demora na liberação do acesso, ocasionando atrasos - através de lenta revista de materiais, dos profissionais e seus registros com documento de identidade, mudanças de procedimentos, como não aceitação, naquele dia especificamente, do ofício enviado exigindo a confirmação por telefone com a diretoria, entre outros - até o cancelamento da visita e impedimento do acesso, caso o ofício não houvesse sido entregue pela direção à portaria ou o representante da direção não estivesse presente para confirmar a autorização da visita por telefone. Havia profissionais que nos recebiam com bastante simpatia, com frequência lembrando o nome dos integrantes da equipe e mantendo o procedimento padrão e costumeiro, sem causar grandes problemas e dificuldades. No entanto, sendo este trabalho realizado por profissionais que se revezavam em turnos, não era possível supor como seríamos recepcionados quando chegássemos à penitenciária. 
Por fim, a imprevisibilidade citada acima se relaciona com os dois fatores anteriores já discutidos, mas também se dá em razão do cotidiano vivido dentro do complexo penitenciário e dos reflexos do 'clima' da instituição naquele momento. É possível que haja maior ou menor tensão entre os funcionários da penitenciária e as mulheres presas, ameaças de manifestações e rebeliões, questões políticas que possam ter reflexos para os profissionais, mudanças frequentes de representantes da direção e de cargos de comando, datas comemorativas que causam agitação entre as mulheres, casos polêmicos discutidos na mídia que remetem aos sentidos da prisão ou que envolvem a criminalidade, como prisões e julgamentos de representantes do crime organizado, entre outros. Deste modo, estando este cotidiano velado dentre os muros, não é possível prever como encontraremos a unidade não somente quanto à entrada, mas também quanto ao contato com as mulheres, funcionários e direção. Na entrada, mesmo o funcionário mais disposto a receber bem os visitantes pode estar sob altos níveis de estresse e preocupações naquele momento, interferindo nos procedimentos de recepção.

O primeiro portão raramente apresentava estas dificuldades ou impedimentos aos que entravam, exceto a relação de desconfiança, mas que raramente levava a vetar a entrada do pedestre. Cruzando-se este portão, podíamos ver um longo corredor aberto cercado por árvores, com alguns bancos de cimento e carros estacionados nas laterais.

No início deste corredor, vê-se lateralmente um pequeno quarto coberto no qual está escrito no topo com tinta a palavra 'Jumbo', ou seja, trata-se do local onde familiares e amigos entregam compras, objetos, roupas e alimentos que são destinados mensalmente às mulheres presas e denominados desta forma. Ao longo do corredor, caminham pessoas que visitam a unidade por diversos motivos: religiosos, advogados, parentes que buscam informações sobre alguma mulher que se encontre presa, funcionários que chegam e que vão embora com ou sem uniforme, entre outros. 
No final deste corredor há um muro alto pintado de amarelo, e nele outro grande e alto portão de ferro por onde passavam caminhões com carregamentos de alimentos e outros suprimentos, viaturas e ambulâncias, guardado por dentro por agentes penitenciários que trajam camisetas cinzas e pretas. Há portas também, e dentre estas se encontra a da sala de raio-X para objetos grandes que serão levados para dentro e a porta que é utilizada como entrada pelos visitantes. Nesta sala todos os objetos portados são revistados e passados no raio-x e é realizada a revista administrativa também das pessoas que entrarão, que passam por um detector de metais.

Ao ultrapassar este trecho do percurso, cruzamos então mais um portão de ferro, onde deixamos com um agente algum documento de identificação, e então somos autorizados a acessar o espaço onde se encontram os pavilhões e a parte administrativa do complexo. Ambos se localizam no mesmo prédio: olhando de frente, vemos uma entrada por escadas que dá acesso ao andar superior à área administrativa. A entrada da área administrativa é guardada pela seguinte frase inscrita na fachada do prédio: "Aqui o trabalho, a disciplina e a bondade resgatam a falta cometida e reconduzem o homem à comunhão social”. Abaixo, no andar térreo, vemos um portão com a entrada para os três pavilhões guardada por outro agente. Cada pavilhão tem cerca de quatro andares que ficam atrás da parte administrativa. O prédio guarda em sua estrutura muitas referências religiosas - como quadros com temáticas sacras, imagens de santos e crucifixos - e semelhanças com antigos colégios.

Ao redor dele é possível ver outros prédios assim apelidados: o 'Seguro', onde ficam alojadas mulheres que por algum motivo precisam ser isoladas das outras presas como medida de proteção a suas próprias vidas; o 'Castigo', onde permanecem por algum tempo as mulheres que cometeram infrações dentro da prisão; e a 'Inclusão', local onde permanecem por um período de dez a vinte dias as mulheres recém-chegadas para cumprir o chamado Regime de Observação (Rо). Funciona como um período de adaptação à penitenciária anterior à sua instalação dentro do pavilhão, no qual as reclusas passam por exames médicos e por entrevistas com 
psicólogos e assistentes sociais, que realizam um estudo psicossocial. As detentas são também informadas sobre as normas da unidade e sobre as ações passíveis de punição dentro da cadeia. Essas mulheres, quando são conduzidas ao pavilhão, passam a ser chamadas pelas internas e agentes como 'RO', tornando a sigla do regime um apelido para as recém-chegadas.

Há entradas laterais no prédio principal que dão acesso às entradas externas das escolas penitenciárias, fábricas e oficinas onde algumas mulheres presas estudam e trabalham. Neste espaço, podemos ver transitando agentes uniformizados com camisetas cinzas e pretas, profissionais da área administrativa que podem trajar-se à sua escolha, e também mulheres internas uniformizadas com camisetas brancas sem estampas e calças amarelas ou beges, estas últimas sempre realizando alguma função como a retirada de lixo dos prédios e transporte e distribuição da alimentação das mulheres presas (função chamada na prisão de 'Boia' ).

Ao adentrarmos o corredor que nos leva aos pavilhões, uma série de outros portões iam se abrindo e se fechando após a passagem. Havia a sensação de que, caso houvesse a necessidade de deixar aquele local, não seria prontamente atendida; esta escolha não estaria mais sob minha decisão e controle, mas nas mãos de outras pessoas desconhecidas a mim, portadoras das chaves. Sentimos que estamos realmente adentrando um espaço de intimidade, um espaço velado, privado, tanto na expressão dos agentes quanto na das mulheres, que olham com estranhamento as pessoas que não parecem ser nem agentes nem presas. Algumas reconhecem a camiseta com o logotipo e cumprimentam integrantes da equipe de modo bastante caloroso e afetivo, perguntando sobre os encontros e grupos. Alguns agentes também reconhecem o uniforme e, por conta disso, nos recebem com incentivos ao trabalho realizado, apresentando desde expressões faciais menos endurecidas e inquisitivas, até agentes que nos recebem com frieza, descrédito no propósito do trabalho e olhares de sarcasmo.

O ambiente é mais escuro e frio que os anteriores. O corredor é bastante longo e perpassa os três pavilhões. O teto do corredor é repleto de fios de energia elétrica expostos de 
forma bastante precária. Há inúmeras rachaduras no teto e nas paredes, evidenciando ser este um prédio bastante antigo e com poucas condições de permanecer em atividade. As paredes são todas pintadas de branco e azul, e vemos respingos de tinta por toda parte. No chão encontramos muitas poças de água, bueiros perto dos quais vemos baratas vivas e mortas, restos de comida e pontas de cigarro.

Nas laterais dos corredores há janelas com grades através das quais vemos os espaços entre os pavilhões. Nesses espaços ficam pátios para banho de sol, hortas, playgrounds. Podemos ver mulheres andando em círculos, mulheres sentadas, algumas conversando através de gritos pelas grades com outras do outro lado do corredor, fumando, penteando e pintando os cabelos, clareando os pelos das pernas, pendurando roupas lavadas. Há um ruído de vozes incessantes ecoando por todas as instalações.

Todos os pavilhões têm duas entradas, uma à esquerda e outra à direita do corredor principal acima descrito, chamados de lado par e lado ímpar, e agentes que registram entradas e saídas. Cada pavilhão pode ter suas entradas decoradas ou não, e a seu modo. Alguns o fazem em datas comemorativas, como o dia das mães e o Natal, utilizando pinturas e desenhos com cartolinas, papel crepom, lápis de cor e giz de cera. No andar térreo do pavilhão fica o corredor com as celas, chamadas pelas mulheres de 'xis' e que costumam alojar de duas a três mulheres, e fora do corredor, uma sala utilizada como enfermaria, onde encontramos quase sempre algumas mulheres sentadas e algumas cadeiras de rodas disponíveis. Para acessar o espaço no qual fica o plantão com os agentes penitenciários e os corredores radiais entre os pavilhões, é necessário subir até o segundo andar. Neste andar, encontramos uma sala de plantão onde permanecem as agentes e no centro, entre as alas par e ímpar, uma mesa cercada por grades formando o que lembra visualmente uma jaula, na qual a agente responsável por aquele plantão permanece. 
Assim que entramos nos pavilhões, podemos ver que uma rotina bastante inquieta e agitada se desenvolve por entre os corredores, escadas e celas. Os cheiros se misturam, entre fumaças de cigarro e maconha, entre perfumes baratos, sabonete, cheiro de café e comida.

Vemos agentes, quase sempre bastante jovens, guardando portões de entrada, circulando com rádios para comunicação e chaves, muitas vezes utilizando as mesmas gírias e expressões compartilhadas pelas mulheres internas. Em verdade, é costumeiro que poucas coisas diferenciem visualmente as mulheres presas e as agentes, tanto na aparência física como em expressões e gestos e na origem pobre, a não ser, naquele momento, pela postura mais austera e contida das agentes e pela utilização de uniformes diferentes. A forma de se dirigirem umas as outras também difere, pois enquanto as agentes com frequência se dirigem às mulheres presas chamando-as pelos seus nomes próprios, as presas indistintamente se dirigem às agentes (e a quase todas as outras pessoas que trabalham na penitenciária, ou que vêm de fora) como "senhora" (ou "senhor", no caso dos raros agentes do sexo masculino). O embate no contato umas com as outras, entre as representantes dos dois papéis exercidos, também é visível. A hostilidade ou a tolerância - jamais a convivência afetiva, no máximo pacífica e respeitosa - independe do papel em que as mulheres se encontrem, agentes ou presas.

Há também muitas mulheres presas transitando de um lado para o outro - ainda que precisando parar para que as agentes abram o portão que divide o espaço compartilhado do corredor das celas - conversando, indo para as escolas com livros nas mãos, vestindo roupas de trabalho com uniformes de manutenção, toucas e aventais, fumando; algumas passam com bastante pressa e expressão grave, evidenciando estarem enfrentando ou lidando com alguma forma de problema e conflito. Em dias específicos da semana, podemos ouvir cantos de louvor, individuais ou grupais, ecoando e causando um sentimento que fica entre a emoção e o desespero. Vez ou outra, vemos algumas mulheres carregando sacolas quando o "jumbo" chega e 
eventualmente outros materiais frutos de trabalhos artesanais - que aprenderam a confeccionar antes da prisão ou dentro dela -, como desenhos e pinturas, cestos, bolsas de crochê e colares.

São mulheres de diversas idades, religiões, etnias, orientações sexuais, cores e cortes de cabelo, nacionalidades, estilos, mas podíamos perceber que uma enorme parcela das internas compunha as camadas mais pobres da sociedade. A maioria delas é parda e bastante jovem, raramente encontramos mulheres acima dos 50 ou 60 anos. Circulam mulheres com sotaques diferentes, provenientes de regiões brasileiras diversas e às vezes com línguas diferentes, denotando outras nacionalidades. Há mulheres bastante vaidosas com penteados de cabelo elaborados, brincos; as roupas costumam ser modificadas com detalhes de modo a diferenciá-las (e evidenciar tanto a singularidade do indivíduo quanto muitas vezes sua melhor condição financeira), mas há também mulheres bastante descuidadas, abatidas. É difícil supor a idade da maioria delas, na medida em que parecem muito mais velhas do que na realidade são. A dentição chama a atenção, quase todas têm a arcada dentária bastante prejudicada, com dentes escurecidos ou ausentes, pelas más condições de cuidado desde antes mas principalmente após o cárcere, pelo alto consumo de tabaco e, em alguns casos, também de outros tipos de drogas.

Encontramos também mulheres que adotam vestimentas, cortes de cabelo e nomes masculinos de forma que, a um primeiro olhar, acreditaríamos estarmos olhando realmente para um homem, exceto pelo fato de usarem também a camiseta branca e a calça amarela ou bege. Estas mulheres assumem algumas características culturalmente atribuídas aos homens como o cavalheirismo - carregando as compras de suas companheiras ou aceitando tomar banho frio para que as namoradas ou companheiras de cela possam tomar o banho com a parte da água que vem quente - e o cortejamento, dirigindo olhares e fazendo galanteios mais ou menos acintosos às outras mulheres que passam.

O barulho é bastante opressivo, pois a altura das galerias faz ecoar o ruído das conversas massivas e, vez ou outra, gritos isolados ecoam mais alto que os outros sons. Há um 
modo particular de gritar - sempre no mesmo tom - os avisos dentro dos espaços onde ficam as celas, compartilhado entre todas as mulheres presas. Estes gritos ao ecoar nos dão uma intensa sensação de desconforto, talvez de solidão, da possibilidade de perder-se ali no meio de tantas mulheres, ficar ali esquecida entre os tantos "quartos", da possibilidade de haver ou não alguém ouvindo aquela que grita o recado, da incerteza da destinatária quanto a ouvir os recados a ela enviados em algum momento. Há ainda o barulho dos enormes carrinhos de metal ou plástico utilizados para transportar objetos e suprimentos em grande quantidade, devido ao grande número de mulheres internas.

O contato com as mulheres que já começa a acontecer no trajeto do corredor se intensifica no pavilhão, pois raramente alguém que não seja funcionário da instituição ou mulheres presas transitam naquele espaço, e isto fica mais evidente por conta da cor dos uniformes, as camisetas roxas. Os olhares se voltam para as pessoas estranhas que adentram espaço íntimo, e as reações são diversas, desde olhares e comentários hostis - normalmente quando acreditam que se trata de um outro uniforme de agentes penitenciários - a gestos de indiferença, mais raramente observados, passando pela curiosidade e até as reações mais afetivas e receptivas. No entanto, há algo que acontece de modo intenso e recorrente quando nos encontramos com as mulheres presas. Assim que adentramos o espaço somos abordadas por diversas mulheres com pedidos de todas as ordens, desde recursos materiais até informações sobre processos, perguntas sobre saúde e pedidos de contato com suas famílias por telefone para comunicar algo ou obter notícias sobre seus parentes. Observamos a escassez de recursos materiais para aquelas que não recebem um bom “jumbo", a falta de informações e acesso à justiça para as mulheres que não podem pagar por um bom advogado, o contato restrito com suas famílias e amigos por quem frequentemente são abandonadas ao serem presas ou que simplesmente não contam com recursos financeiros para virem visitá-las de outras cidades, estados ou mesmo bairros mais distantes. Ao darem-se conta de que somos pessoas que vêm de fora da prisão, mas não somos "polícia" - modo como 
chamam a todos os funcionários da penitenciária -, representamos uma grande chance de realizar contatos com o exterior ou pessoas para quem se pode diretamente pedir coisas.

Estes pedidos eram mais do que justificáveis, mas numerosos demais para serem todos plenamente atendidos pela equipe de trabalho com que contávamos, ainda que existisse a vontade de assim proceder. Em sua pesquisa com mulheres internas da Colônia Feminina do manicômio judiciário de Franco da Rocha, a psicóloga Margarida Mamede (2006) observou algo semelhante. Em suas palavras Margarida nos diz que:

\footnotetext{
(...) urgente é a necessidade infinita de pedir, pedir e pedir. (...) Poderíamos fazer uma analogia com uma canção de uma nota apenas, traduzida no verbo pedir. (...) Esses insistentes pedidos inevitavelmente deixam-me angustiada, colocando-me diante de um desafio e de uma tensão: elas deflagram e escancaram, a despeito de eventuais interpretações psicológicas, o tanto e o quanto essas pessoas estão despossuídas das mínimas condições de vida. (...) Se não frear esses pedidos vindos delas e se não colocar limites (inclusive para mim mesma), corro o risco de me perder no âmago dessas aflições, sucumbindo à tentativa de oferecer o que pode estar ao meu alcance e responsabilidade. (p. 49)
}

Havia diante destes pedidos grandes sentimentos de pesar, revolta e impotência diante de mulheres cujas histórias anteriores à prisão já traziam tanta negligência, violência e carência e que novamente se viam em um ambiente tão adverso, reforçador dessas experiências anteriores, ainda que a prisão venha por consequência da escolha de ações criminosas por grande parte destas mulheres como reação a esse histórico.

Observávamos que, à parte da realidade e concretude de suas necessidades e faltas, muitos desses pedidos se repetiam também independentemente da resposta a eles obtida e de sua natureza, como se em alguns casos fossem um eco, um pedir "sem fim", e pedir o que quer que seja. Certa vez uma das mulheres presas me procurou pedindo que eu lhe cedesse algumas folhas de papel sulfite que eu trouxera para as atividades do grupo, pois trabalhava com artesanato e este material estava lhe fazendo falta. No entanto, realizou este pedido na frente de muitas outras mulheres que, logo ao ouvirem este pedido, se aproximaram curiosas para ouvir 
a resposta, prontas para exigirem o mesmo privilégio - "se ela ganhou, eu também quero!" -, mesmo que não precisassem do papel em especial. Não haveria a possibilidade de distribuir folhas sulfite a todas as mulheres, de modo que me vi obrigada a negar justificando com esse motivo a elas. Algum tempo depois, na mesma manhã, esta mesma mulher me procurou pedindo que eu lhe cedesse um pouco de cola branca também para artesanato, mas naquele momento eu não carregava comigo este material, o que levou a uma nova resposta negativa. Algumas horas depois, esta moça me procurou novamente com um pedaço de caixa de papelão nas mãos no qual havia escrito um nome e um telefone, me solicitando que entrasse em contato com sua família para comunicar que ela em breve seria libertada. Respondi a ela que ligaria, assentindo então com este terceiro pedido. A confirmação de que uma das demandas havia sido atendida foi recebida com intensa alegria naquele momento, ainda que esta moça não tenha me procurado depois para saber sobre o resultado de minha tentativa de contato com sua família. Eu mesma a procurei e a comuniquei, o que ela agradeceu prontamente, e em seguida me perguntou se naquele dia poderia lhe ceder um pouco de fita crepe utilizada na atividade em grupo que acabava de terminar.

As mulheres reagiam de formas diversas à nossa aproximação. Como as oficinas que realizávamos eram divulgadas abertamente a todas as mulheres presas e eram também optativas, já havia a predisposição por parte das participantes a oferecerem alguma abertura ao contato, seja por curiosidade, seja por interesses diversos, desde interesses em obter vantagens e benefícios - a possibilidade de haver remição pela participação ou de receberem bens materiais como materiais escolares e coisas do tipo - até interesse em preencher o tempo ocioso e solitário. Inicialmente, parecia haver dificuldade em atribuir-nos um lugar, um papel, encontrar uma forma de se relacionarem conosco, já que não éramos 'presas' nem 'senhoras' (agentes). Além disso, não nos comunicávamos com tons de voz e posturas corporais que pudessem ser vistas nem como intimidativos nem como subalternos, formas comuns de contato interpessoal dentro 
da prisão. Isto inicialmente causava desconfiança e medo de que pudéssemos na verdade estar agindo em aliança com a direção da instituição - ou na gíria que utilizam, que estivéssemos 'correndo com a polícia'. Com o convívio entre a equipe e as mulheres presas e a circulação de informações sobre o projeto na unidade prisional - sem nenhum indício de que estivéssemos fazendo um jogo duplo entre presas e direção - essas ansiedades e medos iam arrefecendo. O surpreendente em todo este processo é que, apesar de todos os medos justificáveis e do contato em um ambiente hostil, encontramos raramente mulheres sisudas, bravas, assustadoras. Ao contrário, a recepção em um curto espaço de tempo é bastante afetiva, e muitas expectativas positivas são depositadas nos grupos e no relacionamento pessoal desenvolvido entre as detentas e as integrantes da equipe. Havia de minha parte bastante apreensão de que as atividades não fossem bem sucedidas, de que o grupo não aceitasse realizar atividades lúdicas, e de que o relacionamento pessoal entre mim e as mulheres presas fosse truncado ou turbulento, mas o que encontrei foi o oposto disto. Laços foram construídos, a partir dos quais inclusive o contato através das cartas pôde se estabelecer. Estes contatos são muito significativos em especial dentro deste contexto, em que as mulheres relatam um grande distanciamento nos relacionamentos interpessoais entre elas, nos falam sobre fortes sentimentos de medo, solidão, isolamento e desconfiança e descrevem o perigo existente em expressar opiniões no contexto prisional. Estes laços traziam para mim sentimentos contraditórios, pois ao mesmo tempo em que convivia com mulheres que se mostravam, em sua maioria, bastante afetuosas no relacionamento comigo, sabia muitas vezes também sobre seu histórico, nos quais haviam cometido atos de violência inimagináveis e dificilmente conciliáveis sem grande esforço com as outras impressões que eu havia tido.

Os corredores radiais dos pavilhões eram os locais utilizados com frequência para atendimentos de vários tipos às mulheres. Tratam-se de longos corredores com vastas janelas cujos vidros estão quebrados e de onde se pode ver abaixo os pátios citados anteriormente e por onde entra a luz do sol, diferentemente dos outros lugares dentro do pavilhão propriamente dito, 
reunindo muitas mulheres que permanecem nas janelas fumando ou olhando para fora. Vez ou outra encontramos agentes que também permanecem próximas das janelas olhando para fora do prédio. Este espaço quase sempre se encontra bastante sujo, empoeirado, com pombas e dejetos que estas deixam. Os trabalhos em grupo nos quais atuei como oficineira se realizavam lá.

Há ainda mais dois andares acima com corredores de celas. No segundo andar ficam as salas de plantão e as radiais, no terceiro e no quarto andares ficam salas utilizadas e nomeadas como “jurídico", ou seja, um espaço onde as próprias mulheres presas dão orientação às outras sobre os processos e leis, e os "postos culturais", onde se reúnem e atuam mulheres que se responsabilizam em prepararem os eventos que possam ocorrer na prisão, tais como festas em datas comemorativas, grupos de teatro, pintura e desenho, competições esportivas, entre outros. Essas atividades são raras e a maioria das mulheres internas desconhecem as que são responsáveis pelos postos culturais. Ambas as funções - jurídico e posto cultural - são exercidas como uma forma de trabalho e as mulheres recebem um salário referente a esta função.

Outra atividade realizada pelas mulheres, trabalho pelo qual recebem um salário, é a que chamam de "faxina". Atuar como faxina designa uma série de atribuições que vão desde a limpeza propriamente dita do pavilhão e dos espaços de convivência, até outra função bastante importante na comunicação dentro do pavilhão: as faxinas fazem a comunicação entre os agentes e outros profissionais que não podem entrar nos corredores onde ficam as celas e as presas. Isto ocorre por medida tanto de preservação da privacidade das presas como de proteção da integridade e vida das agentes penitenciárias. Deste modo, quando é necessário comunicar algo às mulheres do pavilhão, lado par ou lado ímpar, é preciso comunicar às agentes que irão chamar a faxina gritando por este nome para dentro da galeria e comunicar a esta o aviso. É a faxina que irá gritar para as outras mulheres o recado ou comunicar individualmente a destinatária da mensagem, dependendo do tipo de recado a ser dado. As faxinas costumam ter ainda outra função velada, pois podem transitar entre os lados par e ímpar de seu pavilhão e com isso 
têm acesso maior a informações dentro da penitenciária. Esta não é obviamente oficial, e sim uma apropriação da função por parte de facção criminosa organizada mais atuante: as faxinas costumam atuar como olheiras e delatoras, representam compulsoriamente os olhos das representantes da facção que não podem estar em todos os lugares ao mesmo tempo. Representam ainda aquelas que atuarão na linha de frente imobilizando agentes, caso uma manifestação se torne rebelião e tome proporções desmedidas. Deste modo, apesar de a maior parte das mulheres presas buscarem trabalho como forma de receber alguma renda e remição de pena (redução do período de detenção em função dos dias trabalhados), esta função costuma ser evitada principalmente por aquelas que não desejam se envolver com a facção. Nem todas as faxinas atuam dessa forma, mas a pressão que sofrem neste sentido é bastante grande, tornando quase impossível desvincular a função oficial da 'extra-oficial'.

Há ainda outros locais e possibilidades de trabalho legalizadas dentro da penitenciária, como a biblioteca, a manutenção, a área administrativa. Normalmente chegam a este último cargo mulheres que de alguma forma conquistaram a confiança dos funcionários desta área. Há também vagas para a 'boia' - que inclui como tarefas desde o trabalho na cozinha até a distribuição das refeições nas celas dos pavilhões - e para as firmas associadas à unidade prisional, as quais são as mais almejadas devido à remuneração por produção e à remição de pena por tempo trabalhado que proporcionam. Por fim, é possível ainda laborar nas escolas, nas quais as próprias detentas atuam como professoras, atribuição esta nomeada como 'monitoria'. Esta deveria contar com supervisão e orientação de um professor designado pela Fundação de Amparo ao Preso Prof. Dr. Manoel Pedro Pimentel (FUNAP), mas segundo as monitoras isso raramente acontecia. A maior parte desses trabalhos oferecia remuneração bastante baixa e poucas condições de realização da atividade de modo seguro ou saudável, ou seja, não eram utilizados os uniformes e instrumentos ideais tais como botas de borracha, luvas e máscaras, expondo as trabalhadoras a situações de risco de ferimentos e doenças. As atividades também não possibili- 
tavam o aprendizado de um ofício que pudesse ser praticado quando estas mulheres deixassem a penitenciária. Ainda assim, há grande expectativa pela conquista de uma vaga, pois para a população geral da penitenciária o número oferecido é muito pequeno.

Existem outras formas de trabalho dentro da penitenciária, mas que não são autorizadas pela instituição, tais como o comércio, por exemplo. Como não há dinheiro dentro da penitenciária, esses trabalhos são realizados em troca de outros bens de consumo ou serviços, como por exemplo, maços de cigarro - a principal moeda de troca dentro da prisão -, ou outros artigos que possam ter vindo no "jumbo", trocas de serviços como corte e tintura de cabelo, maquiagem, limpeza de celas, aulas de artesanato, venda de cosméticos e até mesmo tráfico de drogas, entre outros. Sobre isso me falou um pouco a detenta Simone :

\footnotetext{
Quando vim para cá, vim junto com as meninas da $97^{\mathrm{a}} \mathrm{DP}$, eu já tinha amizade com elas, uma delas já tinha sido presa antes e nos preparou. Ela me disse "fique muda, ouça menos ainda". As palavras pesam muito aqui. Como eu não era do crime e nem tinha um bom “jumbo”, precisei arrumar tudo por aqui, absorvente, coisas. Então comecei a limpar a cela das pessoas, perguntar se tinha alguém que precisava que limpasse a cela. No meu primeiro "jumbo", veio muita coisa, então pude começar a trocar por cigarro. Saí gritando pela galeria quem queria comprar as coisas que vieram no "jumbo".
}

As escolas da penitenciária também oferecem um pequeno número de vagas, mas sua procura também é muito menor que a procura por trabalho. Lá encontramos poucas analfabetas ou com baixíssima escolaridade nesta penitenciária, ainda que também baixos índices de mulheres com ensino médio completo e superior. As mulheres alegam diversos motivos pelos quais poucas presas procuram e se mantêm na escola. Um dos fatores é a falta de organização, pois muitas vezes as aulas são suspensas por falta da monitora ou pelo pequeno número de alunas presentes na sala de aula. As alunas também costumam abandonar as aulas quando estas coincidem com o horário de trabalho, caso consigam uma vaga. Consideram também muitas vezes que o conteúdo já está ultrapassado para a sua formação e desanimam. Outro fator relevante é que muitas mulheres presas não aceitam ter aulas com monitoras que também sejam 
internas, pois julgam que se elas são presas também, não terão nada para ensinar às outras. Por diversos motivos, desde que as mulheres chegam ao pavilhão na prisão são desencorajadas por outras internas mais antigas a frequentarem a escola, como se esta fosse um desperdício de tempo. Há também mulheres que alegam não suportarem dedicar tempo a atividades que possam trazer pausas no cotidiano, reflexões sobre sua condição atual e sua vida ou preencher o tempo de modo demorado, tais como os conteúdos da escola, e procuram se dedicar a outras atividades que, como dizem, "façam o tempo passar mais rápido". Parece bastante difícil para as mulheres realizar atividades que exijam atenção, foco e concentração, já que procuram com afinco preencher seu tempo com atividades que as levem a não sentir a passagem do tempo e as dores emocionais relacionadas ao cárcere.

No entanto, há mulheres que perseveram e mantêm sua frequência nas aulas da escola, conseguindo concluir suas formações. Estas acreditam que estudar é uma forma não só de retomar um objetivo e um propósito de vida, mas também de preencher o tempo de forma construtiva, podendo ainda mostrar aos seus familiares que, apesar de estarem presas, estão aproveitando esse tempo para se desenvolverem e construírem um futuro melhor para si e para os outros. Existe fortemente o desejo de dar o exemplo como mãe aos filhos que deixaram quando foram presas, e a escola muitas vezes representa uma saída neste sentido.

Os representantes da direção e os responsáveis pela área da educação dentro da penitenciária tendem a interpretar esses dados sobre a baixa procura pela escola como desinteresse por parte das presas, tanto em progredir nos estudos, como em investir em qualquer atividade em que o retorno seja o desenvolvimento pessoal sem que exista possibilidade de ganho em dinheiro ou bens materiais. Por outro ângulo, todavia, é possível supor que a escola em certos casos parece mais estar respondendo à obrigatoriedade institucional de oferecer a educação como um direito formal dentro do cárcere - ou seja, que apenas 'exista' uma escola da forma que 
for - do que realmente representando um esforço em oferecer ensino e educação de qualidade levando em conta seu público alvo e suas especificidades e buscando a melhoria de sua condição.

Ainda que a maioria das mulheres presas nesta unidade não trabalhe nem estude, são mantidos horários-padrão fixos a todas as mulheres desde o café da manhã, almoço e jantar até mais tarde, no horário do recolhimento para as celas, em que todas as luzes se apagam. Chamou-me a atenção a ausência de relógios dentro da prisão e o constante questionamento das mulheres com relação ao horário. Em conversas descobri que não só não há relógios nas paredes como o uso destes nos pulsos é proibido pela instituição com a justificativa de que horários para paralisações ou rebeliões poderiam ser combinados com a ajuda dos relógios. No entanto, a ausência de relógios nunca foi impeditivo para estes acontecimentos, tornando questionável a justificativa na forma como ela se apresenta. Por outro lado, a ausência destes é um dado relevante também na compreensão dos problemáticos atrasos nos horários de aula nas escolas já citados acima. Outra regra cuja justificativa também mostra-se difícil de compreender do modo como nos é apresentada refere-se à proibição da posse e uso de espelhos. O motivo seria a possibilidade de construção de armas com pedaços de espelhos. No entanto, são permitidas lâminas de barbear utilizadas pelas mulheres para depilação, as quais também poderiam facilmente ser utilizadas como armas. Podemos pensar que a proibição de relógios e espelhos tenha prioritariamente a função de desorganizar subjetivamente as mulheres presas, na medida em que interferem em suas noções de tempo e de individualidade, ressaltando-se aqui mais uma característica subjetivamente opressiva da instituição prisional velada sob justificativas acerca da segurança.

No dia a dia da prisão, convivemos também com o alto consumo de tabaco e de drogas pesadas. Muitas mulheres apresentam históricos de envolvimento com drogas desde antes da prisão e algumas continuam como consumidoras mesmo dentro da cadeia. $\mathrm{O}$ uso de drogas é um assunto tabu dentro do sistema penitenciário na medida em que envolve grande parte das mulheres presas, trazendo problemas graves de saúde e mortes, mas não pode ser abordado dire- 
tamente como um problema sem que se admita que as drogas estão presentes no cotidiano e que portanto conseguiram passar pela vigilância da prisão. O tabaco constitui também um grande problema de saúde dentro do cárcere, sendo bastante difícil conhecer mulheres que não fumem, mas assim como as drogas, dificilmente será abordado como um problema e tratado abertamente dentro da cadeia, já que os cigarros são utilizados como principal e importantíssima moeda de troca entre as mulheres, possibilitando um comércio que é proibido pela instituição.

As deficiências no que tange à saúde física e mental dentro da penitenciária também são evidentes no cotidiano prisional. Vemos mulheres andando pelos espaços com dores, circulam notícias de mulheres acamadas e gravemente doentes com consultas marcadas para meses adiante, há numerosas crises epiléticas, algumas das quais presenciamos e que precisaram ser contidas e socorridas por outras mulheres presas. $\mathrm{O}$ atendimento médico costuma ser prestado apenas em casos bastante graves, enquanto os outros tendem a ser adiados, pois precisam de transporte e escolta para que possa ser realizado em um hospital próximo, e portanto externo, ao complexo prisional. Há o hospital penitenciário, mas as vagas não são suficientes diante da demanda existente, de modo que mesmo as gestantes acabam indo para o hospital bem próximas de darem à luz ou quando já tiveram seu bebê dentro da penitenciária.

É bastante elevado o número de mulheres em tratamento com medicações psiquiátricas. De casos de psicose, depressão e epilepsia até crises de ansiedade e insônia, todos são tratados com medicações psiquiátricas após consultas com um médico. Estas consultas costumam acontecer entre períodos muito extensos de modo que o acompanhamento está muito aquém do ideal. Ocorrem situações em que a medicação prescrita não é a adequada para um determinado caso tanto em relação a sua função quanto em quantidade, podendo trazer outros sintomas desagradáveis: inchaços, desatenção, apatia. Algumas se automedicam ou param o tratamento por conta própria. Assim, medicações começam também a circular como moeda de troca e a serem comercializadas entre as mulheres. 
Alguns casos de sofrimento psíquico e emocional apresentam um histórico anterior à prisão e agravados pelo contexto em que vivem, mas que são tratados por sintomas surgidos e apresentados dentro e por conta do contexto prisional. Além dos espaços restritos apresentados para elaboração das experiências e sofrimentos - como, por exemplo, a dificuldade em confiar e encontrar alguma companheira de penitenciária com quem possa conversar -, os atendimentos disponíveis com psicólogas da instituição, além de raros, nem sempre podem representar um vínculo de confiança. Isto porque as questões trabalhadas nos encontros são registradas pelas profissionais na ficha da interna, podendo prejudicá-la futuramente em seu processo.

Há ainda outras formas de elaboração da experiência da prisão observáveis no cotidiano desta penitenciária. A arte é uma das mais importantes e se manifesta de diversas formas. Coletivamente, existem grupos musicais de pagode e rap, formados por detentas, que ficam conhecidos por todos os pavilhões com suas letras em geral sobre o cotidiano da cadeia, experiências de vida, saudades da família e amor. O teatro também é uma forma de expressão bastante buscada pela mulheres, que muitas vezes ensaiam peças para apresentarem em datas comemorativas. Há ainda formas de expressão mais intimistas como as mulheres que escrevem poemas e textos e as que pintam ou desenham.

Outra expressão importante das tentativas de atribuição de sentido ao viver no cárcere é a religião. A penitenciária costuma receber visitas de religiosos com credos diversos. Há visitas principalmente de grupos e representantes católicos, evangélicos e espíritas, e observamos o crescimento intenso dos grupos de oração e cantos de louvor evangélicos que podem ser vistos dentro do pavilhão e nos pátios, chamando bastante a atenção das pessoas que convivem diariamente dentro da penitenciária.

Fazem parte também do cotidiano dentro dos pavilhões as chegadas e partidas das presas. A chegada das novas detentas é um momento aflitivo para quem assiste, pois sabe-se que chegam com poucos pertences pessoais sem saberem se serão recebidas e em que celas e que ali 
permanecerão por um tempo razoável sob condições bastante complicadas. As 'Ros', grupos de mulheres advindas do alojamento da 'inclusão', são levadas aos pavilhões carregando um colchão de espuma fino, uma sacola com algumas poucas roupas, um cobertor, um sabonete e uma escova de dente. O ruído que já é bastante alto fica ainda mais forte. Ficam por bastante tempo de pé aguardando nos corredores radiais enquanto as faxinas gritam para dentro dos corredores onde ficam as celas que as 'Ros' chegaram. Isto acontece porque são as mulheres que já estão alojadas e ainda têm vagas em suas celas que irão escolher a 'Ro' que irá ocupar esta vaga. Algumas das recém-chegadas são reincidentes ou já têm conhecidas dentro da penitenciária, irmãs, amigas, entre outras, e pode-se ouvir gritos por nomes e comemorações pela chegada de algumas mulheres em especial. A maior parte delas, no entanto, permanece na expectativa de uma definição sobre o lugar em que ficarão alojadas, o que gera bastante ansiedade, principalmente entre as que são primárias e não têm experiência na prisão. Dentro de algum tempo, as 'Ros’ já se encontram instaladas sem qualquer participação ou interferência por parte da instituição neste processo de assimilação das recém-chegadas.

As saídas das mulheres presas que recebem seu alvará e retomam seu direito à liberdade costumam ser momentos bastante emocionantes. Isto é tão mais intenso, pois há casos em que, tendo a detenta permanecido por quase todo seu período de prisão sem receber informações sobre o seu processo, esta notícia vem como uma surpresa, e sua saída precisa ocorrer no mesmo dia de sua comunicação. São eventos mais solitários do que a chegada, pois recebem essa notícia individualmente. Muitas vezes estamos nos corredores e espaços dentro do pavilhão quando ouvimos uma gritaria de alívio e felicidade, misturada com choro e agradecimentos a Deus. As outras mulheres a parabenizam e comemoram com ela neste momento, e a mulher precisa começar a recolher suas coisas e se despedir das colegas que muitas vezes a encarregam de levar recados a seus parentes que estão do lado de fora. As mulheres evitam deixar objetos pessoais, em especial fotografias delas, pois é generalizada a crença de que se o fizerem, retornarão à prisão. A mulher 
precisa devolver seu colchão, uniforme e cobertor para a penitenciária para que outras detentas os utilizem no futuro. Os alvarás de soltura costumam chegar no final da tarde, período no qual estas mulheres são libertadas com uma sacola contendo seus pertences pessoais e uma carta que a habilita a tomar quantas conduções forem necessárias gratuitamente para retornar ao seu lar ou ao local onde irá se hospedar. Poucas orientações quanto a benefícios e possibilidades de reinserção e amparo social são oferecidas antes que essas mulheres deixem a penitenciária feminina.

\subsection{Uma figura esquecida no cenário prisional: as agentes penitenciárias}

No cenário prisional, a figura do agente penitenciário tem recebido pouca atenção seja nos modestos estudos existentes sobre seu ponto de vista, suas experiências e percepções no exercício de sua função, seja nas atividades e trabalhos desenvolvidos dentro das unidades prisionais, tendo os estudiosos em geral se dedicado mais ao estudo da experiência dos presidiários e dos criminosos. Ainda que ao longo do trabalho que desenvolvi nesta penitenciária tenha havido maior contato com as mulheres presas e pouco contato direto com os funcionários e as agentes penitenciárias, este trabalho se dedicará também a considerar e refletir mesmo que ligeiramente acerca da condição destas últimas, evitando incorrer em reduções pragmáticas limitantes para a aproximação à questão em estudo. Não será possível neste trabalho abordar a questão das agentes penitenciárias plenamente, mas se buscará apresentar as experiências, observações e reflexões realizadas para que estas possam levantar e fomentar problemáticas a serem estudadas futuramente.

Conforme já descrito anteriormente, durante o período em que atuei na penitenciária, meu contato com as agentes penitenciárias ocorreu de duas formas: no dia a dia, durante 
a realização das oficinas com as mulheres presas, e durante a realização de atividades com dois grupos de agentes penitenciárias enquanto estas ainda concluíam o curso de formação (a maioria delas já em atividade mesmo antes de concluir a formação).

No cotidiano, era possível observar diferenças no modo de realizar o trabalho e de compreender a prisão e a função que exerciam de acordo com o quão longo era o período que determinado profissional vinha exercendo a atividade. As agentes que trabalhavam há mais tempo na função muitas vezes expressavam certo sarcasmo diante da postura das agentes recém-chegadas em demonstrar compaixão por algumas presas e sua condição, e frequentemente buscavam alertar as novas colegas quanto a manter este olhar mais sensível, pois as impediria de ver malícia nas ações das presas. Esta forma sarcástica de reagir também se manifestava algumas vezes no contato com os grupos que vinham realizar algum tipo de trabalho com as mulheres presas, como se houvesse por parte destas pessoas uma ingenuidade risível e ignorante a respeito da realidade da prisão e de quem seriam aquelas mulheres. Lembro que havia um agente penitenciário que, diante de cada uma das visitas que realizávamos, nos recebia sempre com um sorriso provocativo e com a expressão "Bom dia, meninas! Bem-vindas ao Paraíso!", fazendo um gesto cortês com os braços indicando o caminho. Ainda que a repetição invariável desta frase me causasse alguma irritação, não podia deixar de pensar que aquele era o 'paraíso' no qual aquele agente penitenciário passava grande parte das horas de seus dias, há tantos anos, e no quanto de seu próprio sofrimento estaria expresso naquela provocação. A relação das agentes mais antigas com as mulheres presas também era diversa da estabelecida pelas agentes novatas, havendo reduzida ou nenhuma tolerância e sensibilidade diante das demandas trazidas, desde solicitações de trânsito dentro do pavilhão até pedidos de socorro para problemas de saúde. Estes agentes não apenas estavam há mais tempo expostos ao contexto prisional e suas contradições e violências no contato direto com as mulheres presas: ainda que não seja uma regra, era sabido que grande parte dos agentes que ali estavam há muito tempo haviam passa- 
do por situações de violência mais intensas no exercício de sua função, como por exemplo ter sofrido algum tipo de ameaça e intimidação ou ter estado presente durante alguma paralisação ou rebelião. No entanto, pouco se pode dizer acerca de suas impressões além da observação no dia a dia e de alguns comentários ou breves relatos de experiências que faziam nos breves momentos de contato, pois não foi possível realizar nenhuma atividade especificamente com estes profissionais ou ouvi-los separadamente. O exercício da função exigia atenção constante e de todos os funcionários presentes, não sendo possível retirá-los mesmo que momentaneamente e alternadamente para propor grupos ou trabalhos voltados para agentes. Deste modo, o único acesso possível aos agentes se deu com as que eram novas no cargo dentro da Escola de Agentes Penitenciários, que se encontravam ainda em vias de concluir o curso de formação.

Quase todas as agentes que estavam na escola - com quem tivemos contato - já haviam iniciado o trabalho mesmo antes da conclusão das aulas. Não havia homens nas duas turmas com que conversamos, e a maior parte delas era bastante jovem. Quando perguntadas sobre sua cidade natal, quase nenhuma delas nasceu ou vivia no momento na cidade de São Paulo, advindo de cidades diferentes de todo o estado de São Paulo. Isto se dava porque o concurso para esses cargos era realizado para o estado todo, e a distribuição dos aprovados se dava pelo chamamento dos candidatos com as maiores notas para os locais onde havia maior demanda. Não havia a possibilidade de escolher a cidade de trabalho, de modo que as agentes reclamavam terem sido prejudicadas ao saírem-se bem no concurso, já que isto resultou em precisar ir para longe de casa, vindo para a capital.

Quando perguntadas sobre o motivo para escolherem prestar este concurso, estas foram as respostas mais recorrentes: a estabilidade no emprego proporcionada pelo fato de trabalhar como um profissional concursado, a renda mensal, o status "honroso" do cargo público e a concepção de que se trata de um trabalho em que se faz algo correto. Sabendo que a maioria delas já havia iniciado o trabalho, perguntamos quais as diferenças entre estas expectativas e o 
que vinham encontrando na realidade diária. As agentes relataram que o fato de terem vindo para a capital trouxe muitas mudanças, pois não verificaram aqui o mesmo status atribuído ao cargo público que existia nas suas cidades de origem. Além disso, a renda que em outra cidade seria o suficiente para viver com conforto, em São Paulo não representava o mesmo devido ao custo de vida mais alto. A mudança também implicou na adaptação em uma cidade diferente e no afastamento de amigos e familiares em troca de uma rotina mais solitária, na medida em que vinham sozinhas para São Paulo, vivenciando experiências de desenraizamento e solidão. No dia a dia, verificavam que nem sempre ser agente penitenciário significava fazer algo correto, tanto no fato de verificarem que outros agentes também participavam de atividades ilícitas como também pelas implicações do próprio papel a exercer, que exigia uma posição que frequentemente não era natural a estas mulheres antes. O papel atribuído à função implicava numa postura antes desconhecida de distanciamento e subjugação de pessoas com quem facilmente se identificariam em outras circunstâncias: mulheres jovens com filhos, namorados, sonhos, assim como elas mesmas, e que frequentemente usavam expressões de linguagem e gestos e tinham referências culturais (música, arte, dança) semelhantes aos delas. Os dias de visita pareciam ser os mais difíceis pela tristeza em verem filhos se despedindo de suas mães, mulheres se despedindo de seus amigos queridos e parentes, a distância e a saudade que também pareciam estar experienciando. No dia a dia prisional, essas identificações eram impedidas pelo fato de exercerem papéis opostos: de um lado as mulheres a serem recuperadas, controladas e submetidas à fiscalização e vigilância por cometerem delitos, e do outro aquelas que atuam como agentes de recuperação, controlando, fiscalizando e vigiando.

Entretanto, havia também hostilidade com relação aos trabalhos voltados para as mulheres presas. Ainda que haja pontos em comum entre as mulheres presas e as agentes como mulheres que muitas vezes advêm de um contexto social de vida semelhante - havia também um sentimento de injustiça. Alegavam que diante das dificuldades, escolheram lidar 
ou sobreviver a ele através da honestidade, evitando envolverem-se com crimes e ganhos fáceis e que, apesar disso, eram as presas quem recebiam cursos de inglês, academia, grupos de discussão. Sentiam-se pouco olhadas, cuidadas e reconhecidas em sua atividade e seu esforço ao não sucumbirem à criminalidade e achavam injusto portanto que pessoas que haviam escolhido o outro caminho recebessem mais atenção e tivessem mais oportunidades.

Podemos pensar então que não somente a própria função a ser exercida por si só já imponha uma série de contradições, riscos e dificuldades, como também que os conflitos e os sofrimentos inerentes ao exercício deste papel de agente carcerária, neste contexto, acabam ficando invisíveis no contexto prisional em detrimento da atenção dispensada à experiência das mulheres presas. 


\title{
CAPÍtulO 2 \\ Os relacionamentos interpessoais no cárcere
}

\author{
Oi, já estou com muitas saudades, não te vi mais aqui na \\ penitenciária. Eu ainda estou aqui, mas tenho fé que ainda esse ano \\ eu vou embora para honra e glória do senhor Jesus Cristo. (...) \\ Fernanda, eu agradeço a Deus por ter te conhecido, pois eu \\ aprendi muito com vocês, gostei muito dos dias que nos encontramos, \\ e vi até que tem algumas companheiras boas. Continuo de cela, só \\ saio para ir no culto e nos ensaios do grupo de louvor pois sou \\ regente, só pela misericórdia de Deus, e quando não estou estudando \\ a bíblia e no culto ou no ensaio, estou na cela ouvindo os cultos \\ da igreja, fazendo crochê e bordando. Graças a Deus consigo me \\ manter fora das coisas erradas e servir a Deus, pois pretendo sair \\ daqui e voltar a ter a minha vida normal de pessoa honesta, cuidar \\ da minha família e servir a Deus com todo o meu coração. \\ - Trecho de carta de Ana
}

\begin{abstract}
Apesar desse lugar, me encontro maravilhosamente bem, pronta para qualquer momento estar indo embora. E já estou com o semiaberto montado, só falta vir aprovado e o melhor de tudo, ganhei 7 anos e 5 meses da minha cadeia e logo mais estou no mundão pra cuidar do meu filho. Falando nele, ele está bem graças a Deus, e a minha família também, já o meu amor, esse eu não tive mais notícias, também nem quero mais saber, ele saiu e até agora não escreveu nenhuma carta, é sinal que não merece o meu amor. E você? Me conta as novas da rua, vocês vão voltar pra cá? Olha, amiga, mesmo que nós não nos encontramos novamente saiba que levarei comigo tudo que aprendi no grupo e algumas amizades que fiz neste lugar.

- Trecho de carta de Jussara
\end{abstract}

\subsection{Os problemas e as queixas mais comuns}

Assim que adentramos o espaço prisional, logo começamos a identificar uma série de aspectos que o tornam geradores de intenso sofrimento físico e psíquico que se relacionam não somente à restrição da liberdade de ir e vir, mas também às condições de vida destas pessoas durante o período de reclusão assim como as rotinas possíveis a serem estabelecidas neste lugar. Nesta penitenciária em especial, muitas dessas condições não diferem das já cuidadosamente descritas em muitos trabalhos anteriores a este. O estado de deterioração dos prédios, por trata- 
rem-se de construções antigas e raramente alvos de manutenção, o negligenciamento da higiene do local e as consequências disto, a saúde, a superlotação, a péssima alimentação, a violência, entre muitas outras questões que, ao menos através de debates, programas de televisão, filmes e livros, já se tornaram conhecidas do grande público.

Quando os primeiros contatos e visitas começaram a acontecer, talvez tenha sido com esta perspectiva que pude avaliar inicialmente quais eram os problemas mais urgentes naquela unidade, supondo que estes fundamentariam a maior parte das queixas e demandas por mudanças trazidas pelas mulheres presas assim que houvesse espaço para expressá-las. Para minha surpresa, estas questões eventualmente surgiam, mas não eram nem de perto as problemáticas mais recorrentes.

Esse espanto evidencia alguns fatores relevantes nesta experiência que, podemos pensar, são fortemente relacionados à desigualdade social representada no olhar inicial da pesquisadora, advinda da classe média e branca, diante da situação compartilhada ali por muitas mulheres de origem pobre ou miserável e em sua maioria negras ou pardas - ainda que compartilhássemos a condição de mulher e muitas referências culturais.

Chamava-me a atenção as condições sanitárias do local, o fato de aquelas mulheres conviverem diariamente com as baratas que saíam dos bueiros, com a necessidade de articularem estratégias para evitarem a entrada de ratos nas celas, o mau cheiro causado por partes de alimentos que caíam no trânsito dos carrinhos que entregavam a 'boia'. Da mesma maneira, as dificuldades em acessar os cuidados médicos mesmo em casos muito graves também eram preocupantes não só pelo risco de vida para aquelas pessoas doentes individualmente, mas também pela possibilidade de transmissão de doenças contagiosas em larga escala dentro da prisão, como a tuberculose, por exemplo. Portanto espantava-me que estas mulheres raramente se queixassem desses problemas ou manifestassem sentimentos intensos e viscerais acerca deles. Ocorria que, vez ou outra, falassem sobre o assunto, mas mais com preocupação e familiaridade 
com estas condições - como algo muito ruim que faz parte do cotidiano e que deve ser contornado -, do que propriamente indignação e ânsia por mudanças individuais e coletivas.

Ainda que essa atenção e preocupação fossem inteiramente legítimas - tendo-se em perspectiva as condições mínimas para o viver digno de qualquer ser humano -, partiam de alguém que nunca antes precisara experienciar situações tão precárias em sua história de vida, que sempre pudera contar com condições sanitárias adequadas e acesso à saúde por convênio médico, por exemplo. Essa não era a experiência da maioria das mulheres ali presas. Ao contrário, elas, em sua maioria, haviam constantemente convivido com a falta de condições mínimas para viver e precisado recorrer a esforços individuais para lidarem com situações em que se viam deixadas à própria sorte para resolvê-las, sem acesso a direitos que lhes deveriam ser garantidos. Simone Weil, ao nos falar de sua experiência ao tornar-se operária da Renault, narra seu espanto com sua própria reação diante da repetição diária de vivências que abalavam seu sentimento de dignidade e respeito próprio. Notou com muito pesar que, diante de um cotidiano brutal, brotava em si mesma não o sentimento de revolta, mas o da docilidade, sentimento este que confessa sem orgulho nenhum e que tendia a ser silenciado naqueles que o sentiam por tratar-se de algo doloroso por demais até mesmo para ser pensado. Assim ela escreve: "Quando há uma infelicidade profunda, um pudor muito grande detém as queixas. Assim, cada condição infeliz entre os homens cria uma zona de silêncio, dentro do qual os seres humanos ficam encerrados como numa ilha" (WEIL, 1979, p. 139). Deste modo, penso que diante deste tipo de dificuldades, tristemente estas mulheres já haviam aprendido formas para resolvê-las ou contorná-las através de um esforço individual que tirava de perspectiva a negligência estatal e o fato de tratarem-se de problemas de ordem social e, portanto, coletiva. Assim, as dificuldades mais frequentemente citadas eram as que surgiam principalmente em pontos nos quais não podiam resolver os problemas por conta própria e na esfera dos relacionamentos interpessoais e afetivos, tanto com quem está dentro como com quem ficou do lado de fora da prisão enquanto elas cumprem sua pena. 
Dentre as principais queixas que envolvem a impossibilidade de resolução de problemas de forma individual e independente, estão três mais frequentes, a saber: a falta de atividades dentro da cadeia, a dificuldade em obter informações sobre o andamento de seus processos judiciais e a escassez de notícias sobre seus entes queridos - devido às poucas visitas que recebem, esta última também pertence à esfera dos relacionamentos afetivos dentro e fora da prisão.

A rotina permeada por muitos momentos ociosos era compartilhada pela grande maioria das mulheres da penitenciária. Como já vimos anteriormente, havia algumas atividades possíveis, tanto oferecidas pela própria penitenciária - trabalho e escola -, como as criadas e desenvolvidas pelas próprias presas. Portanto, convém olhar mais de perto para buscar compreender melhor esta queixa. Primeiramente, podemos levar em conta um aspecto desse cenário que diz respeito ao número de vagas oferecidas de emprego em proporção ao numero de mulheres internas e desejosas de trabalhar. A quantidade de postos disponíveis para trabalho era muito pequena para o público da penitenciária, implicando realmente que muitas ficassem aguardando em uma longa e demorada lista de espera até que fossem chamadas para finalmente iniciarem o trabalho. Além disto, algumas das vagas eram designadas por superiores a detentas consideradas "de confiança” - como no caso das funções próximas aos cargos administrativos -, enquanto outras, conforme já descrito, tinham sua função associada a postos da facção criminosa hegemônica e ofereciam riscos em uma possível rebelião e portanto eram muitas vezes evitadas por mulheres que não buscavam este envolvimento.

Havia também a escola penitenciária, na qual sobravam vagas devido à baixa procura das internas. Dentre as atividades propostas pela penitenciária, a escola era preterida em função do trabalho por vários motivos. O trabalho, por exemplo, oferecia não somente um salário como também a remição de pena (um dia de pena para cada três dias trabalhados), benefícios estes não oferecidos pela escola. Além deste, há também os motivos para a evasão da escola já descritos no capítulo 1, como o desencorajamento ao estudo por parte das internas mais antigas 
às presas recém-chegadas (colocando o estudo como um investimento de tempo desperdiçado), a rejeição ao fato de outras colegas presas exercerem a função de professoras, o conteúdo defasado ou limitado das lições e o fato de as aulas implicarem um exercício de concentração e percepção da passagem do tempo a que as mulheres buscam constantemente evitar.

Deste modo, restam as atividades que as próprias presidiárias desenvolvem, como artesanato, arrumação e limpeza de celas, cuidados com a estética (sua própria e a das outras colegas quando esta função se torna um serviço), higiene das roupas, pintura, grupos religiosos e o tempo para interagir socialmente com as outras colegas. Essas atividades são escolhidas de acordo com os planos de vida e interesses de cada mulher, mas todas parecem visar à retirada de atenção da percepção da passagem do tempo e da condição em que se encontram. Por exemplo, pode-se sobreviver emocionalmente à experiência da prisão mantendo-se em perspectiva o mundo e a vida que se deixou fora da cadeia, procurando-se rever os erros passados e objetivando não repeti-los, construindo uma vida diferente da que levava anteriormente, por vias honestas. Se esse é o objetivo, essa mulher buscará preencher os momentos ociosos com ocupações associadas à sua recuperação moral como o trabalho ou a religião e com atividades repetitivas que não ofereçam espaços para reflexão sobre a solidão, o tempo restante de pena, os problemas que enfrentará após sua saída, entre outros. Além disso, preencher este tempo, segundo relatam as mulheres, tem a função de evitar contato com colegas que possam desviá-las desse caminho, pessoas que são consideradas más influências pois não só pretendem deixar a vida desonesta como também oferecem possibilidades de privilégios por meios escusos. Para essas mulheres que querem deixar de ser criminosas, o tempo ocioso oferece o duplo risco do sofrimento prolongado na duração de sua pena e o de não conseguir romper com este modo de viver a vida de forma desonesta.

Entretanto, há mulheres que, ao verem seu dia a dia transformado em sua totalidade na experiência do cárcere, parecem mergulhar nele e o vivem como se o mundo fora da prisão houvesse deixado de existir. Em alguns casos, como nos de mulheres que foram condenadas a pe- 
nas muito longas ou que já estão em idade avançada e sem previsão de receberem seu alvará, esse posicionamento é inclusive um dos poucos possíveis. Algumas mulheres não veem ou não desejam outra perspectiva que não a vida através do crime e portanto não entendem sua prisão como um evento único, mas possivelmente um entre outros anteriores ou que ainda se seguirão. Há ainda mulheres com um longo histórico de internações em instituições totais, desde a infância e adolescência até a vida adulta, de quem se pode dizer que o cotidiano da prisão é mais familiar do que qualquer outro cotidiano. Nesses casos, a passagem do tempo da sentença e a reflexão sobre a condição de encarceramento são evitados através da naturalização da experiência da prisão e a abdicação da expectativa pela expiração de sua pena. As atividades buscadas poderão ser desde o engajamento em atividades e postos dentro da facção criminosa, como em atividades culturais que exijam dedicação a longo prazo (como o planejamento e a elaboração de peças teatrais), ou simplesmente passar o tempo conversando com as outras detentas e tomar banhos de sol no pátio. Uma forma possível de compreender esta queixa sobre a falta de atividades talvez seja a de que, além das poucas atividades disponíveis - que mesmo em número reduzido observamos que ainda se apresentam algumas alternativas - haja também o incômodo com a repetição não só das atividades, mas do espaço em si e das pessoas com quem interagir. Certa vez, durante uma conversa com a presa Simone, perguntei a ela do que mais sentia falta do mundo fora da prisão e ela me respondeu: "Eu sinto muita falta de fazer meus corres". Quando perguntei a ela o que queria dizer, ela explicou que quando não se está presa, os problemas surgem, mas existe a possibilidade de encontrar diversas soluções para ele, contatando pessoas, indo a lugares diferentes, ou seja, a liberdade possibilitava a independência e a criatividade para resolver pendências e dificuldades. Assim era não somente na resolução de dilemas, mas também na forma de encontrar diversão em locais diferentes; encontrar conforto no contato com pessoas com quem se escolhe conviver, com quem há prazer em dividir a companhia, poder acionar uma rede de relacionamentos pessoais na família, amigos e vizinhos em quem se confia e onde existe afeto. 
Outra queixa muito frequente entre as mulheres é de que muito poucas são as presas que recebem visitas por parte de seus familiares, parceiros e amigos, permanecendo longos períodos sem notícias sobre seus entes queridos. Na medida em que atualmente muitas mulheres são chefes de família e encarregam-se do seu sustento e pelo atendimento de suas necessidades, quando uma mulher é presa, a estrutura familiar sofre um fortíssimo abalo quando não um total rompimento. Este abalo da estrutura familiar desencadeia sentimentos e reações muito diversos dos observados quando quem é preso é o homem (LOPES, 2004). A estigmatização dessas mulheres não se limita ao fato de terem sido presas; estende-se também a outros papéis femininos esperados, de modo que a mulher criminosa passa a representar também a má esposa, a mulher malévola e a mãe desnaturada. Esse estigma permeia suas relações dentro da instituição, entre elas mesmas, a relação consigo próprias, e também com seus familiares, companheiros, amigos, conhecidos e filhos. Conversando sobre as visitas com uma das presas que estava cumprindo pena a pouco mais de seis meses, esta fez o seguinte relato:

\begin{abstract}
A minha família sempre confiou em mim porque eu nunca escondi nada deles. Eles acreditam no que eu contei, mas a demora em resolver e também por confiarem na polícia, isso pôs a dúvida na cabeça deles. Meus filhos e meu marido acreditam em mim, mas meus irmãos e irmãs já não me escrevem mais com tanta frequência. Meu relacionamento com meu marido mudou. Ele já está cansado de vir na porta da cadeia. Acaba que um culpa o outro. Antes a gente trocava carta, mas agora não nos correspondemos mais, esfriou. Acho que nos culpamos por não encontrar uma explicação lógica, e tentar encontrar um porquê que não existe. A minha situação não existe.
\end{abstract}

É muito comum que as mulheres sejam abandonadas por seus parceiros quando são presas, o que raramente ocorre quando no casal quem vai preso é o homem. No entanto, quando essas mulheres recebem visitas de companheiros ou companheiras, no caso desta unidade prisional em que realizei as observações, as visitas íntimas precisavam ocorrer de modo clandestino, às escondidas dentro das celas, sob o risco de serem delatadas ou pegas em flagrante e sofrerem punições pela transgressão. A visita íntima pode ser descrita como o momento em 
que a mulher presa receberia seu parceiro dentro da prisão, no qual o casal teria o direito ao contato íntimo, entendido a princípio como relação sexual. Antes da oficialização da visita íntima para as mulheres presas em 1999, através da Resolução número 01/99 do CNPCP, esta era um direito garantido exclusivamente aos detentos. A partir de então, seria obrigação das unidades prisionais garantir o direito a essas visitas ao menos uma vez por mês e a distribuição de preservativos no momento da visita. Na época, havia um projeto para a designação de um espaço fora do prédio onde ficam os pavilhões, dentro do complexo prisional, para a realização das visitas íntimas, mas este não chegou a ser efetivado durante o ano em que acompanhei o cotidiano desta penitenciária. Portanto, segundo relatam as mulheres, os contatos sexuais raramente aconteciam com o uso do preservativo, expondo as mulheres a doenças sexualmente transmissíveis e ocasionando situações de gravidez "após a data da prisão", dentro do cárcere. A questão das mulheres poderem receber companheiras e não companheiros não entrou em discussão quanto à visita íntima oficializada, mas ocorria dentro da rotina clandestina. A visita íntima seria um momento em que as internas poderiam resgatar o senso de privacidade, algo que a institucionalização retira delas. Ao tratar do tema da visita íntima, Lopes (2004) nos diz que

\footnotetext{
(...) a visita íntima é um momento especial em que as mulheres têm a possibilidade de resgatar a intimidade, compartilhar segredos, tratar de assuntos relativos às suas vidas, rever relações familiares e planejar o futuro, não sendo, portanto, apenas uma oportunidade para a prática sexual. (p. 37)
}

A distância dos filhos é apontada entre as mulheres como uma das maiores fontes de sofrimento no dia a dia dentro da prisão, não somente pela saudade, mas também pela falta de notícias sobre eles e a preocupação por não poder estar presente para protegê-los de possíveis situações de perigo. Mostram-se preocupadas também com o exemplo que possam representar para seus filhos por estarem presas, de modo que muitas vezes os filhos se tornam o motivo principal para que as mulheres busquem atividades e trabalho dentro da penitenciária, pro- 
curando mostrar aos filhos que aproveitaram positivamente o período em que ficaram presas. Outro medo que as desesperam é o de que sejam esquecidas pelas crianças, em especial os filhos menores, e que o amor mãe-filho seja deslocado para a pessoa que ficou responsável pela criança no período de cumprimento da pena.

Durante as atividades desenvolvidas em grupo com as presidiárias, notávamos que havia uma vinculação direta que beirava a equivalência entre o que significava ser mulher e o “ser mãe", ou seja, a concepção da maternidade não só como um atributo ou uma possibilidade da mulher, mas como parte da natureza feminina e de seu papel social. Essa associação trazia repercussões não só no modo como compreendiam a si próprias, mas também no relacionamento entre as mulheres presas e no modo como se julgam, criticam e avaliam mutuamente - excluindo ou até mesmo agredindo e ameaçando de morte mulheres envolvidas em crimes contra crianças e contra seus próprios filhos -; no modo como estas mulheres presas eram vistas pelo sistema penitenciário e por seus funcionários; e através dos discursos construídos acerca da prisão de mulheres pela sociedade em geral.

No dia a dia, podia-se notar que o posicionamento da penitenciária com relação a esta vinculação cultural quase direta entre "ser mulher" e "ser mãe" era contraditório. Primeiramente, parecia-nos que as possibilidades existentes para que as presas que eram mães pudessem receber visitas ou conviver com seus filhos eram sistematicamente dificultadas ou negligenciadas de diversos modos. Não havia da parte da instituição qualquer incentivo nesse sentido. Mesmo as crianças que conseguiam comparecer nos dias de visita não encontravam neste complexo prisional um espaço planejado ou preparado especificamente para recebê-las. Por esse motivo muitas mulheres preferiam viver a dor da distância a submeter seus filhos à experiência da entrada na prisão e de encontrá-la naquele ambiente e naquelas condições. Outro motivo relevante para que muitas das mulheres presas preferissem não receber visitas é a intenção de poupar suas crianças dos procedimentos humilhantes de revista impostos até mesmo a elas, pois recaíam so- 
bre estas as desconfianças originadas pelo crime cometido por suas mães. A revista constitui um procedimento de fiscalização altamente invasivo na medida em que não se restringe à buscas feitas apenas nos materiais trazidos ou superficialmente no corpo, mas se desdobra à verificação e o rastreamento do corpo, chegando à inspeção íntima dos genitais. Segundo relatam, haviam procedimentos como a solicitação aos visitantes que se despissem e em seguida realizassem uma espécie de agachamento sobre um espelho no chão, visando verificar a possibilidade de que estas pessoas estivessem portando dentro de seus próprios corpos objetos tais como drogas, armas ou telefones celulares. Ainda que esta verificação fosse realizada por agentes do mesmo sexo dos visitantes, obviamente constituíam-se de situações fortemente constrangedoras.

Entretanto, podíamos observar que estes mesmos contatos e cuidados maternos, tantas vezes dificultados e impedidos, eram cobrados das detentas em seu dia-a-dia. Ocorria a recriminação e o julgamento destas mulheres com relação ao papel materno, tanto entre as próprias presas como por parte dos funcionários das unidades prisionais. Isso acontecia de várias formas, tais como comentários feitos a mim em voz alta de modo que as presas pudessem ouvir; comentários ofensivos e "chamadas de atenção" diretas feitas a elas quando na presença de seus filhos; ou mesmo apontamentos elaborados por parte de profissionais da equipe técnica sob um discurso educacional ou de orientação. Certa vez fui procurada por uma das presas que estava aflita por minha chegada, pois aguardava este momento para saciar uma dúvida. Estava com os olhos marejados que comunicavam desespero e me perguntou:

\footnotetext{
A senhora é psicóloga, não é? É que fui na psicóloga semana passada e ela me disse que agora que meu filho vai ser criado pela minha irmã, vai se esquecer de mim, que vou perder a "função materna”. É verdade? Não quero que ele se esqueça de mim.
}

Ela havia sido acusada de não ter pensado nisto antes de cometer o crime e de, portanto, haver agido de modo egoísta pensando apenas em si e não no que aconteceria aos seus filhos. Curiosamente, o que observamos é que muitas das mulheres apresentam como motivação 
para o envolvimento com o crime a preocupação intensa com seus filhos enquanto, por outro lado, é o sistema prisional quem parece negligenciar o bem-estar das crianças e as consequências para a família do encarceramento destas mulheres, ao oferecer condições nada propícias para a manutenção do vínculo materno.

A escassez de visitas por parte dos entes queridos e amigos relaciona-se também a outra queixa muito frequente entre as mulheres: a dificuldade em obter informações sobre seu próprio processo na justiça. Todas as mulheres ao serem presas tem direito aos serviços gratuitos de um advogado designado pelo estado, exceto nos casos em que optam por um advogado particular quando contam com condições financeiras para isto. Entretanto, ocorre que muitas delas nem mesmo conheceram o advogado público responsável por seu processo; quando perguntávamos a elas se tinham um advogado, muitas respondiam simplesmente que não, pois nestes casos era o mesmo que não ter, ainda que formalmente todas tivessem. Quando as mulheres contavam ainda com visitas e contato - mesmo que por cartas ou telefonemas - com amigos e parentes, era possível solicitar que estes procurassem pelos advogados e soubessem maiores informações sobre o processo. Mas esta, como vimos, não era a regra na maioria dos casos.

O que observávamos era a falta de informação sobre o tipo de acusação (em quais artigos, por exemplo), quais as datas de audiência marcadas, que tipo de defesa seria realizada e, após a designação da sentença, quais as possibilidades de recorrer ou qual a previsão para a liberação de seus alvarás de soltura. Como raramente havia o contato com o advogado, não existia o momento para narrar como os fatos ocorreram por seus pontos de vista, citar possíveis provas a favor das rés e sugerir depoimentos de testemunhas. Segundo relatam as presas, em alguns casos o próprio advogado faltava à audiência ou não manifestava empenho no sentido de defendê-las. Havia ainda um grande número de mulheres "sumariando", expressão utilizada dentro da cadeia para referirem-se às mulheres que não haviam ainda sido sentenciadas. Este período era permeado por intensa angústia, pois não podiam ainda dimensionar qual o tempo 
passariam dentro da cadeia nem fazer planos, ou mesmo saber se havia alguém cuidando de seu caso ou se estavam "esquecidas" ali dentro. Uma das mulheres presas que frequentemente reclamava desta espera aflita pela sentença procurou-nos em uma das atividades saltitante e sorrindo para comunicar que sua pena havia sido determinada pelo juiz. Pela alegria que manifestava pensávamos que o período de reclusão designado seria curto, mas a mulher havia sido sentenciada a nove anos de prisão. A alegria se dava porque agora era possível saber quanto tempo precisaria permanecer ali e preparar o espírito para o tempo que se seguiria e o dia a dia da cadeia. Algumas vezes o tempo "sumariando" superava o tempo designado pela sentença; em outros, ainda mais graves, a mulher aguardava meses dentro da penitenciária para, no dia da audiência, ser inocentada nos casos em que houve equívoco no momento da abordagem policial, trocas de nomes, entre outros problemas. Lembro-me do caso de Jenifer que aguardava há quatro meses a data de sua audiência acreditando firmemente na certeza de que seria inocentada, já que - segundo conta - não havia participado do crime em questão e era ré primária, sem histórico algum de envolvimento com ações desonestas. Ao contrário, Jenifer passara a vida trabalhando muito e preocupada em ajudar seus familiares com o sustento do lar. Entretanto, seu irmão envolvera-se com crimes desde muito jovem e, na data de sua prisão, estava tentando trazê-lo para casa pois estava envolvido em uma briga na rua por acerto de contas com drogas. No confronto com a polícia seu irmão fora alvejado e faleceu, mas os outros envolvidos foram levados e junto com eles Jenifer também foi presa. A moça conta que na data da audiência ouviu do juiz que este sabia de sua inocência, mas que iria mantê-la presa no lugar de seu irmão pois este era procurado há muito tempo pela polícia e já não poderia mais ser punido pela justiça, pois estava morto. A pena determinada fora a de pouco mais de dois anos por tráfico de drogas, da qual o período em que aguardou a sentença foi abatido, mas que mesmo assim deixará marcas em sua experiência de vida e em sua ficha criminal, dificultando a conquista de empregos ou mesmo a recuperação do anterior, perdido na ocasião da prisão. 
Dentre as queixas mais frequentes na esfera dos relacionamentos interpessoais e afetivos, além da problemática das visitas na prisão já anteriormente discutida, duas eram mais recorrentes: o clima de desconfiança geral entre as pessoas envolvidas no cotidiano prisional, sejam elas presas ou funcionários da penitenciária, e o sentimento de solidão e isolamento no dia a dia. Vamos nos dedicar a tratar estes dois temas nos tópicos a seguir.

\subsection{A constante queixa sobre o sentimento de solidão no dia a dia}

Dentre todos os problemas apontados pelas mulheres presas no cotidiano prisional, apenas este parecia ser realmente compartilhado por todas: o sentimento de solidão. A escolha da palavra "compartilhado" para fazer referência a este sentimento a que todas pareciam vivenciar é curiosa, já que o fato de todas passarem por esta dificuldade não fazia com que ela pudesse ser um motivo agregador entre as mulheres.

Uma parte disso pode ser compreendida pelo afastamento de parentes e amigos durante o período de reclusão e a escassez de visitas durante este tempo. Mas ainda assim, estas mulheres encontravam-se ali todos os dias em grande número, convivendo durante as tarefas rotineiras e trazendo do período anterior à prisão possíveis pontos em comum em suas histórias de vida, de modo que haveria a possibilidade de desenvolverem amizades dentro do cárcere também. A maior parte das mulheres ali presas inclusive apresentavam um perfil parecido: eram jovens, mães, negras ou pardas, rés primárias e condenadas por tráfico de drogas.

O perfil da mulher presa é significativamente diferente daquele do homem preso. Segundo o Relatório sobre mulheres encarceradas no Brasil (CLADEM, 2007), enquanto, de acordo 
com o Censo Penitenciário de São Paulo, 54\% das mulheres presas se declararam solteiras e 12\% separadas, divorciadas ou desquitadas, $56 \%$ dos homens se declararam casados ou com companheira. Segundo o estudo da Superintendência de Saúde e da Secretaria de Estado de Administração Penitenciária do Rio de Janeiro (RIO DE JANEIRO, 2006), consta que no Rio de Janeiro 84\% das mulheres são mães, enquanto somente $66 \%$ dos homens são pais. Para os homens, $88,64 \%$ dos filhos estão com a mãe, enquanto dentre os filhos das mulheres presas, somente $16,3 \%$ dos filhos ficam com o pai.

Há também diferenças no perfil entre mulheres e homens encarcerados com relação aos tipos de crimes cometidos. Segue abaixo uma tabela indicando, segundo o delito cometido, a porcentagem de homens e mulheres presos.

TABELA 1 - Porcentagem de homens e mulheres presos no Brasil segundo o delito cometido

\begin{tabular}{lll}
\hline Crime & Homens & Mulheres \\
\hline Tráfico (Lei 6368, Art. 12 e 18) & $13 \%$ & $40 \%$ \\
Roubo (simples e qualificado) & $30 \%$ & $21 \%$ \\
Furto (simples e qualificado) & $12,6 \%$ & $7,4 \%$ \\
Homicídio (simples e qualificado) & $11 \%$ & $6 \%$ \\
\hline Total de homens 306.240 & & \\
Total de mulheres $\quad 13.703$ & & \\
\hline
\end{tabular}

Fonte: DEPEN, novembro de 2006.

O Relatório sobre mulheres encarceradas no Brasil (CLADEM, 2007) aponta ainda que segundo o DEPEN - Departamento Penitenciário Nacional - a maioria das mulheres é primária (72\%), enquanto 44\% dos homens declararam ser reincidentes quando entrevistados. Há também diferenças no perfil quando levamos em conta a faixa etária de homens e mulheres encarcerados. Segue abaixo tabela desenvolvida no Relatório sobre mulheres encarceradas no Brasil com as idades e porcentagem da população feminina e masculina. 


\begin{tabular}{|c|c|c|}
\hline Faixa etária & Homens & Mulheres \\
\hline 18 a 24 anos & $34 \%$ & $26 \%$ \\
\hline 25 a 29 anos & $27 \%$ & $23 \%$ \\
\hline 30 a 34 anos & $17 \%$ & $19 \%$ \\
\hline 35 a 45 anos & $16 \%$ & $22 \%$ \\
\hline 46 a 60 anos & $6 \%$ & $8 \%$ \\
\hline Mais de 60 anos & $1 \%$ & $>1 \%$ \\
\hline Total de homens 214.951 & & \\
\hline Total de mulheres 10.649 & & \\
\hline
\end{tabular}

Fonte: DEPEN, novembro de 2006

Ainda para nos auxiliar a compor o perfil da mulher brasileira presa, sabe-se que em sua maioria (54\%) as mulheres brasileiras presas se declaram negras ou pardas (afro-descendentes), porcentagem esta maior que a de $42 \%$ mulheres negras e pardas na sociedade brasileira em geral, e que com relação à escolaridade, $65 \%$ ou são analfabetas ou não possuem o ensino fundamental completo. Estes dados nos dão a pensar sobre a trajetória de vida destas presas que possivelmente compartilham históricos de desigualdade e humilhação bastante semelhantes, levando-se em consideração não somente o signo de gênero como também os de classe social e cor que carregam. Considerando-se tais características em comum em suas experiências de vida, que poderiam funcionar como fonte de identificação e como elemento agregador, por que então haveria este sentimento de solidão unânime? Não existiriam solidariedade, amizade ou companheirismo dentro desta penitenciária feminina?

Em suas queixas, o que estas mulheres de fato descreviam era um grande distanciamento entre elas quanto aos relacionamentos interpessoais, permeados principalmente por sentimentos de medo, solidão, isolamento e desconfiança. Quando perguntamos qual a opinião destas mulheres sobre os motivos desse ambiente de desconfiança generalizada, a resposta mais 
comum é a de que "mulheres são todas falsas, invejosas e fofoqueiras". Apontam por exemplo que, diferentemente do que ocorreria nas prisões masculinas - onde existiria a reivindicação por direitos para todos igualitariamente, desde os que detêm melhor condição financeira até os que não têm condição alguma, independentemente do apoio à facção criminosa principal no local - na penitenciária feminina existiria sempre uma competição por privilégios e poder, diferença esta explicada pelo modo de ser da mulher ou uma natureza feminina. As mulheres relatavam ainda se ressentirem bastante com esta percepção de que as relações interpessoais são pautadas pelo "cada um por si" e que o valor de cada pessoa era dado pelos bens materiais e o poder que detém dentro da cadeia. Estes contatos interpessoais, diziam elas, eram mediados constantemente por relações de troca, de modo que raramente algo era feito em prol do outro sem que houvesse algum benefício direto associado a esta ação. Mesmo a reivindicação de direitos ocorria de modo individualista e autocentrado. Deste modo, aquelas que não contam com bens materiais ou alguma forma de poder têm pouca força de troca, passando assim por muito mais dificuldades em relação às que contam com estes benefícios.

Segundo relatam, na prisão a confiança em outras pessoas ou a demonstração de que se precisa delas de alguma forma pode torná-las vulneráveis, pois as expõe a cobranças de favores em retribuição, decepções e a traições. Ser sensível ao sofrimento das outras e colocar-se como alguém de confiança oferecendo algum tipo de solidariedade ou ajuda também as fragilizaria por oferecer o risco de serem exploradas e "feitas de bobas" por pessoas mal intencionadas que se acomodariam e abusariam deste auxílio. Diante deste cenário alegam que precisam escolher entre as poucas possibilidades que se oferecem: adaptar-se a este sistema agindo em beneficio próprio apenas, isolando-se e buscando não se envolver emocionalmente ou manter uma postura mais empática e solidária diante das colegas assumindo os riscos declarados desta escolha - a saber, poder ser enganada, tratada como tola e até mesmo ser classificada hierarquicamente no grupo como pessoa mais fraca, de menor valor e poder. 
São raros os momentos em seu cotidiano em que encontram espaço para demonstrar emoções, rir, brincar, chorar. Estas demonstrações podem ser vistas pelas colegas como demonstração de fraqueza e infantilidade, com relação aos choros, ou descaso com o sofrimento das outras, no caso dos risos. Neste contexto, resta também pouco espaço para compartilhar vivências anteriores à prisão ou preocupações e expectativas com a vida depois da prisão. Certa vez contou-me Silvia durante uma conversa:

\footnotetext{
Aqui dentro, sou muito querida por elas. Procuro ajudar como dá, elas desabafam comigo, pedem opinião. Quando precisam, eu faço uma oração, ensino artesanato. Ajudo as analfabetas a escrever cartas. Mas normalmente o assunto não sai da cadeia, os assuntos giram em torno daqui. Por isso também não conto minhas coisas para elas. Há muita falsidade. Por isso ouço mais do que falo. Dou atenção quando elas precisam desabafar, mas quando começam com assuntos que amanhã podem ser distorcidos eu já corto.
}

Os momentos em que realizávamos coletas de dados através de entrevistas individuais eram situações muito carregadas de medo, preocupação, mas também de grande alívio e abertura para confiança após longos períodos de silêncio. Isto porque, naqueles breves espaços de tempo, era possível retomar e relatar um pouco de suas histórias pregressas e emocionarem-se, rirem ou chorarem, sem o temor de verem suas histórias transformadas em algo que as pudesse ferir ou manipular. Era comum que as mulheres deixassem escorrer lágrimas pelo rosto durante suas narrativas, para logo em seguida enxugá-las com gestos bruscos com as mãos, olhando ao redor para verificar se alguém as tinha visto chorar.

Sennett (2000, p. 169) discute o medo da dependência a partir do âmbito profissional mostrando a oposição que costuma ser feita entre profissional dependente como "fraco" e o profissional independente como "forte". Segundo ele, a vergonha da dependência põe em evidência o enfraquecimento dos laços de confiança com o outro e o prevalecimento das defesas nos modos de relacionamento. Ao mesmo tempo, colabora para corroer ainda mais a confiança e o compromisso mútuos, o que põe em risco o estabelecimento de qualquer empreendimento 
de caráter coletivo. Isto ocorria entre as detentas e colaborava para um entendimento da experiência da prisão como resultado apenas de falhas individuais e de deficiências de caráter pessoais. A presença da facção criminosa hegemônica nesta penitenciária também interfere na questão de duas maneiras. Primeiramente pela restrição que a liberdade de expressão das mulheres sofre, limitando a comunicação espontânea entre elas: até mesmo expressar opiniões no contexto prisional pode ser sentido como potencialmente perigoso, sejam elas abertamente contrárias às regras impostas pela facção criminosa, sejam elas passíveis de serem interpretadas desta forma, o que geraria cobranças e dependendo do caso, punições físicas, a que as mulheres chamavam de "levar peguei". Segundo uma das mulheres presas, um dos principais conselhos para sobreviver que recebeu de uma colega ao chegar na penitenciária foi: "fique muda, ouça menos ainda”. Além disto, a facção, através da fala e da ação de suas participantes, reiterava a todo momento, por meio de frases repetidas nos corredores - "ou corre com nós ou corre de nós" (sic) - e símbolos desenhados nas paredes e roupas, suas regras e hierarquias internas, que se pautam prioritariamente na imposição do seu domínio total e em sua lógica mercadológica perversa na qual os princípios mercantis são levados ao paroxismo. Acima de qualquer lei ou do valor das vidas humanas, vinham a competição desmedida por poder, o interesse individual, o desejo de ganho, o dinheiro e o valor das mercadorias.

Vivendo este cotidiano permeado por sofrimentos de diversas ordens, era muito comum que houvesse por parte das mulheres a idealização da vida que levavam e do mundo fora da prisão. Nutriam a idéia de que no "mundão" - como as mulheres presas chamavam o mundo e a vida fora da cadeia - as pessoas eram mais solidárias, a desigualdade e a maldade eram menores e os relacionamentos interpessoais menos utilitários e mais afetuosos. Com frequência as mulheres contavam sentir saudades das pessoas e dos lugares em que viviam fora da penitenciária, mesmo daqueles de que reclamavam antes de serem presas. A saudade era um sentimento muito doloroso para elas e um assunto que evitavam abordar, mas sempre que o tema surgia, 
falavam brevemente sobre as lembranças de lugares, momentos felizes, pessoas e relacionamentos carinhosos e principalmente de cheiros, sejam de perfumes, sejam de alimentos preparados por pessoas queridas, da casa, dos pertences pessoais. Sentiam falta das companhias de amigos e músicas, de noitadas e da diversão que escolhiam, de namorados ou namoradas e parentes. Havia também a saudade de quem se era antes, dos papéis que exerciam no contato com outras pessoas, na família, o trabalho, na vizinhança, onde quer que seu cotidiano se desenrolasse, a saudade de quem se era para os outros, de ser mais do que uma só, ser mais do que presa. Muitas vezes relatos de saudade da própria liberdade. Quando retomavam suas próprias histórias, frequentemente perpassadas por violências, privações, sofrimentos e riscos, reconheciam que a liberdade no mundão também era restrita, mas ali na cadeia, esta restrição era inegável e inesquecível pois estava representada em todos os lugares, da janela da cela, cruzada por barras de ferro, até o uniforme que usavam, seus horários e espaços de trânsito possíveis, funcionários tomando conta de mais grades e suas chaves.

Observávamos, entretanto, que mesmo neste contexto de isolamento, desconfiança e relações desiguais de poder, muitas mulheres concordavam em participar de atividades que não ofereciam nenhum benefício direto em troca, e também casos em que a solidariedade, amizade e o companheirismo eram possíveis e aconteciam, oferecendo-se como um lugar seguro onde encontrar suporte, conforto e reencontrar suas identidades pessoais, compartilhando sonhos e reflexões, ouvindo e contando suas histórias de vida.

\subsection{A solidariedade possível}

Diante de tantas dificuldades enfrentadas no dia a dia prisional e das situações que relatavam ter enfrentado durante a vida, parecia-me extremamente cruel que relatassem com 
tanta revolta e tristeza a solidão em que viviam e, ao mesmo tempo, acabassem por contribuir na manutenção deste ambiente hostil na tentativa de sobreviverem e defenderem-se dele. Ainda que descrevessem estas estratégias de sobrevivência que precisavam adotar no convívio diário com as outras internas - e que afinal eram justamente ações pautadas pelo medo e pela desconfiança que as apartavam - quase sempre as más intenções, o egoísmo, a malandragem, eram atributos "delas", aderidos às outras mulheres internas identificadas como "as presas". Era bastante comum que usassem expressões que evidenciavam este afastamento que buscava a desidentificação com este papel ao mostrarem-se diferentes das outras, como por exemplo: "Presa é assim, minha filha, não faz nada por ninguém se não ganhar algo em troca", "é assim que elas pensam, elas não querem saber de nada, não têm interesse”.

Esse posicionamento era mais evidente na fala das mulheres que haviam sido presas pela primeira vez. E isto não apenas porque frequentemente expressavam as dissonâncias e as similaridades entre suas expectativas acerca da experiência da prisão, e esta última de fato como vem acontecendo, mas também porque traziam um pouco mais claros no discurso os estigmas que criminosas e presas carregam produzindo esta distância entre "elas" e "nós", no caso os "cidadãos de bem". Em uma conversa, a detenta Simone descreve um pouco desta vivência:

\footnotetext{
Antes de ser presa, eu achava que tinha que pegar todos os bandidos, pôr dentro do Maracanã e jogar uma bomba. Eu achava que bandido tinha que morrer. E hoje eu estou aqui dentro. Há pessoas inocentes aqui. Depois de conhecê-las, independentemente do que fizeram, são seres humanos, eu passei a respeitar a vida. Vejo que elas não tiveram opção ou então não tiveram estrutura. Algumas não tiveram opinião própria, se deixaram levar pelos outros. Acredito que todas deveriam poder fazer alguma coisa que pudesse dar uma razão para a vida que não só o crime.
}

Podemos compreender que, para muitas das mulheres, era difícil identificar-se com as outras presas nesta condição, porque isto implicaria reconhecerem-se agora entre "elas", verem-se como destituídas de suas diferentes trajetórias individuais, modos de ser, e diluídas em uma multidão a que socialmente costuma-se atribuir estigmas de maldade absoluta, falta de 
caráter e perigo. Mesmo mulheres que já tinham histórico anterior de internações em instituições totais espantavam-se com situações em que eram tratadas como um "tipo de gente". Certa vez, discutíamos em grupo o preconceito e uma das participantes, Patrícia, nos contou uma experiência que a tinha marcado muito: na época em que fora presa, havia sido ferida no pescoço em uma troca de tiros com a polícia e precisou fazer e trocar curativos por algum tempo no hospital penitenciário. Em sua última consulta quando foi retirar os curativos, fora atendida por um médico que, segundo conta, não a olhava nos olhos, apenas puxando os curativos sem nenhum cuidado, através de movimentos bruscos. Estava assustada e sem compreender o que estava acontecendo, mas não havia perdido de vista que se encontrava em uma situação em que era arriscado questionar sem moderar ao máximo o tom da voz. Perguntou então a ele com cuidado: “O senhor me desculpe perguntar, mas eu fiz algo para o senhor?”. O médico, indignado e nervoso respondeu: "Foi por causa de pessoas como você que eu perdi meu carro, assaltaram minha casa, que minha família vive com medo!". Patrícia então nos contou: “Eu nem respondi nada, não entendi. Não fui eu quem assaltou ele, não é minha culpa!”. Neste caso, Patrícia não era Patrícia. Era “um determinado tipo de gente”, gente criminosa, perigosa, que não merece tratamento humano. Patrícia desaparece no não-olhar do médico, no tratamento brusco e desumano do seu corpo, fora tomada não como uma pessoa, mas como representante de um grupo todo de pessoas que foi resumido a "um tipo de gente". Nesta direção, alguns autores na sociologia se dedicaram a estudar os sentidos da prisão na atualidade e sua relação com as transformações no modelo econômico vigente e no trabalho e suas consequências nas relações sociais e sensibilidades. Dentre eles estão De Giorgi, Garland e Bauman.

De Giorgi (2006) desenvolve sua hipótese de um regime vigente na atualidade, que ele chamou de um regime de "excesso", e descreve um quadro de processos quantitativos e qualitativos de transformação do trabalho, a que define respectivamente como excesso negativo e excesso positivo. O excesso negativo se caracterizaria por uma progressiva redução do nível de 
emprego da força de trabalho, mas por outro lado um excesso contínuo da produtividade social associado à inadequação dos dispositivos institucionais, ainda atrelados ao modelo fordista de emprego, em garantir o acesso à cidadania social. $\mathrm{O}$ excesso positivo se caracterizaria pelas mudanças nas formas de produção, na composição da força de trabalho e nos processos de subjetividade produtivas, que levariam ao desenvolvimento constante de potencialidades produtivas, de laços de cooperação, de formas de comunicação, mas que permanecem orientadas pela racionalidade capitalista. Esta última, então tornada supérflua neste contexto, ficaria reduzida ao puro comando, mas ainda assim continuando a tudo se impor.

Ao mesmo tempo, mundialmente observamos a transformação geográfica da produção capitalista, que torna global o capital, e estabelece como seu novo território o Império. A grande fábrica tende a desaparecer da metrópole pós-moderna, enquanto desenvolve-se gradualmente a informatização da produção, que reduz o trabalho humano e muda as próprias formas de trabalho. A rede e a cooperação produtiva substituem a linha de montagem. De Giorgi aponta que isto acarreta em uma desvinculação do trabalho de sua relação histórica com um produto determinado e realização localizável no tempo e no espaço pela classe operária para se tornar performance comunicativa, realizada pela "multidão", entidade múltipla, irredutível, não representável e desterritorializada.

Se esta multidão produtiva torna-se múltipla e irredutível e já não é mais passível de ser disciplinada, torna-se necessário então governá-la em sua autonomia pela biopolítica em um plano externo. Sua hipótese é a de que as estratégias voltadas para o controle da nova força de trabalho seriam pós-disciplinares e se convergiriam na formação - do já citado acima - regime de "governo do excesso" através de um controle estruturado como "não saber", ou seja, ocorreria a renúncia a qualquer saber sobre os indivíduos, pois as determinações concretas da multidão escapam a qualquer definição. Assim, podemos dizer que de um regime caracterizado por um processo disciplinar de individualização pontual e precisa descrito por Foucault (1977) em seu 
livro Vigiar e punir, passa-se a uma função de supervisão e contenção preventiva de classes inteiras de sujeitos, reagrupando a diversidade em "classes perigosas". Observa-se a orientação das tecnologias de controle no sentido do internamento através do cárcere "atuarial” e da vigilância na metrópole, apontando para a transição do Estado Social ao Estado Penal - ou seja, a gestão das populações problemáticas se dá cada vez menos por instrumentos de regulação social da pobreza e cada vez mais por dispositivos de repressão penal. Para o autor, a racionalidade atuarial do controle estaria se impondo, não mais se tratando de prender indivíduos criminosos perigosos, mas de gerir uma carga de risco que não pode ser reduzida ao nível de populações inteiras. A tecnologia securitária atuaria como estratégia de controle na medida em que limita, neutraliza e desestrutura estas formas de interação social percebidas como de risco, através da construção de um imaginário de insegurança que mina os elos sociais da multidão. Este regime estabelecido de desconfiança universal impede o reconhecimento recíproco dos indivíduos como parte de uma mesma força de trabalho social e colabora com a construção da diversidade como algo de risco.

Bauman (1999) relembra que a prisão é a forma mais radical de confinamento espacial, o qual vem sendo, em todas as épocas, o principal método utilizado para lidar com setores inassimiláveis, problemáticos e dificilmente controláveis da população. Ele nos diz que o confinamento forçado tem sido há séculos, "uma forma visceral e instintiva de reagir a toda diferença e particularmente à diferença que não podia ser acomodada nem se desejava acomodar na rede habitual das relações sociais" (p. 114). Sua função principal é isolar, reduzindo e diminuindo a visão do outro, o que também acarreta o distanciamento, a tendência a substituir os sujeitos por categorias legais e a tornar irrelevante a singularidade de cada pessoa e cada caso. O autor afirma que um ideal distante dentro desta lógica seria o isolamento total, o qual reduziria o outro a uma pura personificação da força punitiva da lei. 
Atualmente, apesar dos clamores pelos direitos humanos e a resistência a formas violentas de punição, frequentemente ouvimos como resposta aos atos violentos e ao aumento da criminalidade o repúdio à impunidade e a justificativa de que medidas mais rígidas precisam ser tomadas diante da "ousadia dos criminosos". Garland (1995) aborda a importância do reconhecimento destas sensibilidades e dos sentidos que a punição adquire na cultura, apontando que são fatores a serem considerados quando procuramos compreender de que modo determinadas formas de punição são apoiadas ou repudiadas em uma determinada época. Sobre esta convivência entre clamores contraditórios, o autor nos diz:

\footnotetext{
Porque o público não escuta a angústia dos prisioneiros e suas famílias, porque o discurso da mídia e da criminologia popular apresenta os criminosos como 'diferentes', e menos que totalmente humanos, e porque a violência das penas é geralmente sanitária, situacional e de pouca visibilidade, o conflito entre as sensibilidades é minimizada e feita tolerável. (p. 243)
}

Podemos dizer que a mídia neste sentido ocupa a função de incitar os ânimos, aumentar a hostilidade contra os criminosos, instrumentalizando a insegurança e tornando a punição uma questão ideológica. Certa vez durante uma conversa, contou-nos uma das mulheres presas:

\footnotetext{
Na hora que me prenderam fiquei revoltada. Até entrevista eu dei para a imprensa, me disseram depois que passou em um programa de televisão conhecido, que o apresentador me chamou de vagabunda e tudo mais. Ele gritava "tá vendo lá, uma mãe de família, ao invés de estar cuidando dos filhos está lá, traficando. (Carta de Simone)
}

As práticas penais, segundo Garland (1995), também atuariam no estabelecimento de limites e na delineamento dos tipos de conduta individuais que são aceitos nas relações sociais, oferecendo um modelo básico para a compreensão das outras pessoas e dos indivíduos a si próprios. As questões envolvidas no crime, na violência e na punição mobilizariam conflitos compartilhados por todos os indivíduos entre os instintos e a repressão destes ao longo de seu desenvolvimento como sujeitos. Desse modo, coexistem sentimentos de compaixão ou indife- 
rença, posicionamentos que reconhecem a ineficácia da prisão em recuperar os criminosos e sua tendência a formar reincidentes e reivindicações indignadas e fervorosas de que a única solução é o endurecimento e a implementação de punições mais severas aos criminosos.

Havia situações em que existia um consenso entre as detentas sobre precisarem ajudar e apoiar umas as outras, independentemente de quem fossem as pessoas envolvidas, individualmente. O principal problema na qual a solidariedade era inquestionável era a da saúde. Se uma das presas ficava doente ou sentia-se mal, as outras mulheres que estivessem por perto se mobilizavam primeiramente para solicitar ajuda e atendimento médico através das agentes penitenciárias e, em um segundo momento, em socorrerem a colega da forma como fosse possível. Por exemplo, se durante a noite uma das presas sente-se mal dentro da cela, a colega que divide o espaço com ela irá começar a gritar e a fazer barulho chamando agentes que possam socorrê-la. Neste tempo, as outras mulheres de outras celas, ao ouvirem-na, começam também a fazer barulho e a chamar por atendimento.

Muitos foram os casos em que pude observar o apoio dado entre as próprias mulheres presas a alguma delas que sofresse uma crise epilética dentro do pavilhão, contendo fisicamente a colega para evitar que esta se machucasse ao se debater, algumas vezes emprestando alguma medicação sua para epilepsia receitada dentro da prisão, e também acolhendo emocionalmente a mulher em sofrimento após o término da crise. Infelizmente, as crises epiléticas pareciam não ser reconhecidas em sua gravidade e urgência pelos funcionários, que muitas vezes assistiam impassíveis a tudo que acontecia, afirmando que este era um evento que se repetia muito frequentemente e que não acarretava maiores desdobramentos.

O momento de despedida de alguma das mulheres presas que recebesse seu alvará de soltura também costumava ser celebrado não importando quem fosse a mulher que estivesse indo embora, ainda que não fosse um consenso do mesmo modo que a questão da saúde. Nas despedidas, eventualmente conflitos pessoais acabavam interferindo, mas a regra era a solida- 
riedade e não a hostilidade neste momento. Houve uma das despedidas a que pudemos assistir em que a mulher que saía da prisão era uma das internas mais queridas daquele pavilhão, tendo passado um longo período nesta penitenciária até a chegada de seu alvará. No momento em que esta presidiária saía do pavilhão e caminhava pelos corredores em direção à saída, todas as outras presas lotaram as escadas e locais vagos pelo caminho e iniciaram um canto de teor religioso, desejando a ela proteção nos novos caminhos. A música ecoava no pavilhão e emocionou profundamente a mulher recém-liberta, assim como a todos que puderam assistir.

Os grupos religiosos costumam ser também um espaço em que as mulheres podiam conviver umas com as outras em outro modelo de relacionamento, sem que precisassem expor necessariamente suas vidas pessoais e pregressas, sem desigualdade de poder entre as participantes - naquele momento específico todas eram iguais - e onde podiam retomar juntas esperanças para o futuro de uma vida melhor e diferente das que haviam vivido antes da prisão.

Nestes momentos e espaços de solidariedade e de convivência possíveis, a confiança mútua não entrava em questão de modo central, pois a proximidade entre as pessoas era mediada principalmente por esta concepção de igualdade entre as envolvidas, independentemente de quem fossem individualmente e do quão plurais fossem suas experiências e posicionamentos diante da vida. Entretanto, como veremos a seguir, havia casos e situações em que as presas, mesmo neste contexto de desconfiança e temores, arriscavam-se viver formas diferentes em muitos aspectos desses outros citados acima: a amizade.

\subsection{Amizade: possibilidades e restrições}

Dentro da penitenciária, as mulheres que estavam presas ali chegavam com idades, histórias, opiniões e graus de envolvimento com o crime bastante diversos, e viam-se obrigadas 
a conviver proximamente por longos períodos de tempo. Como já explicitado anteriormente, apesar desta proximidade física, relatavam um grande distanciamento nos relacionamentos interpessoais, nos falavam sobre fortes sentimentos de medo, solidão, isolamento e desconfiança e descreviam o perigo existente em expressar opiniões no contexto prisional. Entretanto, observávamos no dia a dia que, mesmo havendo restrições e impedimentos de diversas ordens ao estabelecimento de vínculos de confiança, ainda assim a amizade encontrava espaços para ser cultivada e florescer.

A amizade surge principalmente como uma forma de elaborarem as aflições compartilhadas dentro da cadeia, encontrando espaço para falarem e ouvirem sem medo de consequências perigosas, para expressarem sentimentos e manifestarem empatia com a emoção alheia, ambos fortemente evitados por serem cercados de julgamentos dentro da prisão. A amizade oferece-se como um importante elemento agregador, pois faz prevalecer esforços de conciliação, paciência e tolerância, ao invés da ruptura, constituindo-se inclusive como gesto de resistência ao isolamento e às relações superficiais e de curta duração oferecidas mais frequentemente como possibilidade na cadeia. Busnardo (2007), em sua dissertação de Mestrado descreve a amizade como

\footnotetext{
Um vínculo subjetivo fundado no desinteresse pessoal e no encontro não identitário que, embora amparado e também composto por interesses comuns, supera o intercâmbio matemático de afetos e se enraíza numa busca compartilhada e na consideração do outro em si mesmo. A amizade depende de um encontro para acontecer, um encontro no qual o outro não é visado como objeto ou como somatório de características, não é apreendido por suas qualidades, onde o outro não é desejado para a aquisição de determinados fins, para a obtenção de prazer ou satisfação. O encontro da amizade é aquele que depende da abertura que pretenderá somente acompanhar a revelação de alguém e estabelecer comunicação não utilitária, uma comunicação que anseia a troca em si mesma. (BUSNARDO, 2007)
}

Deste modo, as amizades escapam do regime de mercadoria de que as mulheres se queixavam e que, segundo elas mesmas, tentava se impor a todas as formas de relacionamentos humanos dentro da prisão. 
O convívio entre as mulheres, quando fundado na amizade, pode também ser campo para o florescimento do narrar, na medida em que encontram uma na outra a escuta atenta às suas experiências, histórias e lembranças do tempo anterior à prisão - lembranças estas que tão raramente são retomadas ou compartilhadas por medo ou porque trazem também dor e saudade -, tanto oferecendo a possibilidade de encontrar novos sentidos na experiência do cárcere, recolhidos de outra época, quanto vivenciar uma experiência desalienadora ao escutar as memórias de uma amiga. Ambas podem, ao retomar o contato com o passado, repensar e re-significar seu presente, assim como prepararem terreno para construir e reconstruir projetos futuros.

O exercício de narrarem suas histórias de vida faz reviver vozes e imagens que podem se apresentar como um modo de ir alinhavando os fios da existência, dando sentido às experiências vividas, reafirmando o vínculo com suas interações com o mundo, delineando um passado e um contexto existencial, e criando um campo para o encontro de pessoas e experiências semelhantes, mas também diversas às suas próprias. Faz-se assim um apelo à sua memória, o que propicia o estabelecimento de um sentido de unidade e de continuidade, e constrói uma ponte que assegura o vínculo entre o sujeito e suas experiências, restituindo importância ao seu passado e redescobrindo sua identidade. O sujeito pode então passar a reatar elos entre um relato individualizado e uma participação histórica no coletivo e compreender a prisão em sua história não apenas como decorrente de uma escolha ou falha individual somente, mas como um evento enredado em um contexto mais amplo sócio-cultural.

Narradoras e ouvintes juntas constituem assim uma nova história, transformando o período da prisão em uma experiência de vida que não se resume à espera da conclusão das penas e de um viver em suspenso. Isto pode amenizar o sofrimento gerado pela vivência profundamente desenraizadora da cadeia. Simone Weil (1979), ao conceitualizar o enraizamento, escreve que este é talvez a necessidade mais importante da alma humana. Escreve que o ser humano tem uma raiz por sua participação real, ativa e natural na existência de uma coletividade, participação esta 
que vem automaticamente do lugar, do nascimento, da profissão e do ambiente, de modo que cada ser humano tem múltiplas raízes. Para Weil, aquele que está desenraizado está deslocado do tempo e da história, sem contato com a memória étnica e com a memória cultural de seu povo.

Havia casos em que as mulheres chegavam mesmo a planejar a continuidade da amizade fora do contexto prisional e a oferecer auxílio a outras fora da cadeia, como por exemplo no caso de Sueli e Mirian, que haviam feito um combinado com relação às possibilidade de futuro. Sueli havia sido presa em São Paulo, mas tinha origem goiana, não tendo referência familiar ou amigos aqui no estado de São Paulo. Já Mirian contava com o suporte familiar, este não era muito extenso, mas nunca a abandonara no período da detenção. Nenhuma das duas sabia qual receberia o alvará de soltura primeiro e, por conta disto, combinaram o seguinte: caso Mirian fosse libertada primeiro, esta aguardaria a colega e a ajudaria com informações sobre o andamento de seu processo, já estando do outro lado dos muros. Mas se o que o ocorresse fosse o contrário e Sueli recebesse o alvará antes, Mirian ofereceu a ajuda e o apoio de sua própria família, que já havia sido informada e concordara em acolher a colega assim que esta saísse sem um destino certo de imediato, até que Sueli conseguisse se organizar para voltar para Goiás. Enquanto as duas permaneciam presas a expectativa era grande tanto pelo desejo de que a liberdade logo chegasse, como também pela ansiedade da separação assim como o medo de ficarem sozinhas na penitenciária. Havia uma preocupação nossa também, com relação ao trato que fizeram, pois se não fosse cumprido poderia gerar muitas frustrações e Sueli ficaria praticamente desamparada por um tempo. Mas o que ocorreu foi que realmente Sueli saiu antes e pode de fato ser acolhida pela família de Mirian. Saiu levando uma foto em que as duas aparecem juntas, para mostrar aos familiares da amiga, sendo recebida com muita emoção por eles. Mirian saiu dois meses depois.

Neste contexto, há ações e sentimentos que são muito valorizados entre as mulheres presas, em especial dois deles: a palavra dada e a gratidão. A palavra, como elas mesmo diziam, 
frequentemente era tudo com que podiam contar nos relacionamentos afetivos e também nos acordos que faziam e, quando dada, não era esquecida. Isto acontecia independentemente da importância ou gravidade do fato ou dos combinados e parecia também uma forma de sondar as possibilidades de confiança entre as pessoas. Da mesma forma, a gratidão era um valor reconhecido como positivo, e ajudavam a identificar pessoas que ofereciam a possibilidade de confiança e aproximação amistosa. Quando alguém era ajudada e não manifestava sinais de gratidão, costumava receber menos ajuda das companheiras e era vista como pouco confiável. O compromisso da palavra dada e a gratidão pareciam firmar as bases para a construção das amizades na prisão. 


\title{
CAPÍTUlO 3
}

\section{As narrativas de histórias de vida e as cartas}

\author{
Professora, se lembra de mim? Bem, eu sou a Mariana, mais \\ conhecida como Thomas, fui sua aluna no último projeto que \\ realizaram aqui esse ano. Aqui eu gostaria mais uma vez, parabenizá- \\ los pelo belo projeto, a você e todos que contribuíram com esse \\ maravilhoso trabalho feito dentro de um cárcere. (...) Obrigado por \\ ter feito eu me sentir um ser humano capaz, e independente do lugar \\ que me encontro também sou uma cidadã com direitos e deveres. Eu \\ particularmente adorei muito, aprendi demais com você, pode ter \\ certeza, são poucos que tem atitudes como a de vocês, muitos acham \\ que não temos solução, que somos um caso perdido, vocês acreditam \\ em nós e nos passam confiança. (...) Aí professora, pode acreditar, \\ esse curso mudou meus pensamentos. Antes de conhecê-la, meus \\ pensamentos eram de continuar do mesmo jeito, aí no mundão, mas \\ é tudo ilusão, não tem futuro e nem recompensa, estou cansado [sic] \\ de construir um castelo e por segundos ser destruído. É difícil sair \\ dessa vida mas não é impossível se acreditar, e é isso que eu quero \\ para mim, uma profissão sem risco e digna de uma cidadã honesta. \\ Fernandinha, espero que possamos fazer uma amizade \\ independente das grades, sinto falta de alguém para conversar, \\ eu sou sapeca e tudo mas não consigo desabafar com ninguém \\ aqui, com você foi diferente, você me passa segurança. Adorei \\ ter te conhecido, muito obrigado por tudo. Fico por aqui com \\ muitas saudades suas e ansiosa para revê-la, um forte abraço de \\ uma pessoa que passou a admirar seu trabalho e você também. \\ Vou esperar resposta, me escreve, não me deixa sozinha aqui. \\ - Trecho da primeira carta de Mariana Thomas
}

\subsection{Narrativas e revelações}

Como já dito anteriormente, o meu contato com as mulheres detentas iniciou-se através dos grupos propostos pela organização não-governamental em que trabalhei. Ainda que estes não sejam o objeto de estudo deste trabalho, consideramos importante fazer um breve relato acerca dos encontros em grupo. Estes não somente foram o meio através do qual eu pude iniciar o contato com as presas como também, por sua proposta específica, foram fatores facilitadores da constituição de um terreno fértil para o surgimento dos vínculos afetivos e de confiança, onde as narrativas encontraram espaço para florescerem. 
A divulgação das oficinas era feita dentro dos pavilhões através de cartazes nas paredes e algumas vezes por visitas realizadas pela equipe à escola penitenciária. A escolha em participar era livre, sendo necessária apenas a inscrição, que era realizada junto às presas responsáveis pelos postos culturais que aceitavam colaborar conosco neste processo. Já no primeiro encontro as detentas nos contavam que, ao buscarem essas atividades, o faziam com expectativas diversas, que variavam desde a realização de alguma atividade que preenchesse o tempo, motivadas pela curiosidade, por recomendação de colegas que já haviam participado anteriormente e até mesmo expectativa de que a adesão pudesse trazer algum tipo de benefício tais como o recebimento de materiais escolares e remição de pena. Percebíamos ainda que participar dos grupos era também uma forma de ter controle sobre o que acontecia dentro dos pavilhões por parte da facção criminosa hegemônica, mas isto não ocorria de modo declarado: apenas percebíamos que a presença de uma ou outra participante tendia a intimidar as outras mulheres ou mesmo que esta representante era chamada por seu nome precedido do termo "irmã" (este termo designava as mulheres que ocupavam cargos de comando dentro da facção). Estas participantes entretanto nunca chegavam a explicitar sua função ao grupo e também não recebiam de forma alguma tratamento diferenciado por parte das oficineiras.

Cada projeto durava pouco mais de um mês, realizados semanalmente, em grupos fechados de no máximo 30 mulheres. Estes grupos buscavam se constituir como um espaço de reflexão e vivência de participação, através de oficinas temáticas cujos eixos principais eram violência, gênero e cidadania. Eram propostas atividades dinâmicas e debates que procuravam tanto abordar a situação em que estas mulheres se encontravam naquele momento como também desenvolver a reflexão acerca do sistema penitenciário como parte da realidade social como um todo.

Os grupos ao mesmo tempo em que buscavam discutir quais as possibilidades e limites do exercício da cidadania e da reivindicação dos direitos dentro da prisão também propunham que tomassem um tempo para refletir sobre as reais experiências e vivências que todos nós 
temos como cidadãos ao longo de nossas vidas fora dos muros da prisão, para além dos direitos formalizados e da igualdade assumida como pressuposto a todos. Neste contexto, em especial nos primeiros encontros, muitas das queixas discutidas anteriormente surgiam sobre os fortes sentimentos de medo, solidão, isolamento e desconfiança, assim como os relatos sobre o fato de que confiar em outras pessoas as expõe e fragiliza, colocando-as na posição de serem exploradas. Havia ainda o medo de dizer algo que pudesse trazer represálias por parte da facção criminosa. Apesar disto, estas mulheres vinham participar das atividades e aos poucos começavam a falar com mais liberdade. Com a duração das atividades da instituição dentro da penitenciária, era sabido entre as mulheres que a participação delas nestes grupos nunca havia trazido prejuízos ou problemas a nenhuma delas, não havendo sinais de que houvesse de nossa parte qualquer aliança oculta seja com a direção do presídio, seja com a facção. Isto também contribuía para a constituição destes votos iniciais de confiança que recebíamos, havendo raramente a resistência explícita de uma ou outra participante. Dentre essas raras vezes, lembro-me de um grupo em que, no primeiro encontro, realizamos uma atividade lúdica no qual solicitávamos que as mulheres respondessem perguntas como "se eu fosse um objeto, qual eu seria?", "se eu fosse um animal, qual eu seria e por quê??. Uma das participantes estava inscrita pela terceira vez no grupo, tendo desistido dos dois projetos anteriores antes de concluir o número de encontros. Esta respondeu a pergunta "se eu fosse um objeto, qual eu seria?" afirmando "eu seria um revólver", lançando um olhar intimidador e sarcástico a mim e às outras colegas. Assim essa mulher havia escolhido se apresentar a nós e ao grupo em sua terceira tentativa de participar das atividades. A partir desta resposta, fomos fazendo outras perguntas a ela e ao grupo sem reagir com medo ou repreensão, mas com curiosidade e atenção. Esta mulher pôde desta vez concluir o trabalho no grupo, gradualmente mostrando-se interessada e surpreendentemente - após o primeiro contato combativo - amorosa com as técnicas e com as colegas de grupo. Esta situação nos mostra que as atividades propostas eram potencialmente evocadoras de, entre outros sen- 
timentos, muitos medos e angústias entre as mulheres que escolhiam participar. Mas também nos dá a pensar se, diante de uma resposta diferente em um contexto diferente, outros aspectos e facetas destas mulheres não estariam encontrando vias para serem expressas. Era visível na duração dos encontros que nos grupos e, por consequência, no contato individual conosco pelos corredores, que outras posturas corporais e afetivas, menos rígidas ou contraídas, aos poucos iam discretamente se mostrando.

As discussões dos temas propostos passavam intensamente por rememorar suas experiências intracárcere e suas histórias de vida anteriores à prisão. Ainda que escolhessem falar com mais ou menos detalhes sobre isto, sabíamos que cada encontro era um convite a revisitar estes espaços internos, alguns há muito tempo não visitados no esforço em esquecer que realizavam em seu cotidiano. Era comum que as mulheres entendessem a experiência da prisão como resultado apenas de suas próprias falhas e erros individuais e desconsiderassem outras determinantes envolvidas nisto, como a violência, a negligência estatal, a desigualdade, entre outras, e este ponto de vista era fortemente revisto quando as experiências eram trazidas à tona e discutidas junto com outras pessoas. Aqui podemos dialogar com os escritos de Ecléa Bosi que, ao retomar a obra de Simone Weil sobre o desenraizamento operário, nos diz que a possibilidade de se estar junto e a quebra do isolamento são um bem em si, e talvez o maior dos bens, pois "a fragmentação é a essência da escravidão" (BOSI, 2004, p. 180). Compartilhar estas trajetórias de vida neste espaço era uma oportunidade não só para a atribuição de novos sentidos às experiências como também a percepção de vivências e questões em comum e a solidariedade com histórias diferentes. Essas vivências proporcionaram mudanças que pareciam reforçarem-se mutuamente: percebíamos que ao reconhecerem aspectos positivos em si mesmas podiam também ver características positivas nas colegas; ao se verem reconhecidas no olhar de outras pessoas em suas qualidades, também sentiam-se a vontade para abrirem-se a um contato e 
convívio menos hostil umas com as outras, potencializando características pessoais esquecidas, assim como sentimentos e formas de relacionamento mais colaborativos e afetuosos.

Havia também uma outra atividade que era realizada durante o período em que os grupos aconteciam. Já transcorridos alguns encontros, iniciávamos a aplicação de um questionário individual que visava delinear o perfil sócio-econômico das mulheres que participavam do projeto. Estes dados eram colhidos ao final do grupo contando com a participação voluntária das integrantes. Entretanto, além desta função manifesta, começamos a perceber que o momento para responder os questionários passava a ter outro significado para as mulheres, pois tornava-se um momento ansiado. Ainda que os grupos pudessem trazer algum acolhimento para aflições compartilhadas, a atenção dedicada individualmente a elas proporcionava outra forma de vínculo.

As perguntas remetiam principalmente a informações de suas vidas fora da penitenciária, como trabalhos anteriores, escolarização, número de filhos, além também dos históricos de encarceramentos anteriores, os delitos e os artigos pelos quais aguardavam julgamento ou haviam sido condenadas, a situação em que haviam sido presas, entre outras informações. Raramente ocorria que uma ou outra mulher não quisesse colaborar com o questionário ou o respondesse de modo simples e rápido, de modo a apressar sua conclusão. Era preciso dedicar a esta atividade um tempo razoável ainda que, devido ao contexto em que ocorria, não pudéssemos abrir mão de um cuidado maior com o transcorrer do tempo. Havia horários para as trancas, para o almoço das detentas e inclusive para a nossa partida de dentro do pavilhão.

Como já antes dito, no dia a dia dentro dos pavilhões as mulheres buscavam intensamente evitar pausas entre atividades, evocações de memórias e reflexões sobre a prisão em si. Simone Weil descreve algo semelhante ao referir-se à infelicidade do operário como misteriosa e nos conta que 


\begin{abstract}
Os próprios operários dificilmente podem escrever, falar, até mesmo refletir a esse respeito, pois a primeira conseqüência da infelicidade é que o próprio pensamento se quer evadir; não quer considerar a desgraça que o fere. (...) A dificuldade é, pelo menos, igualmente grande para um antigo operário: é fácil para ele falar de sua primeira condição, mas muito difícil pensar realmente nisso, porque nada é coberto mais depressa pelo esquecimento do que uma infelicidade passada. (WEIL, 1979, p. 156)
\end{abstract}

Nestas entrevistas foi preciso compreender, como assinala Ecléa Bosi, o responder às perguntas do questionário - que exigia revisitar memórias, organizá-las de forma a comunicá-las verbalmente a alguém - como um trabalho destas mulheres. Este pôde acontecer na medida em que uma relação de confiança foi se constituindo na convivência pautada na responsabilidade pelo outro e dotada de uma qualidade única de atenção. Como bem recorda Ecléa Bosi as palavras de Guimarães Rosa, “amizade é conversar desarmado” e, deste modo, ainda que ambas carregássemos signos de classe e de instrução, neste espaço era possível conversar desarmadas destes estereótipos. Nestes momentos acontecia que algumas mulheres se emocionavam, ainda que rapidamente buscassem enxugar as lágrimas que corriam olhando de modo vigilante ao redor para certificarem-se de que não foram vistas. Alegrias também eram manifestadas, sorrisos e gargalhadas muitas vezes surgiam, mesmo que em seguida fossem abafadas ou disfarçadas. A entrevista para os questionários era então um espaço para poderem se emocionar sem que isso trouxesse implicações negativas ou julgamentos a elas.

Havia também muitos lapsos de memória durante as narrativas, dados básicos ou trechos inteiros de episódios que não conseguiam recordar ou que recordavam mas não conseguiam contextualizar no tempo junto a outros. Ficavam surpresas ao perceberem que, narrando as experiências, estas não faziam sentido dentro de uma cronologia linear. Outro motivo de espanto eram as situações em que a memória evocada mostrava uma característica ou uma maneira de ser que esta pessoa não mostrava mais dentro da prisão, seja por cuidado e proteção ou por retraimento e tristeza, como afetividade ou fragilidade, apelidos ou chamamentos por parte 
de parentes e amigos queridos, papéis que declaravam exercer antes. Havia uma mulher que dentro da penitenciária adotara um nome, uma aparência e trejeitos masculinos e mantinha um relacionamento homossexual com outra detenta; costumava mostrar, durante o grupo que participava, uma tatuagem que tinha no braço com o nome de duas crianças, uma delas sua filha biológica e a outra filha de criação. Contava que escrevia a elas sempre que podia dizendo "o pai logo estará de volta" ou "o pai ama muito vocês". No dia em que esta participante respondia ao questionário individual, estava mergulhada em memórias dos filhos, sorria com o olhar perdido em outro lugar e em determinado momento, disse a principio sem se dar conta: "era a coisa que eu mais gostava de escutar pela casa, aquele 'mãe, mãe!'”. Logo em seguida deteve a fala e por alguns segundos permaneceu com o olhar distante intrigada. Depois disse rapidamente, "mãe, mãe, ou pai, pai, tanto faz!", e deu prosseguimento ao que relatava, mas a mudança na expressão de seu rosto denunciava que aquele instante não havia passado despercebido, deixando algum estranhamento que não quis explicitar durante a entrevista.

Em algumas vezes notávamos que as mulheres iam progressivamente se apercebendo da dimensão do sofrimento pelo qual passaram durante suas trajetórias de vida enquanto falavam, como se ao narrar pudessem tomar distanciamento de suas histórias e só então compreender as determinantes envolvidas em suas escolhas e experiências. Após uma aplicação de questionário, uma jovem de 23 anos presa pela terceira vez naquela data - mas que relatou ter passado também quase toda sua infância e adolescência em instituições totais como abrigos e a fundação Casa -saiu da entrevista como era de costume, saltitante pelo pavilhão, em seu modo de ser ainda bastante juvenil ( inclusive me chamando de professora ou "profis"). Preocupara-me naquele momento que, diante de tantos sofrimentos que havia narrado há pouco, esta moça aparentemente não desse conta de quantas dores já havia vivido em tão pouco tempo de vida, quase como se aquela história não fosse sua. Na semana seguinte, de volta ao pavilhão sou chamada no corredor por esta mesma moça que me diz, quase de passagem por mim, e em tom de segredo: 
“Oi, profis (sic)! Sabe, andei pensando muito esses dias. Eu tenho só 23 anos, e essa já é a minha terceira cadeia. É muita coisa...”. Em seguida continuou caminhando em frente sem se despedir de mim, mas sem saltitar mantendo passos rápidos e determinados. Não parou para falar com ninguém até entrar em uma das celas. Podemos pensar que rever e compartilhar com alguém sua trajetória de vida pôde tornar todas as dores anteriores relevantes também para ela própria na medida em que foram tomadas como importantes por outro alguém interessado e atento.

Havia também no questionário uma pergunta relacionada aos planos que eventualmente tivessem para após a saída da penitenciária: “você sabe onde vai morar quando sair daqui?”. Esta questão poderia ser respondida brevemente com um sim ou um não, mas o que ocorria frequentemente é que ela apenas desencadeava uma série de reflexões acerca do futuro destas mulheres. Muitas preferiam não fazer planejamentos, apenas esperando encontrar após sua saída tudo como estava antes, retomando a vida lá fora como se ela estivesse estagnado aguardando seu retorno. Outras não planejavam pelo motivo inverso, pois sabendo que muitas mudanças haviam ocorrido - abandono do companheiro, filhos pequenos sob o cuidado de outras pessoas, a perda do emprego anterior e o agravante da passagem pela prisão para conquistar outra posição, entre outras mudanças - optavam por lidarem com os problemas apenas quando já estivessem mais próximos e urgentes. Quando falavam sobre planos, algumas vezes o que diziam parecia-se com um discurso padrão, aceito socialmente, mas que não lhes pertencia e não era pautado em nada concreto, tais como o da busca de uma vida honesta ao invés de uma vida de crimes. De fato, havia muitos impedimentos práticos para que pudessem fazer planos para o futuro enquanto estavam presas; entretanto, em alguns casos, poder narrar e atribuir novos sentidos para suas histórias de vida parece ter fomentado sonhos e objetivos que nunca antes puderam figurar em seus horizontes de possibilidades, tais como cursar uma faculdade, prestar concursos, ou formar parcerias com outras colegas para abrir um negócio. Uma das participantes começou inclusive a direcionar ações no sentido de aproximar-se mais do seu objetivo, 
a saber, formar-se como assistente social. Voltou a estudar e começou a procurar informações na biblioteca e com as colegas e funcionários sobre os caminhos existentes para conseguir a autorização para cursar a faculdade já desde dentro da penitenciária, sabendo que houve um caso bem-sucedido semelhante dentre os homens presos há pouco tempo. Aqui retomamos as palavras de Ecléa Bosi,

O passado reconstruído não é refúgio, mas uma fonte, um manancial de razões para lutar. A memória deixa de ter um caráter de restauração e passa a ser memória geradora de futuro. (...) O limite pra o qual tende a memória narrativa é a transição da nostalgia para um "horizonte de espera", na feliz expressão de Paul Ricoeur. (BOsI, 2004, p. 66)

Talvez mais do que potencializar a elaboração de planos de vida imediatos, estas conversas, as amizades construídas e estes reencontros com sonhos e aspectos individuais frutíferos - a serem cultivados no convívio com as outras pessoas - tenham de fato empenhado um trabalho de preparo de terreno para o renascimento da esperança, onde esta parecia não mais brotar.

\section{2 $\mathrm{O}$ caminho percorrido pela pesquisadora rumo a outro nível de proximidade}

A ideia desta pesquisa foi posterior ao início do meu contato com as mulheres presas nesta penitenciária, que ocorreu enquanto me encontrava no papel de oficineira (e não de pesquisadora). Durante as atividades que realizávamos com elas, surgiam em mim inquietações diante dos sofrimentos que elas desvelavam no dia a dia, as formas com que lidavam com eles e aspectos seus que escolhiam mostrar ou ocultar, muitas vezes de modo surpreendente. No convívio diário compartilhávamos experiências, ocorriam mudanças nas falas, olhares, posturas e gestos, o cotidiano e as relações pessoais eram permeados de contradições e movimento, escapando a qualquer estereotipia, classificação ou previsibilidade. A partir deste contexto o tra- 
balho começou a ser concebido: da necessidade de, após vivenciar intensamente o contato direto com estas pessoas, poder registrar as observações, as histórias ouvidas, tornar comunicável o percebido em proximidade e oferecer algumas reflexões que pude realizar. Nasce então também o olhar da pesquisadora.

Ao estabelecer os primeiros contatos com as mulheres ficava claro na forma de chamar que ocupávamos papéis diferentes muito diferentes naquele espaço. De início, ainda que chamássemos a todas as mulheres por seus nomes próprios - ou de acordo com a preferência pessoal, pelos apelidos adotados -, éramos chamadas invariavelmente por elas de "senhoras". Os termos "senhor" e "senhora" eram usados pelas internas como um chamamento para todos os funcionários e profissionais que realizassem algum trabalho dentro da penitenciária, assim como políticos ou representantes em altos cargos de alguma instituição que visitassem a unidade. Ficavam assim definidos os dois papéis possíveis de serem ocupados na prisão, o de "presa" e o de "senhor/senhora", que na perspectiva das internas evidenciavam o que Oliveira (1999) descreve como a separação entre "nós" e "eles":

\footnotetext{
Entende-se melhor, diante da complexidade das relações em pauta, o sentimento de desconfiança que, entre os oprimidos, separa o "nós" do "eles", ou seja, o mundo dos patrões, dos funcionários públicos, dos policiais, dos professores, das autoridades constituídas com quem se relacionam. Não é difícil à classe oprimida distingui-los; basta lembrar, com Richard Hoggart, a cáustica 'experiência das esperas nas repartições do desemprego, no médico, no hospital'. (OLIVEIRA, 1999, p. 54)
}

Era evidente que, independentemente do vínculo que ali pudéssemos desenvolver, naquele encontro ambos os lados carregavam em sua trajetória, em seu modo de vestir e de falar, e por fim no papel que ali ocupávamos, signos de classe, de status, de instrução. Busquei que estas diferenças não fossem ocultadas, disfarçadas. Não houve de minha parte tentativas de parecer algo que de fato não era, me fazendo passar por ou tentando de alguma forma fazer parte do "nós". No dia a dia, começava a se configurar o convite a experienciar uma relação de outra 
natureza na qual o outro, mesmo em sua diferença, pode aproximar-se e até mesmo estabelecer laços de afeto.

Apesar de todas as desconfianças existentes, estas mulheres vinham aos grupos e às vezes me procuravam individualmente, a princípio pedindo algo como materiais escolares ou informações sobre seu processo jurídico e depois simplesmente para conversar. Surpreendia-me esta abertura que no contexto oferecido parecia improvável. Esta abertura portanto era também uma pergunta, um pedido de posicionamento, de uma resposta diante dela.

O fato de não pertencer nem ao "nós" e nem ao "eles" me possibilitou ocupar este lugar em que o potencial como "alguém em quem confiar" ainda não era claramente definido ou não estava ainda reduzido pelas determinações já discutidas anteriormente. Além disto, a convivência nos grupos proporcionava a partilha de opiniões, experiências e sofrimentos (antigos e presentes) em encontro com uma escuta atenta e respeitosa. Todas ali comungavam da experiência do sofrer e da prisão; me foi possível também estar sensível e compartilhar destas aflições naquele contexto - permanecendo junto a elas naqueles momentos em grupo e em outros do cotidiano.

No transcorrer do tempo, a forma de chamar por "senhora" que ocorria de forma natural começava a gerar estranhamento entre as participantes nos grupos e também consigo próprias assim que diziam o termo. Algumas vezes eram corrigidas por colegas, outras vezes substituíam-no por “professora” e, por fim, perguntavam repetidamente qual era o meu nome e começavam a experimentar chamarem-me por ele.

A aplicação dos questionários individuais passava neste período a representar um marco tanto para elas quanto para mim. Após algum tempo de convivência cotidiana, ali estávamos reunidas, ambas sentadas no chão do corredor do pavilhão, frente a frente, desarmadas dos estereótipos que carregávamos. Diante da atenção e do real interesse por suas histórias e opiniões, as diferenças eram acolhidas não como uma fonte de distanciamento mas como 
pontos por onde construir pontes. Havia da parte delas a preocupação em me trazer para perto sempre que algo na linguagem denunciasse as diferentes referências culturais, me inteirando sobre costumes, gírias e expressões com as quais eu pudesse não estar familiarizada. Ambas saíamos transformadas desta experiência: elas pela possibilidade de recordarem e narrarem vivências dando-as relevo e sentido; e eu como ouvinte por tudo que com elas pude aprender. Mutuamente, nos reconhecíamos em nossas singularidades que transcendiam os papéis de "presa" e "senhora/professora/oficineira" e os enquadramentos jurídicos e institucionais. Compartilhar aquelas memórias parecia também cumprir uma função integradora, reavivando aspectos dos seus modos de ser que ali precisaram ficar amortecidos ou que simplesmente não encontravam no olhar de outras pessoas reconhecimento. Suas lembranças as reintegravam dentro de uma história humana: vistas não somente em suas escolhas e ações criminosas mas também em seu sofrimento e em sua dignidade humana - ali podiam sentir-se não mais sozinhas. E no estar com o outro e com suas lembranças, um reencontro consigo próprias também era possível, potencializando aceitação de características pessoais, de escolhas positivas para a vida e planos para o futuro renovados pela esperança. Na primeira carta que recebi de Mariana Thomas, esta primeiramente me conta do reconhecimento que recebeu no meu olhar ao dizer: "aprendi demais com você, pode ter certeza, são poucos que têm atitudes como a de vocês, muitos acham que não temos solução, que somos um caso perdido, vocês acreditam em nós e nos passam confiança”. Costa (2000), dissertando sobre a obra de Lévinas nos conta que para este último a violência é "aprisionar todos os entes, diferentes entre si, numa generalização que os condiciona e os condena a 'não poder deixar de ser', a 'não poder ser outro' e a 'não poder ser diferente”' (p. 119). Tratou-se então de um olhar que a podia reconhecer em sua transcendência, ou seja, no fato de que em sua condição de humanidade não há nada que a represente de modo absoluto, que a enquadre em um conceito definitivo. Em seguida, conta que a partir daí pôde vislumbrar 
outras possibilidades de futuro diferentes das anteriores nas quais tudo continuaria como antes, e novas escolhas não eram possíveis, e escreve

\begin{abstract}
Antes de conhecê-la, meus pensamentos eram de continuar do mesmo jeito, aí no mundão, mas é tudo ilusão, não tem futuro e nem recompensa, estou cansado de construir um castelo e por segundos ser destruído. É difícil sair dessa vida mas não é impossível se acreditar, e é isso que eu quero para mim.
\end{abstract}

Por fim, fala sobre si mesma em tom afirmativo, como quem havia se reencontrado com outros aspectos seus diversos da condição de presa e com um gostar de ser quem se é:

\begin{abstract}
Já basta! A discriminação que eu sofro pela minha opção sexual que é formada e não vai mudar, sou assim mas sou muito feliz, não tenho vergonha de ser o que eu sou. Eu só sei dizer que eu amo ser assim autêntico, carismático, simpático, extrovertido, sapeca e brincalhão com as pessoas. Isso eu não vou mudar, são qualidades que eu adquiri com o tempo, sou feliz, acredito que ser assim não é um defeito.
\end{abstract}

Destes encontros restava ainda para mim e para elas o sentimento de surpresa e alegria pelos convites feitos e aceitos reciprocamente a um vínculo de outra natureza, pautado em laços de amizade e respeito.

\title{
3.3 Sobre as cartas recebidas
}

As cartas de que tratarei nesta pesquisa foram todas escritas e enviadas no período final do projeto, que deixou de acontecer por não haver encontrado patrocinadores interessados em investir nele. Sabendo que provavelmente não seria possível dar continuidade ao trabalho, pudemos avisar as presas e de certa forma fazer uma despedida aos poucos com elas, que na época até mesmo realizaram um abaixo-assinado para a manutenção dele. Antes disto, eu não havia recebido ainda nenhuma carta, mesmo que a cada conclusão de grupos deixássemos com as participantes o endereço da instituição onde trabalhávamos, caso desejassem nos escrever. 
Talvez isto se deva ao fato de que, mesmo concluindo os grupos, anteriormente as mulheres ainda podiam nos encontrar nos corredores, falar conosco no dia a dia mesmo não participando mais das atividades. Diante do final do trabalho, era sabido que esses encontros não seriam mais possíveis: não mais trabalharíamos lá e mesmo que desejássemos, também não poderíamos adentrar os pavilhões sem o respaldo institucional como representantes da organização, o que tornava as cartas uma forma necessária de comunicação caso desejassem evitar o rompimento total de contato.

As cartas eram o meio oficial de comunicação dentro da penitenciária. Mesmo proibidos, havia muitos aparelhos de telefone celular em posse das detentas, mas sempre deixávamos claro que não iríamos compactuar com isto e, portanto, não atenderíamos ligações que realizassem para nós de dentro da penitenciária para a sede da instituição em que trabalhávamos. Escrever uma carta dentro da prisão exigia primeiramente a dedicação de tempo e trabalho para conseguir ter em mãos elementos de ordem prática e concreta: era preciso conseguir os materiais necessários, como as folhas de papel, a caneta, envelopes e selos que, assim como outros bens dentro da prisão, eram obtidos mediante trocas por serviços e itens de consumo, como por exemplo os cigarros. Caso esta mulher não contasse com o suporte financeiro da família e não recebesse um bom 'jumbo', conseguir estes materiais poderia demorar mais e exigir maior empenho.

Transpostas as barreiras do acesso ao material necessário à escrita, o ato de escrever uma carta exige por si só, independentemente do contexto em que ocorra, alguns processos de elaboração subjetivos diferentes dos de outros modos de comunicação. Encontramos nos textos de Ana Maria Seraidarian Najjar reflexões acerca da função das cartas como uma forma de comunicação do ser humano consigo mesmo e com o mundo. A partir destas considerações, a autora nos diz que "Escrever é uma atividade que demanda o silêncio inicial para dentro da subjetividade. (...) Exige organizar em símbolos o conteúdo destas vivências”. Deste modo, trata- 
-se de um exercício de entrar em contato com determinados conteúdos subjetivos, elaborá-los dentro de si e em seguida redigi-los em forma de mensagem de modo a torná-los comunicáveis a outro alguém. Em seus próprios depoimentos e relatos, estas mulheres nos contavam o quão doloridos podiam ser esses momentos de silêncios, pausas, e mergulhos dentro de si mesmas e suas memórias naquele contexto. Algo do que pudemos compartilhar durante o período em que convivemos parece ter assegurado a estas mulheres que fazer este mergulho dentro de si próprias já não seria mais uma empreitada tão arriscada e solitária. No vínculo que estabelecemos de respeito e responsabilidade, possivelmente as autoras das cartas sentiram haver ali um lugar onde depositar primeiramente sua confiança para expor suas dores e necessidades e ressignificar suas experiências e lembranças. A partir do reconhecimento no olhar do outro de sua dignidade como ser humano - sem enquadrá-las como vítimas desvalidas de autonomia e escolha nem como representações do mal e da total ausência de caráter - puderam realizar este reencontro, este diálogo que primeiramente ocorre consigo próprias. Quem sabe, começava ali ser possível voltar a ouvir o chamado ao longe das coisas que sabiam amar, um exercício de morte e renascimento como sensivelmente escreveu Sophia de Mello Breyner em seu poema "Hora":

\author{
Sinto que hoje novamente embarco \\ Para as grandes aventuras, \\ Passam no ar palavras obscuras \\ E o meu desejo canta - por isso marco \\ Nos meus sentidos a imagem desta hora. \\ Sonoro e profundo \\ Aquele mundo \\ Que eu sonhara e perdera \\ Espera \\ O peso dos meus gestos. \\ E dormem mil gestos nos meus dedos. \\ Desligadas dos círculos funestos \\ Das mentiras alheias, \\ Finalmente solitárias, \\ As minhas mãos estão cheias \\ De expectativa e de segredos \\ Como os negros arvoredos \\ Que baloiçam na noite murmurando. \\ Ao longe por mim oiço chamando \\ A voz das coisas que eu sei amar. \\ E de novo caminho para o mar. \\ (BREYNER, 1947)
}


Além deste diálogo consigo próprias, as cartas pressupõem a presença de um interlocutor, alguém a quem endereçar estas reflexões e mensagens elaboradas e redigidas. Escrever uma carta representa naquele espaço substituir o abandono e a solidão de que tanto se queixavam no dia a dia pela expectativa do encontro, pelo prazer de saberem-se acompanhadas de alguma forma por alguém em sua travessia de vida.

Recebi ao todo cinco cartas, sendo duas delas da mesma detenta, no período em que ainda trabalhei na instituição. Todas foram respondidas, mas em apenas uma das ocasiões houve uma nova resposta à carta que eu enviara (motivo das duas cartas escritas pela mesma pessoa). Nos outros casos, possivelmente minha correspondência chegou à penitenciária em uma data na qual as destinatárias já haviam recebido o alvará de soltura, já que a maioria delas era ré primária e estava presa por crimes cujas penas tinham curta duração, tais como posse e/ou tráfico de entorpecentes. Neste período em que o projeto se encerrava, continuávamos indo aos pavilhões para concluir algumas atividades remanescentes, e nestas visitas fui abordada algumas vezes pelas mulheres que me escreveram cartas buscando confirmar se eu as havia de fato recebido e se iria respondê-las. Pairava a dúvida sobre o recebimento principalmente porque as cartas que entram e saem da penitenciária passam por uma inspeção por parte da segurança para evitar trocas de informações sobre crimes ou conteúdos que poderiam trazer problemas à instituição, tais como o planejamento de mobilizações, entre outras ações proibidas e ilegais. Por conta disto, poderiam ter seu envio atrasado ou serem interceptadas, não chegando ao seu destino. Contavam as presas que algumas vezes fotos enviadas juntamente com a carta dentro dos envelopes não chegavam em suas mãos ou às dos seus destinatários, sem que houvesse de fato um motivo que justificasse a retirada destas. Deste modo, era grande a ansiedade em confirmar comigo pessoalmente o recebimento e, tendo feito isso, tomava lugar então a espera e a expectativa por minha resposta. 
As cartas apresentavam conteúdos diversos. Em todas elas, havia o cuidado por parte das mulheres que escreviam em decorar a folha de papel com desenhos como estrelas, flores e corações, em algumas delas usando canetas em cores diferentes para dar destaque principalmente ao meu nome e ao nome delas ao longo do texto. Nelas não apenas me chamavam pelo nome próprio, como também por "amiga". Algumas decoravam inclusive o próprio envelope com desenhos de flores e com frases, como ocorreu na carta de Isabel que trazia também o seguinte escrito: “Amizade supera a diferença. Ter amigas é ter confiança, ter paz e ter felicidade. Ter tudo é ter sua amizade, obrigada pela sua amizade”. Assim também o fez Mariana Thomas, que no envelope escreve "Cheguei para ficar".

Os textos das cartas propriamente ditos também começavam com saudações nas quais ficam evidentes o querer bem e demonstrações de amizade. Assim escreve Mariana Thomas : "Olá Fernandinha! Espero que, quando esta humilde portadora de singelos sentimentos cheguem em suas mãos, possa lhe transmitir toda a energia positiva que tenho em mente". De modo igualmente carinhoso Ana começa sua carta, escrevendo: "Saudações, minha amiga! Espero que esta ao chegar a suas mãos possa te encontrar com saúde e muita paz, que a mesma leve a você todo carinho que eu, essa sua amiga, tenho por ti”. Em todas as vezes, puderam expressar saudades tanto dos grupos realizados e das vivências compartilhadas neles, como também de mim. Assim escreveu Jussara em sua carta:

\section{Querida Fernanda,}

Já estou com muitas saudades, não te vi mais aqui na penitenciária. Fê, eu ainda estou aqui, mas tenho fé que ainda esse ano eu vou embora para honra e glória do senhor Jesus Cristo. Fernanda, você não vai mandar a foto que tiramos no dia da festa de encerramento? Estou aguardando a foto e notícias suas, quando vai acontecer o projeto novamente? 
Mariana Thomas também fala de saudades minhas e do grupo: "Fico por aqui com muitas saudades suas, e ansioso para revê-la. Fica com Deus e um forte abraço de um aluno [sic] que não te esquece. Deixo lembranças a todos do Projeto".

Perguntavam também sobre "a rua”, expressão utilizada para falar da vida fora da prisão, expressando não somente o desejo de ter notícias de minha parte como também saudades do tempo que viveram antes de estarem presas e de quem eram nesta época. Nas palavras de Ana,

\begin{abstract}
(...) E você? Me conta as novas da rua, vocês vão voltar pra cá? Olha, amiga, mesmo que nós não nos encontramos novamente saiba que levarei comigo tudo que aprendi no grupo e algumas amizades que fiz neste lugar. Pode deixar que quando eu sair como eu vou levar o seu endereço, eu vou escrever pra te contar como foi o meu encontro com a minha família e aí mandarei uma foto do meu filho Gabriel para você guardar, tá bom? A Rosa, a tia Rita, a Luiza, do grupo, elas estão mandando um abração para você! Tem uma mina [sic] aqui que perguntou como era o projeto, aí eu falei de como que eram as palestras, que eu aprendi muito, que apesar do nosso sofrimento sempre tem uma que está sofrendo mais que a gente, aí ela se animou que disse que gostaria de participar.
\end{abstract}

Mariana, assim como Ana, também escreve sobre as marcas deixadas pela experiência do projeto, a partir do qual diz ter pensado seu passado e também suas escolhas e disso sonhar outras possibilidades de futuro. Assim ela escreve:

Fernandinha, eu refleti muito sobre meus atos, reconheço que errei e infelizmente estou aqui pagando o preço. Mas é tarde, agora o que me resta é me adaptar com o cotidiano e esperar meu semiaberto chegar na casa. Vou sentir saudades de você, espero ter a oportunidade de conhecer o projeto de perto, de encontrá-la de novo, mas não aqui, no mundão, longe do que não traz felicidade para ninguém. Aí professora, pode acreditar, esse curso mudou meus pensamentos. Antes de conhecê-la meus pensamentos eram de continuar do mesmo jeito, aí no mundão, mas é tudo ilusão. (...) É difícil sair dessa vida mas não é impossível se acreditar, e é isso que eu quero para mim, uma profissão sem risco e digna de uma cidadã honesta. Talvez se eu não estivesse aqui, se eu não tivesse feito o curso, essa mudança de caminho não tivesse acontecido.

Algumas vezes, descrevem que estas marcas já se refletem em seu dia a dia, no presente, mudando a forma de ver as colegas e também de organizar sua rotina. Na carta de Jussara ela me escreve, 
Fernanda, eu agradeço a Deus por ter te conhecido, pois eu aprendi muito com vocês, gostei muito dos dias que nos encontramos, aprendi até que tem algumas companheiras boas. Continuo de cela, só saio para ir no culto e nos ensaios do grupo de louvor, e quando não estou estudando a bíblia e no culto ou no ensaio, estou na cela ouvindo os cultos da igreja Internacional da Graça de Deus, fazendo crochê e bordando. Graças a Deus consigo me manter fora das coisas erradas e servir a Deus, pois pretendo sair daqui e voltar a ter a minha vida normal de pessoa honesta, cuidar da minha família e servir a Deus com todo o meu coração e continuar orando por pessoas como vocês que trazem esperança para os nossos corações, mesmo aqui nessa escuridão das trevas. Muito obrigada por tudo que vocês me ensinaram, pois eu creio que já estou pondo em prática muitas coisas que aprendi, ser uma cidadã mesmo aqui nesse lugar, respeitar as pessoas e os seus espaços, amá-las com os seus defeitos.

As mulheres contavam-me também sobre seu dia a dia, o modo como estruturavam sua rotina, dificuldades, desafios e surpresas positivas que vivenciavam no cotidiano. Escrever sobre isto supõe não estar mais suspensa no tempo e em um espaço invisível, poder registrar na escrita e também na memória de alguém sua existência neste período de tempo, deixando também marcas de sua passagem por esta vida. Esta aflição de encontrarem-se abandonadas ou esquecidas dentro da prisão e a solicitação de que eu não as abandone ali sem essa interlocução - que é ao mesmo tempo a ligação com um outro alguém mas também um vínculo que potencializa o diálogo consigo próprias - é expressa nas doloridas palavras de Mariana em sua primeira carta, que tratam de solidão, mas ao mesmo tempo de esperança:

Fernandinha, espero que possamos fazer uma amizade independente das grades, sinto falta de alguém para conversar, eu sou sapeca e tudo mas não consigo desabafar com ninguém aqui, com você foi diferente, você me passa segurança. (...) Vou esperar resposta, me escreve. Não me deixa sozinha aqui.

Diante de minha resposta, ela volta a dizer da importância destes contatos via carta,

e novamente me escreve:

Olá! É com muita satisfação que chego através dessa para expressar todo meu carinho e afeto. Adorei receber a sua carta, Fernandinha, obrigado por ter lembrado de mim. Sabe, eu tenho você como uma amiga já, espero que eu possa vê-la novamente, estou morrendo de saudades de você. (...) Você, Fer, é humilde, não me julga, tá ligado [sic], é difícil encontrar uma pessoa como 
você, muitas tem medo, jamais eu quero o seu mal, e sabe por quê? Porque você é uma mulher maravilhosa com as pessoas, e essa sua atitude acabou me ganhando. Você tem todo o meu respeito, Fer, te adoro, quero poder ser seu [sic] colega. Espero que você não se esqueça de mim, eu estou aqui mas não estou morto [sic]. Achei até que não ia me escrever, falar é muito fácil, né.

Escrever as cartas manifestava ali também um pedido de que eu pudesse ser alguém a quem endereçar suas dores e também me responsabilizasse por este vínculo construído no convívio, assumindo uma posição diante dele e dos discursos que emitia. As cartas respondidas que eu enviava eram uma forma de acolher o que me comunicavam e não as deixar na solidão. Sobre este acolhimento ético, Safra (2005) nos diz que “(...) O terrível é emitir um som sem que ele jamais seja ecoado por outro ser humano, o que significa perder-se em espaços infinitos, aniquiladores de qualquer registro da vida psíquica” (SAFRA, 2005, p. 38 ).

As cartas eram também repletas de pedidos de amparo e proteção divinos endereçadas a mim e à equipe de trabalho do projeto. A religião dentro da prisão era uma importante fonte de esperança, ajudando a atribuir sentidos para a experiência do cárcere e representando também um espaço, compartilhado entre elas nos grupos de oração, no qual se reencontravam com valores a que atribuíam qualidades positivas.

Fe, que Deus abençoe você e a todos que trabalham no projeto. Muito obrigada, que Deus ilumine os seus caminhos, as terei guardadas no meu coração e vocês estarão presentes em minhas orações, que Deus te proteja e te dê muitas vitórias. (Carta de Jussara)

Peço a Deus que não me esqueça. Quero ir embora para cuidar de mim, dos meus filhos, mas aqui olho em volta e só vejo grades, muralhas. Você é muito legal, que Deus possa te abençoar cada vez mais em todos os seus caminhos. (Carta de Isabel)

Bom, minha amiga, por hoje é só, mas logo mais eu escrevo outra com mais novidades. Fica com Deus, que Ele te abençoe, proteja e ilumine seus passos em toda a sua vida. Beijos da sua amiga de hoje e de sempre. (Carta de Ana) 
Por fim, havia em todas as cartas que recebi a manifestação do sentimento de gratidão. Conforme visto no capítulo 2, a gratidão era um valor fortemente reconhecido como positivo no relacionamento interpessoal entre as presas, e sua manifestação ou sua ausência ajudavam a identificar pessoas que ofereciam a possibilidade do estabelecimento de vínculo de confiança e aproximação amistosa. Desta forma, a gratidão era um importante fator que parecia firmar as bases para a construção das amizades na prisão. Em sua carta, Isabel me escreve: "Sei que vocês querem meu bem em qualquer circunstância. O meu carinho e toda a minha gratidão, eu agradeço a vocês por tudo, pela atenção, pelo carinho, os aprendizados. Te adoro, me escreva”. Esta gratidão era mútua: não somente pelo aprendizado, mas pela coragem com que assumiram o desafio de arriscarem-se aproximar e serem vistas em proximidade junto a um outro que a princípio trazia tantos signos de diferenças. Aceitaram o convite de aventurarem-se a perceber para além dos estereótipos e das mediações impostas. Estas mulheres também puderam me reconhecer em minha transcendência sem me reduzirem a papéis e a funções, tornando não somente possível a realização deste trabalho como também que eu renovasse minhas esperanças e me sentisse acompanhada no meu percurso como profissional e como pessoa. 


\title{
Palavras finais
}

\author{
Deixai-me nascer de novo, \\ nunca mais em terra estranha, \\ mas no meio do meu povo, \\ com meu céu, minha montanha, \\ meu mar e minha família. \\ E que na minha memória \\ fique esta vida bem viva, \\ para contar minha história \\ de mendiga e de cativa \\ e meus suspiros de exílio. \\ Porque há doçura e beleza \\ na amargura atravessada, \\ e eu quero memória acesa \\ depois da angústia apagada. \\ Com que afeição me remiro! \\ Marinheiro de regresso \\ com seu barco posto a fundo, \\ às vezes quase me esqueço \\ que foi verdade este mundo. \\ (Ou talvez fosse mentira...) \\ Cecília Meireles
}

Atuar em uma instituição como a Penitenciária Feminina e escrever sobre esta experiência envolveram um contato constante com a dureza da realidade vivida dentro do cárcere e com as memórias e reflexões dolorosas surgidas durante o desenvolvimento do trabalho. Assim como ocorre na elaboração de uma carta, para redigir os capítulos é preciso silenciar e mergulhar para dentro de si, reencontrando passagens, falas, imagens e personagens para então organizar estes conteúdos e apresentá-los de forma compreensível através de palavras ao leitor. Isto implicou na superação, em muitos momentos, da dificuldade em escrever sobre situações que vivi tão proximamente e que ainda me mobilizavam afetivamente de modo tão intenso.

Por outro lado, em mais um paralelo, escrever sobre estas mulheres foi também uma forma de revisitá-las, retomar o contato, elaborando assim um texto que pudesse se constituir como uma "ponte sobre o vale das separações" e minimizar as saudades, como escreveu Najjar (1998) sobre a redação de cartas. Diante de um ambiente tão difícil para se trabalhar como uma penitenciária, é possível que o leitor se pergunte como é possível sentir saudades. 
Enquanto trabalhei com as mulheres presas e depois, ao eleger este tema de pesquisa, não foram raras às vezes em que colegas, amigos e familiares me perguntavam porque escolher um campo de atuação e de pesquisa associados a tantos adjetivos de caráter aversivo tais como "complicado", "perigoso" e "pesado". Tendo antes em meu percurso profissional quase sempre me dedicado a trabalhar com questões delicadas e que envolviam um grau elevado de sofrimento, não era necessariamente um motivo de surpresa que eu trabalhasse com detentas, mas nestas falas sentia quase sempre implícito o sentido de que, desta vez, eu havia passado dos limites, seja quanto ao idealismo de trabalhar com problemas tão complexos e de difícil intervenção, seja com relação ao público escolhido, este tido como não merecedor da atenção recebida e também como um investimento de energia perdido.

Estas impressões me incomodavam muito em especial no princípio, quando a cada dia me aproximava mais daquelas mulheres e conhecia histórias tão diversas. Apesar do sentimento de impotência que constantemente surgia diante de tantas limitações impostas pelo próprio ambiente e pela complexidade das situações que se apresentavam, havia em mim uma grande vontade de ajudar, de poder transformar aquela experiência em algo que, mesmo minimamente, pudesse intervir naquela realidade. Tendo contato assim com uma outra faceta daquele fenômeno e daquelas pessoas, ouvindo tantas histórias de injustiças e sofrimento, de início me vi tentada a incorrer no outro extremo do apontado acima, por parte de quem de fora via a situação: de modo ingênuo e um tanto onipotente, vitimizar estas mulheres e supor que determinadas mudanças pudessem ser trazidas por intermédio de minha intervenção. Lembro-me aqui destas palavras de Pellegrino (1987):

O pobre absoluto não tem porque manter o pacto social com uma sociedade que o reduz a condição de detrito, ao mesmo tempo em que, em seus estratos dirigentes, se entrega à corrupção e ao deboche impune. Ele tem toda a razão de odiar e repelir essa sociedade. (PELLEGRINO, 1987, p. 204) 
Ao longo do percurso, a mesma proximidade envolvida nos sentimentos descritos acima permitiu que gradativamente minha forma de estar com estas mulheres e meu olhar sobre elas ganhassem tons mais realistas e, portanto, repletos das contradições e paradoxos descritos ao longo do texto: nem vítimas indefesas nem vilãs capazes apenas de perpetrar maldades. Este me parece ser um desafio pelo qual não somente eu passei individualmente, como também representa o conflito explícito nos discursos da mídia e frequentemente da opinião pública: o espanto e a revolta diante de maus-tratos trazidos à tona e da declarada falha das instituições prisionais em funcionarem como reabilitadoras versus a crítica ao excesso de tolerância - costumeiramente atribuída aos representantes dos "direitos humanos" - e a solicitação de punições mais rígidas e severas. Souza (2005) aponta que esses embates por si só evidenciam as falhas existentes no próprio funcionamento social diante da violência e da justiça, nos dizendo que

\footnotetext{
Cria-se um falso contraponto presente no ataque aos defensores dos direitos humanos: direito dos infratores, criminosos, prisioneiros versus direito das vítimas. A presença desta falsa dicotomia já é reveladora de uma realidade marcada pela exclusão e pela injustiça. Não se trata de vitimizar ou privilegiar os infratores, mas antes de uma preservação dos direitos e garantias constitucionais; de uma sustentação, no limite do possível, do Estado de Direito.

(...) Outro aspecto dessa dificuldade revela-se no temor de nos vermos no limite do moralismo mais conservador e ingênuo. Punir é vivido como um ato de violência. (...) Sustentar a punição, legitimála, é enfrentar uma série de paradoxos e contradições, mas é tarefa necessária para a sobrevivência na cultura e da cultura. A impunidade espraia no humano, a via para a violência. (souzA, 2005, p. 67-68)
}

Lembro-me de uma situação em que uma mulher participava da atividade pela manhã em grupo comigo quando foi subitamente comunicada que havia chegado seu alvará de soltura e ela seria libertada naquele mesmo dia. Tinha em seu poder uma camiseta que havia ganhado há pouco e, quando recebeu o chamado, pediu que eu guardasse o objeto por ela. Entretanto, esta mulher não retornou até o final da atividade e precisamos partir para o horário de almoço sem que a camiseta fosse devolvida. Retornamos para o período da tarde e estávamos já saindo do pavilhão quando encontramos esta mulher em fila junto a outras presas que 
também estavam deixando a penitenciária recebendo orientações dadas aos gritos por parte de uma agente penitenciária de expressão facial e corporal enrijecida. A mulher ao me ver com a camiseta nas mãos abriu um sorriso e começou a gesticular pedindo a camiseta. Fiz um gesto sinalizando que se acalmasse e que entregaria a camiseta a ela já fora da penitenciária, mas ela não conseguiu conter a ansiedade e correu em minha direção pegando a camiseta. A agente gritou então com ela dizendo que retornasse à fila caso não quisesse passar mais uma noite no pavilhão, tomou a camiseta de suas mãos e em seguida se dirigiu a mim me entregando a camiseta com um gesto brusco e dizendo que saísse dali, pois estava atrapalhando seu trabalho. Assustada e sem conseguir dizer nada diante do ocorrido, fui para o lado de fora do prédio aguardar a saída de minhas colegas de trabalho, quando vi a agente saindo seguida da fila de mulheres recém-libertas rumo ao portão de saída. A funcionária também me viu e atentou para o olhar de feliz ansiedade que a ex-presidiária dirigiu a mim. Deixando-as sob a responsabilidade de outra agente, esta retornou e me disse com o volume de voz aumentado e apontando o dedo indicador para o meu rosto: “você não pode deixar que elas tomem assim as coisas de vocês!”. Então eu respondi "ela não estava tomando de mim, aquela camiseta era dela, eu estava apenas guardando". Mais nervosa do que antes a agente respondeu "vocês acham elas muito boazinhas, têm pena delas, mas lá fora você vai ser a primeira que ela vai assaltar!"; em seguida saiu sem esperar para ouvir o que quer que eu pudesse dizer em resposta. Na saída, entreguei a camiseta a ela, sem maiores protestos por parte do outro agente que as acompanhava.

De fato, com raras exceções, as mulheres que ali estavam haviam cometidos desde infrações com pouca ou nenhuma violência envolvida até crimes bárbaros. Mas haviam também estado do outro lado da história, sofrendo com a violência do descaso estatal e deixadas à mercê da sorte para lidarem com as intempéries da vida. A prisão em suas biografias parecia apenas mais um dos eventos difíceis e das restrições à liberdade que conheceram. O contato com elas me possibilitou enxergar outros aspectos para além das dicotomias citadas acima, não 
somente com relação a estas mulheres como pessoas, mas também a estas separações que, com uma facilidade significativa, fazemos entre "elas" e "nós".

Com esta colocação acima, não quero incorrer no mesmo deslize, apontado anteriormente, em que incorri no início do trabalho e desconsiderar ou perder de vista a escolha que fizeram estas mulheres em determinado momento entre a honestidade e o crime. Gostaria apenas de propor aqui a reflexão de que talvez esta cisão entre "elas", as presas - como representantes das pessoas criminosas -, e "nós", "cidadãos de bem", vivendo uma vida de honestidade, tenha sua raiz mais no que nos torna perigosamente parecidos do que na diferença pura e simples presente na escolha explícita destas mulheres. Esta queixa que traziam acerca do isolamento e da solidão, acrescidas das relações sociais baseadas na lógica mercadológica e individualista, sem perspectiva coletiva e cívica, nos dá indicativos para pensar que no espaço do cárcere aparecem, com cores mais fortes, problemas centrais da sociedade em que está inserido. E que possivelmente assim ocorre porque, na prisão, as formas usualmente encontradas em liberdade para encarar estes problemas estão temporariamente suspensas ou impedidas - a saber, as soluções outras por via individual, que deem conta de problemas que surgem onde o Estado tem deixado seus cidadãos desprotegidos.

Percebemos culturalmente um progressivo esvaziamento dos espaços da vida pública e a supervalorização da vida privada e do conceito de "individualidade". Com frequência reservamos o "estar com os outros" apenas para alguns momentos de nossa vida privada, e pessoas de nosso convívio mais próximo. Conviver com outras pessoas hoje pode nos parecer perda de tempo, chateação ou até mesmo arriscado. Como disse certa vez Jurandir Freire Costa, "pouco a pouco desaprendemos a gostar de gente". ${ }^{2}$ Deste modo vamos ficando apartados mesmo que inseridos em uma cultura de massa e cercados de multidões nos grandes centros 
urbanos como São Paulo. Estes afastamentos tanto entre os indivíduos intersubjetivamente, como também os de natureza geográfica, tais como bairros de periferia e bairros ricos, favelas e condomínios fechados, tornam difícil que as pessoas possam se perceber como parte de uma coletividade, de algo maior que a sua própria existência privada. Para além da evidente desigualdade sócio-econômica que ainda vivemos em nosso país, nem mesmo apreciamos de fato o contato com a diferença, com o que há de singular em cada ser humano. Inseridos que estamos em uma cultura que incentiva o "cada um por si", o que é sofrimento do outro cabe apenas a ele mesmo, na medida em que ele é o único responsável tanto pela dificuldade vivida como por sua superação. Podemos pensar que estas mulheres presas representam casos em que a saída encontrada para lidarem por conta própria com as dificuldades não foi bem sucedida. Quando julgamos que todas aquelas pessoas presas ali chegaram ou por falhas de caráter ou por decisões feitas com base em princípios imorais, desconsideramos um contexto muito mais amplo envolvido nessas escolhas e que nos abarca como participantes desta mesma cultura e ainda como seres humanos. Quando não queremos saber sobre essas pessoas ou reconhecê-las para mais adiante dos estereótipos, estamos evitando enxergar quão profunda ainda é a desigualdade em que todos nós vivemos, o quanto ainda não contamos como cidadãos, mas como consumidores, inclusive daquilo que deveria ser garantido por direito. Estabelecemos assim uma forma de viver no mundo no qual compartilhamos o isolamento, clamamos por direitos apenas quando sua falta nos afeta individualmente, buscamos independência financeira e emocional, mas nos ressentimos da escassez de relações afetivas significativas que escapem da lógica de mercado.

Durante o trabalho, pudemos ver que, por entre as queixas das mulheres acerca do clima de medo e a desconfiança entre as presas, evidenciava-se também a busca por relações éticas pautadas pelo respeito e pela responsabilidade mútua com outros seres humanos. No dia a dia lançávamos eu e elas, iscas-convites para uma forma diferente de relacionamento, para o compartilhamento da vida, da companhia e da solidão. Felizmente, com todas as nossas dife- 
renças, pudemos lá e cá responder a estes chamados, fazer eco às vozes que ali chamavam. $\mathrm{O}$ reconhecimento em seu sofrimento e em sua condição humana - que transcende os papéis institucionais e os rótulos jurídicos - que pareciam buscar através das queixas, encontrou vias simples para tomar curso: a alegria despertada ao ouvir seu nome lembrado meses após o termino dos grupos, pela escuta dotada da qualidade da atenção, pelo envio e o recebimento de cartas. No encontro com o outro, ao lembrarem histórias, pessoas, e dividirem sonhos, uma possibilidade de reencontro consigo mesmas. Najjar (1998) ao tratar das cartas nos diz:

\footnotetext{
Reflito sobre o canto melancólico que ressoa da interioridade do imigrante, do exilado, e de outros grupos que sofreram bruscas despedidas de suas origens. (...) Esse processo dificulta ao imigrante, e a pessoa que sofreu a exclusão da própria cultura, recriar, ou replantar na nova realidade que o abriga, sementes da representatividade própria. Seu canto saudoso é reflexo da saudade que sente de si mesmo. (NAJJAR, 1998, p. 25)
}

Neste encontro com o outro e reencontro consigo mesmas, sonhos que antes não encontravam terreno para florescer passavam a despontar, outros horizontes para o futuro podiam ser desenhados. A despeito das dificuldades vividas antes da e durante a prisão, traziam consigo ainda o germe da esperança para o futuro e a força para sobreviverem diante de condições tão adversas. Nas palavras de Sophia de Mello Breyner Andresen,

\footnotetext{
Apesar das ruínas e da morte,

Onde sempre acabou cada ilusão,

A força dos meus sonhos é tão forte,

Que de tudo renasce a exaltação

E nunca as minhas mãos ficam vazias.
}

Viver com elas estes dias, em que do sofrimento renascia a força para viver, me dava também forças para continuar acreditando no trabalho diante de todas as restrições e desafios à atuação que se apresentavam. Além disto, pude aprender com elas a arte de resistir e continuar, mantendo viva a abertura para o novo e um olhar para o mundo que se nega a se endurecer e se desresponsabilizar por ele. 
Se me chamavam nas cartas por amiga e por apelidos carinhosos, é porque ali naquele espaço de fato pudemos construir laços afetivos. Assim como ocorria todos os dias em que eu deixava a penitenciária após as atividades, encerrar aquele trabalho foi algo muito dolorido de se fazer, sabendo que elas ali permaneciam enquanto eu podia partir. As cartas por um tempo transpuseram os muros e as grades e se constituíram como uma forma de manterem vivos o contato e também a memória do cotidiano compartilhado. Após esse período, estas mulheres também puderam partir e dar prosseguimento às suas vidas, agora do lado de fora, enquanto eu também deixei de ser funcionária da ONG na qual atuava, e as cartas cessaram. Mas lembro aqui as palavras de Ana em sua carta "Olha, amiga, mesmo que nós não nos encontremos novamente, saiba que levarei você dentro do meu coração, e levarei comigo tudo que aprendi nos grupos, e algumas amizades que fiz neste lugar”. De fato, acredito que a força desses encontros e das experiências compartilhadas não se cederá tão rápida e facilmente. Este trabalho foi também uma forma de registrar e compartilhar a força da marca que os encontros deixaram em mim como psicóloga, pesquisadora e como pessoa. Assim, apesar do contexto dolorido e do ambiente inóspito e hostil de uma penitenciária, falo sim de saudades neste texto, delas e do que pudemos ser e sonhar juntas.

Compartilho por fim, a carta de Rosana, que não foi endereçada a mim pessoalmente, mas para todo o grupo no qual a autora participou durante o projeto, e foi lida para todas as presentes na ocasião do encerramento das atividades. Na esperança de outros encontros, lança-se mais este convite.

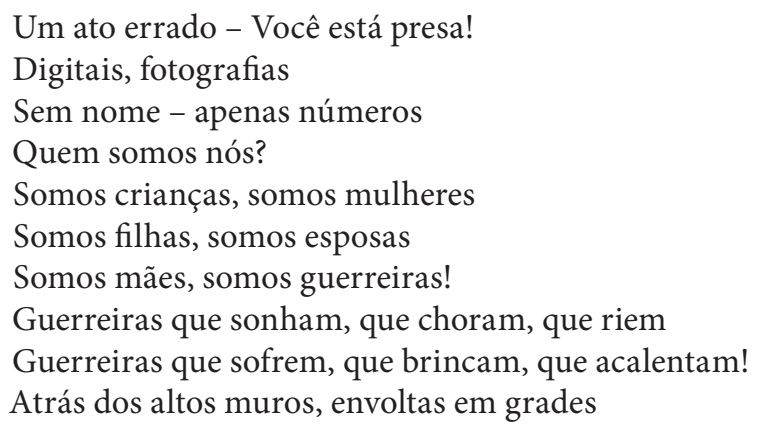


Longe da família, do lar, longe dos filhos

Das amigas sinceras, restaram as lembranças, as saudades

Pequenos detalhes que fazem a diferença.

Os dias que passam, cada qual com seus sentimentos, seus pensamentos Suas saudades, suas revoltas, suas vontades e suas vaidades

Mas, e quanto à sociedade? Se importará em saber quem somos nós?

Mas mesmo que não queiram, ainda assim o diremos!

Somos mães guerreiras!

Com direito a cidadania, dignidade e igualdade

Independente do lugar onde nos encontremos. 


\section{Referências}

AgAmben, G. Homo sacer - o poder soberano e a vida nua. Tradução de Henrique Burigo. Belo Horizonte: Editora UFMG, 2007.

ARENDT, H. A condição humana. 10 ${ }^{a}$ ed. Rio de Janeiro: Forense Universitária, 2008.

Sobre a Violência. Rio de Janeiro: Civilização Brasileira, 2009.

BARreto, N. A. No ventre da cadeia. Um estudo sobre os projetos futuros de mulheres encarceradas. 2006. Tese (Doutorado em Psicologia Clínica) -Pontifícia Universidade Católica do Rio de Janeiro, Rio de Janeiro, 2006.

BAUMAN, z. Globalização: as conseqüências humanas. Rio de Janeiro: Jorge Zahar, 1999.

Benjamin, w. Obras escolhidas. Vol.1. 7ª.ed. São Paulo: Ed. Brasiliense, 1994.

BONACCHI, G.; GROPPI, A., O dilema da cidadania: direitos e deveres das mulheres. São Paulo: Universidade Estadual Paulista, 1995.

BOSI, E. O tempo vivo da memória. 2a .ed. São Paulo: Ateliê Editorial, 2004.

Memória e sociedade. $14^{\mathrm{a}}$ ed. São Paulo: Ed. Schwarcz Ltda., 2007.

BRAUNSTEIN, H. R. Mulher encarcerada: trajetória entre a indignação e o sofrimento por atos de humilhação e violência. 2007. Dissertação (Mestrado em Educação) - Faculdade de Educação, Universidade de São Paulo, São Paulo, 2007.

BREYNER, S. M. A Hora. In: Dia do mar. Lisboa: Editora Ática, 1947.

Poesia. Lisboa: Editora Caminho, 2003.

busnardo, A. M. A memória da amizade. 2007. Dissertação (Mestrado em Psicologia) - Instituto de Psicologia, Universidade de São Paulo, São Paulo, 2007 .

CÁRCERE E A RUA, O. Direção: Liliana Sulzbach. Europa Filmes, 2005.

CLADEM (COMITÊ LATINO-AMERICANO E DO CARIBE PARA A DEFESA DOS DIREITOS DA MULHER). Relatório sobre mulheres encarceradas no Brasil. 2007. Disponível em: http://www.cladem.org/portugues/nacionais/brasil/Relatorio\%2osobre\%2omujeres\%2oencarceladas\%20-\%2oBrasil.pdf. Acesso em $03 / 11 / 2008$.

Concilio, v. Teatro e prisão: dilemas da liberdade artística. São Paulo: Hucitec, 2008. 
CosTA, M. L. Lévinas: uma introdução. Petrópolis: Vozes, 1999.

DE GIORGI, A. A miséria governada através do sistema penal. Rio de Janeiro: Revan, 2006.

depen (Departamento penitenciário nacional). Disponível em: http://www. mj.gov.br/depen. Acesso em: 03/11/ 2008.

FERREIRA, M. I. C. Violência na solidariedade: um estudo sobre homicídios em bairros da periferia da capital paulista. v. 1. São Paulo: Associação Editorial Humanitas, 2006.

fOUCAUlt, M. Vigiar e punir: história da violência nas prisões. São Paulo: Vozes, 1993.

Garland, D. Punishment and modern society: a study in social theory. Oxford: Claredon Press, 1995.

Goffman, E. Manicômios, prisões e conventos. São Paulo: Ed. Perspectiva, 1999.

GONÇALVES FILHO, J. M. Humilhação social - um problema político em psicologia. Psicologia USP, São Paulo, v. 9, n. 2, p. 11-67, 1998.

. Problemas de método em Psicologia Social: algumas notas sobre a humilhação política e o pesquisador participante. In: BосK, A. M. B. (org.) Psicologia e compromisso social. São Paulo: Cortez, 2003.

. Invisibilidade pública. Prefácio. In: costA, F. B. da. Homens invisíveis - relatos de uma humilhação social. São Paulo: Globo, 2004.

LEMgruber, J. Cemitério dos vivos: análise sociológica de uma prisão de mulheres. 2. ${ }^{a}$ ed. Rio de Janeiro: Editora Forense, 1999.

LOPES, R. Prisioneiras de uma mesma história: o amor materno atrás das grades. 2004. Tese (Doutorado em Psicologia) - Instituto de Psicologia, Universidade de São Paulo, São Paulo, 2004.

mamede, M. C. Cartas e retratos - uma clínica em direção à ética. Curitiba: Altamira, 2006.

MeIreles, C. Antologia poética. Rio de Janeiro: Editora Nova Fronteira, 2001.

MENegat, M. E.; NeRI, R. (org). Criminologia e subjetividade. Rio de Janeiro: Editora Lúmen Júris, 2005.

MOURA, T. Rostos invisíveis da violência armada: um estudo de caso sobre o Rio de Janeiro. Rio de Janeiro: 7Letras, 2007. 
NAJJAR, A. M. S. Raízes: como sobreviver sem a sua seiva? In: Catafesta, I. F. da M. (org.) A clínica e a pesquisa no final do século: Winnicott e a Universidade. São Paulo: Lemos Editorial, 1997.

. Quando o carteiro não chegou. In: Revista Insight Psicoterapia, São Paulo, Lemos Editorial, ano VIII, n. 89, p. 24-27, 1999.

Oliveira, P. S. Caminhos de construção das ciências humanas. In:

(org.). Metodologia das ciências humanas. $2^{\mathrm{a}}$ ed. São Paulo: Ed. Unesp, 1998.

. Vidas compartilhadas: cultura e co-educação de gerações na vida cotidiana. São Paulo: Ed. Hucitec/FAPESP, 1999.

PEDRO-SILVA, N. Entre o público e o privado: ensaio sobre o valor da lealdade à palavra empenhada na contemporaneidade. v. 1.São Paulo: Editora Unesp, 2007.

PELlegrino, H. Pacto edípico e pacto social. In: PY, L. A. (org.). Grupo sobre grupo. Rio de Janeiro: Editora Rocco, 1987.

PINSKY, J.; PINSKY, C. B. (org.). História da cidadania. $4^{\text {a }}$ ed. São Paulo: Ed. Contexto, 2003.

RICOEUR, P. Le temps et les philosophies. Paris: Payot/Unesp, 1978

rio de janeiro (estado). Superintendência de Saúde. Perfil biopsicossocial das pessoas condenadas que ingressaram no sistema penitenciário do estado do Rio de Janeiro: um estudo de cinco anos. Colaboração Universidade do Estado do Rio de Janeiro e Departamento Penitenciário Nacional. Rio de Janeiro: CNPCP/DEPEN/MJ, 2006.

ROCHA, L. C. Vidas presas: uma tentativa de compreender a tragédia da criminalidade junto às suas personagens oprimidas. 1984. Dissertação (Mestrado em Psicologia) - Instituto de Psicologia, Universidade de São Paulo, São Paulo, 1984.

. A prisão dos pobres. 1994. Tese (Doutorado em Psicologia) - Instituto de Psicologia, Universidade de São Paulo, São Paulo, 1994.

SAfFioti, H. I. B. Violência doméstica ou a lógica do galinheiro. In: Kupstas, M. (org.) Violência em debate. São Paulo: Moderna, 1997.

SAlla, F. As prisões em São Paulo. São Paulo: Annablume/Fapesp, 1999

SAFrA, G. A face estética do self. Teoria e clínica. São Paulo: Ed. Unimarco, 2005.

Sсотт, J. Gênero: uma categoria útil de análise histórica. In: Educação e realidade. Porto Alegre, n. 16, p. 5-22, jul./dez. 1990. 
SENNETT, R. A corrosão do caráter. Rio de Janeiro: Ed. Record, 2000.

SILVA, M. V. de O. Psicologia e direitos humanos: subjetividade e exclusão. São Paulo/Brasília: Casa do Psicólogo/Conselho Federal de Psicologia, 2004.

souzA, M. L. R. de. Violência. Clínica psicanalítica. São Paulo: Casa do Psicólogo, 2005 .

TELLES, v. S. Direitos sociais: afinal do que se trata? Belo Horizonte: Ed. UFMG, 2006.

Thoreau, H. D. A desobediência civil. Porto Alegre: Editora L\&PM, 2010.

WEIL, S. A condição operária: e outros estudos sobre a opressão. Rio de Janeiro: Ed. Paz e Terra, 1979. 